MLM-3806

UC-702

\title{
Mound Site Environmental Monitoring \\ Report for Calendar Year 1993
}

Prepared by the Environmental Technology and Monitoring Section.

Issued: August 1994

\section{MOUND}

operated by

EG\&E MOUND APPLIED TECHNOLOGIES

P.O. Box 3000, Miamisburg, Ohio 45343-3000

for the

U. S. DEPARTMENT OF ENERGY

Contract No. DE-AC04-88DP43495 


\section{DISCLAIMER}

This report was prepared as an account of work sponsored by an agency of the United States Government. Neither the United States Government nor any agency thereof, nor any of their employees, makes any warranty, express or implied, or assumes any legal liability or responsibility for the accuracy, completeness, or usefulness of any information, apparatus, product, or process disclosed, or represents that its use would not infringe privately owned rights. Reference herein to any specific commercial product, process, or service by trade name, trademark, manufacturer, or otherwise does not necessarily constitute or imply its endorsement, recommendation, or favoring by the United States Government or any agency thereof. The views and opinions of authors expressed herein do not necessarily state or reflect those of the United States Government or any agency thereof. 


\section{DISCLAIMER}

Portions of this document may be illegible in electronic image products. Images are produced from the best available original document. 


\section{TABLE OF CONTENTS}

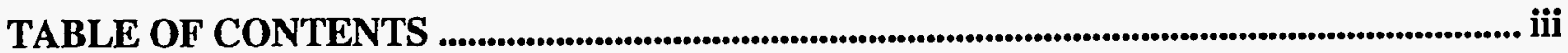

LIST OF FIGURES ...................................................................................................................... vii

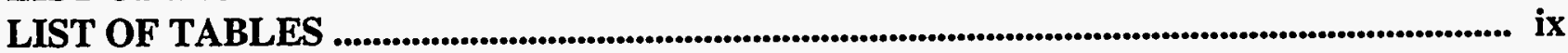

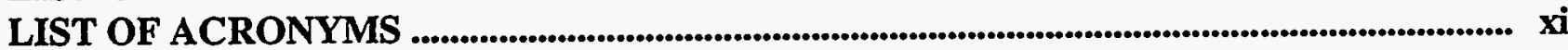

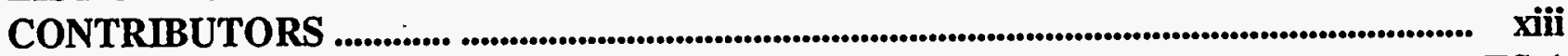

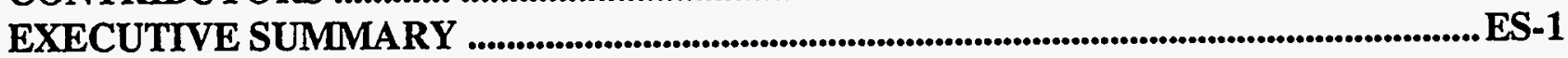

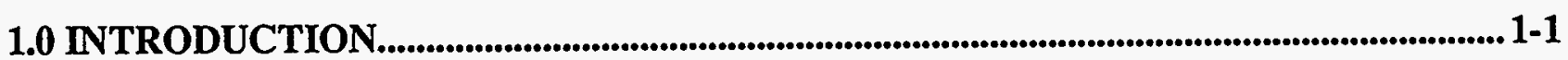

1.1 Description of Mound Site and Operations ................................................................. 1-1

Location ..................................................................................................................... 1-1

Population and Land Use .......................................................................................... 1-2

Climate ...................................................................................................... 1-4

Geology ............................................................................................................. 1-4

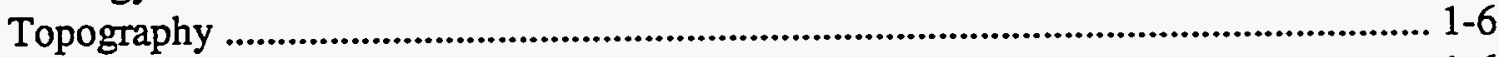

Mission and Operations .............................................................................................. 1-6

1.2 Perspective on Radiation ........................................................................................... 1-8

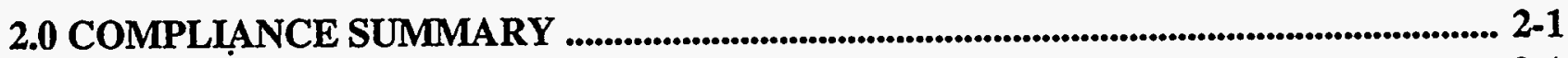

2.1 Major Environmental Statutes, Regulations, and Orders ................................................ 2-1

Clean Air Act ............................................................................................................ 2-1

Clean Water Act .......................................................................................................... 2-2

Safe Drinking Water Act .............................................................................................. 2-3

Resource Conservation and Recovery Act ..................................................................... 2-3

Toxic Substances Control Act ...................................................................................... 2-4

Comprehensive Environmental Response, Compensation, and Liability Act .............. 2-5

Emergency Planning and Community Right-to-Know Act (SARA Title III) .............. 2-6

National Environmental Policy Act ............................................................................... 2-6

Endangered Species Act ............................................................................................... 2-7

Federal Facilities Compliance Act ............................................................................... 2-7

Executive Order 11988, "Floodplain Management" ...................................................... 2-7

Executive Order 11990, "Protection of Wetlands" ........................................................ 2-7

2.2 Other Key Environmental Compliance Issues .................................................................... 2-7

Tiger Team Action Plan ........................................................................................... 2-7

Major External Environmental Audits in 1993 ............................................................ 2-8

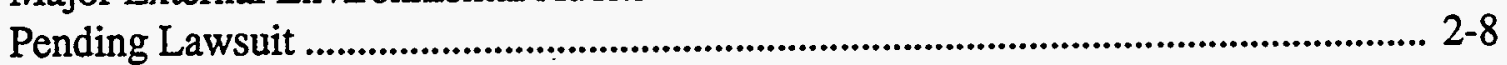

2.3 Summary of Permits ................................................................................................ 2-9 


\section{TABLE OF CONTENTS (Continued)}

3.0 ENVIRONMENTAL PROGRAM INFORMATION ........................................................... 3-1

3.1 Effluent Monitoring …............................................................................................... 3-1

Air Emissions ........................................................................................................ 3-1

Liquid Releases ............................................................................................. 3-1

3.2 Environmental Monitoring ............................................................................................ 3-1

Radionuclides of Concern ................................................................................ 3-1

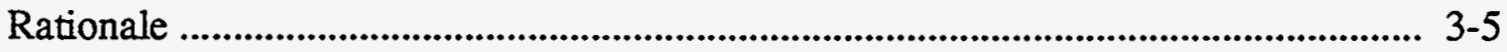

Environmental Levels ................................................................................... 3-5

3.3 Effluent Treatment and Waste Management ................................................................ 3-6

Effluent Treatment ........................................................................................ 3-6

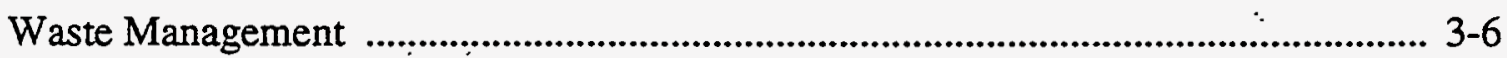

3.4 Environmental Permits ........................................................................................ 3-6

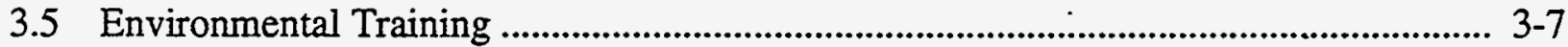

3.6 Waste Minimization and Pollution Prevention (WM/PP) ............................................... 3-7

3.7 Environmental Restoration (ER) ................................................................................... 3-9

Mound Plant Operable Units ......................................................................................... 3-9

ATSDR Participation ................................................................................................... 3-11

4.0 RADIOLOGICAL ENVIRONMENTAL PROGRAM INFORMATION ......................... 4-1

4.1 Radionuclides Releases from Mound .......................................................................... 4-1

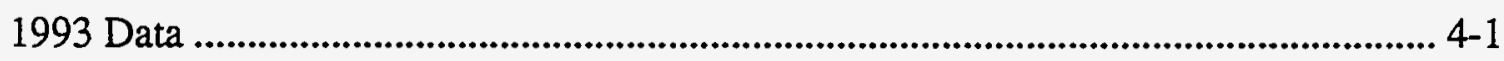

5-Year Trends in Radionuclide Releases ................................................................ 4-2

4.2 Effluent Monitoring Program ......................................................................................... 4-5

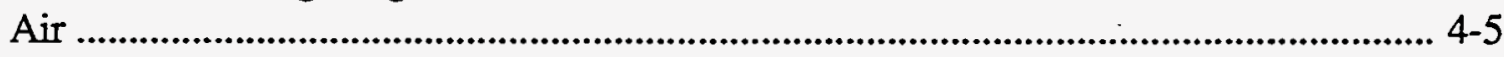

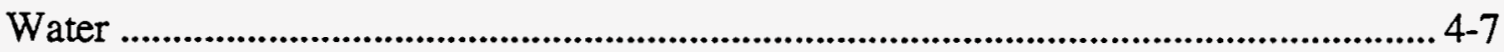

4.3 Environmental Surveillance .............................................................................. 4-7

Environmental Concentrations .......................................................................... 4-7

Lower Detection Limit ........................................................................................ 4-7

4.4 Air Sampling Program ......................................................................................... 4-7

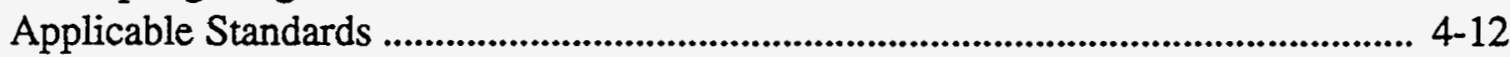

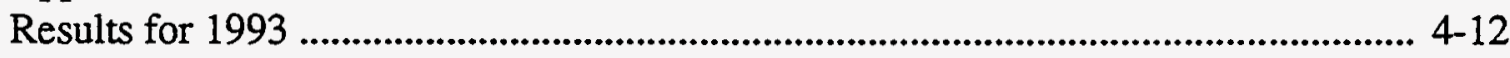

4.5 Surface Water and Sediment Sampling Program.............................................................. 4-12

Applicable Standards .............................................................................................. 4-17

Results for 1993 ..................................................................................................... 4-17

4.6 Produce and Vegetation .............................................................................. 4-25

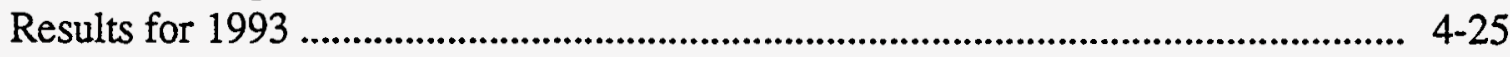

4.7 Offsite Dose Impacts ................................................................................................ 4-29

Dose Estimates Based on Measured Concentrations .................................................. 4-29

Dose Estimates for NESHAPs Compliance ............................................................. 4-30 


\section{TABLE OF CONTENTS (Continued)}

5.0 NONRADIOLOGICAL ENVIRONMENTAL PROGRAM INFORMATION.

5.1 Air Monitoring Program

5.2 Water Monitoring Program

NPDES Monitoring Requirements

Results

5.3 Submissions Under SARA Title III ........................................................................ 5-10

5.4 Environmental Occurrences ...................................................................................... 5-10

6.0 GROUNDWATER MONITORING PROGRAM.................................................................... 6-1

6.1 Regional Geohydrology ............................................................................................ 6-1

Uses of Groundwater in the Vicinity ....................................................................... 6-2

6.2 Hydrology at Mound ................................................................................................... 6-2

Aquifer Pump Test .................................................................................................. 6-3

Seeps .......................................................................................................... 6-8

Surface Water Features ............................................................................................... 6-9

6.3 Offsite Groundwater Monitoring Program ...................................................................... 6-9

Tritium in Production and Private Wells ..................................................................... 6-9

Tritium in Community Drinking Water Supplies .......................................................... 6-10

Tritium in Offsite Monitoring Wells .......................................................................... 6-10

Offsite Monitoring Activities for Other Radionuclides .............................................. 6-12

VOCs in Offsite Monitoring Wells .......................................................................... 6-14

6.4 Onsite Groundwater Monitoring Program .................................................................... 6-15

Tritium in Mound's Production Wells ....................................................................... 6-15

Tritium in the BVA ........................................................................................ 6-15

Tritium in the Seeps ................................................................................................ 6-17

Tritium in the Capture Pits .......................................................................................... 6-19

Onsite Monitoring Activities for Other Radionuclides ............................................... 6-20

VOC Monitoring Activities ....................................................................................... 6-22

6.5 Five-Year Trends for Wells of Interest .................................................................... 6-26

Trend Data for Offsite Drinking Water ....................................................................... 6-26

Trend Data for Onsite Production Wells and Seeps ................................................. 6-26

7.0 QUALITY ASSURANCE PROGRAMS FOR ENVIRONMETAL DATA ..................... 7-1

EML QA Program …...................................................................................................... 7-1

NPDES QA Program ......................................................................................................... 7-1

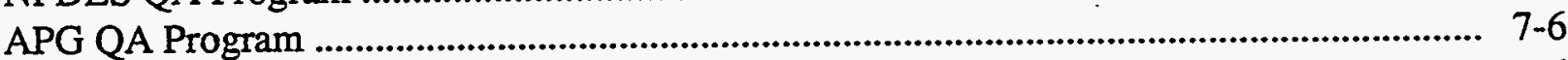

Mound QA Program ........................................................................................................... 7-6

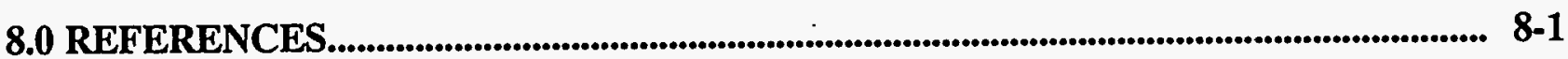

APPENDIX Dose Assessment Methodology …...................................................................... A-1 


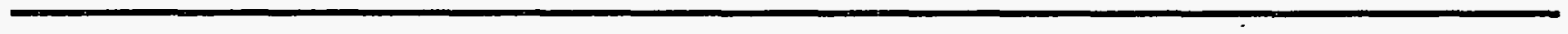

- 


\section{LIST OF FIGURES}

1-1. Locations of the Mound Plant and Surrounding Communities ..........................................1-1

1-2. Location of the Mound Plant .......................................................................................... 1-2

1-3. Distribution of the Population within $50 \mathrm{mi}(80 \mathrm{~km})$ of Mound ...................................... 1-3

1-4. Monthly Rainfall Measured at Mound in 1993 ................................................................. 1-4

1-5. 1993 Wind Rose for the Mound Plant .............................................................................. 1-5

1-6. Mound Site Topography ............................................................................................ 1-7

1-7. Average Annual Radiation Dose in the U.S. (NCRP, 1987) ............................................ 1-10

3-1. Organizational Structure of Mound's Waste Minimization Program ................................ 3-8

3-2. Mound Plant Operable Unit Boundaries .......................................................................... 3-10

4-1. Tritium Releases from Mound to the Atmosphere, 1989 - 1993 ...................................... 4-2

4-2. Tritium Releases from Mound to the Great Miami River, 1989 - 1993 ............................ 4-3

4-3. Plutonium-238" Releases from Mound to the Atmosphere, 1989 - 1993 ............................ 4-3

4-4. Plutonium-238 Releases from Mound to the Great Miami River, 1989 - 1993 .................. 4-4

4-5. Plutonium-239,240 Releases from Mound to the Atmosphere, 1989 - 1993 ......................4-4

4-6. Plutonium-239,240 Releases from Mound to the Great Miami River, 1989 - 1993 ............4-5

4-7. Uranium Releases from Mound to the Atmosphere, 1989 - 1993 ...................................... 4-6

4-8. Uranium-233,234 Releases from Mound to the Great Miami River, 1989 - 1993 ............ 4-6

4-9. Liquid Effluent Sampling Locations for Radionuclides ..................................................... 4-8

4-10. Onsite Air Sampling Locations ...................................................................................... 4-10

4-11. Offsite Air Sampling Locations ........................................................................................ 4-11

4-12. Sampling Locations for River Water, Ponds, and Sediment .............................................. 4-16

4-13. Exposure Pathways for Dose Calculations Based on Measured Data for 1993 .............. 4-29

$5.1 \quad$ NPDES Sampling Locations ......................................................................................... 5-4

5.2 NPDES Sampling Profile for the Five-Year Period 1989 - 1993 ..................................... 5-8

6.1 Location and Extent of the Buried Valley Aquifer .............................................................. 6-1

6.2 Production and Monitoring Well Locations ........................................................................ 6-4

6.3 Mound Plant Groundwater Level Elevations .................................................................... 6-6

6.4 Trichloroethene Concentrations During the Time Series Sampling .................................. 6-3

6.5 Geologic Cutaway of the Mound Plant ................................................................................ 6-8

6.6 Seep and Capture Pit Sampling Locations ……............................................................... 6-18

6.7. Average Annual Tritium Concentration in Offsite Drinking Water, 1989 - 1993 ........... 6-27

6.8 Average Annual Tritium Concentration in Onsite Drinking Water, 1989 - 1993 ............ 6-27

6.9 Average Annual Indicator VOC Concentration in Onsite Drinking Water,

6.10 Average Annual Tritium Concentration for Seep 0601, 1989 - 1993 ............................... 6-29

6.11 Average Annual Indicator VOC Concentration for Seep 0601, 1989 - 1993 .................. 6-29 


\section{LIST OF FIGURES (Continued)}

7.1 Mound's Performance in the DOE Quality Assurance Program in 1993 ..................... 7-3

7.2a Mound's Performance in the APG Proficiency Environmental Testing Program for 1993: Trace Metal Analysis ..................................................................................... 7-7

7.2b Mound's Performance in the APG Proficiency Environmental Testing Program for 1993: Miscellaneous Parameters 


\section{LIST OF TABLES}

E-1. Radiological Effluent Data for 1993 ...................................................................... ES-2

E-2. Radiation Dose Limits for Protection of the Public from All Routine

DOE Operations

E-3. Maximum Committed Effective Dose Equivalents to a Hypothetical

Individual in 1993

1.1 Population Totals from the 1990 Census .................................................................. 1-2

1-2. Percent Frequency of Wind Direction and Wind Speed from the Mound Plant 50-m Meteorological Tower for 1993

3-1. Effluent Monitoring at Mound.

3-2. Environmental Surveillance at Mound. $3-4$

3-3. Environmental Permits Issued to Mound . 3-7

4-1. Radiological Effluent Data for 1993

4-2. Environmental Concentrations of Radionuclides in Sample Media in 1993.

4-3. Incremental Concentrations of Tritium Oxide in Air in 1993

4-4. Incremental Concentrations of Plutonium-238 in Air in 1993 4-14

4-5. Incremental Concentrations of Plutonium-239, 240 in Air in 1993 4-15

4-6. Concentrations of Tritium in the Great Miami River in 1993 4-18

4-7. Concentrations of Plutonium-238 in the Great Miami River in 1993 ............................. 4-18

4-8. Concentrations of Plutonium-239,240 in the Great Miami River in 1993........................ 4-19

4-9. Incremental Concentrations of Uranium-233,234 and Uranium-238 in the Great Miami River in 1993

4-10. Incremental Concentrations of Tritium in Pond Water in 1993 $4-21$

4-11. Incremental Concentrations of Plutonium-238 in Pond Water in 1993 4-21

4-12. Incremental Concentrations of Plutonium-239, 240 in Pond Water in 1993. 4-22

4-13. Incremental Concentrations of Plutonium-238 in River and Pond Sediments in 1993 .. 4-23

4-14. Incremental Concentrations of Plutonium-239,240 in River and Pond Sediments in 1993

4-15. Incremental Concentrations of Tritium in Vegetation and Produce in 1993 ..................... 4-26

4-16. Concentrations of Plutonium-238 in Vegetation and Produce in 1993 .......................... 4-27

4-17. Concentrations of Plutonium-239,240 in Vegetation and Produce in 1993 ..................... 4-28

4-18. Maximum Committed Effective Dose Equivalents to a Hypothetical Individual in 1993 


\section{LIST OF TABLES (Continued)}

5-1. Nonradiological Airborne Effluent Data for 1993 ............................................................. 5-1

5-2. 1993 Particulate Concentrations ....................................................................... 5-2

5-3. National Pollution Discharge Elimination System Data for 1993 .................................... 5-5

5-4. Summary of Organic Compounds Detected in Mound Effluents in 1993 ......................... 5-9

5-5. 1993 Emergency and Hazardous Chemical Data for Mound ............................................ 5-10

6-1. Tritium Concentrations in Offsite Production and Private Wells in 1993 ......................... 6-9

6-2. Tritium Concentrations in Community Drinking Water Supplies in 1993 ....................... 6-10

6-3. Tritium Concentrations in Offsite Monitoring Wells in 1993 .......................................... 6-11

6-4. Plutonium Concentrations in Offsite Drinking Water and an Offsite Private

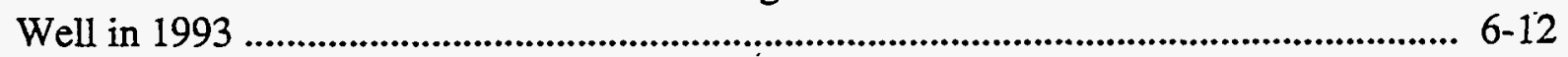

6-5. Uranium Concentrations in Offsite Drinking Water and an Offsite Private Well in 1993 ............................................................................................................... 6-13

6-6. VOC Concentrations in Offsite Monitoring Wells in 1993 ......................................... 6-14

6-7. Tritium Concentrations in Onsite Productions Wells in 1993 ......................................... 6-15

6-8. Tritium Concentrations in Onsite Monitoring Wells in 1993 .......................................... 6-16

6-9. Tritium Concentrations in Seeps in 1993 ...................................................................... 6-17

6-10. Tritium Concentrations in the Capture Pits in 1993 ....................................................... 6-19

6-11. Plutonium Concentrations in Onsite Production Wells in 1993 ........................................ 6-20

6-12. Uranium Concentrations in Onsite Production Wells in 1993 ......................................... 6-21

6-13. VOC Concentrations in Onsite Production Wells in 1993 .............................................. 6-22

6-14. VOC Concentrations in Onsite Monitoring Wells in 1993 .............................................. 6-23

7-1. Mound DOE Quality Assessment Program Results for 1993: Radionuclides in Environmental Samples .................................................................................................... 7-2

7-2. Mound's Performance in the NPDES Quality Assurance Program for 1993 ..................... 7-4

A-1. Factors Used to Calculate 1993 CEDEs ...................................................................... A-2

A-2. 1993 CAP-88 Input Data .......................................................................................... A-3 


\section{LIST OF ACRONYMS}

\begin{tabular}{ll} 
AIL & ALARA Investigation Level \\
A-I-P & Agreement-In-Principle \\
ALARA & As Low As Reasonably Achievable \\
APG & Analytical Products Group, Inc. \\
ARARs & Applicable or Relevant and Appropriate Requirements \\
ATSDR & Agency for Toxic Substances and Disease Registry \\
BOD & Biological Oxygen Demand \\
BVA & Buried Valley Aquifer \\
CAA & Clean Air Act \\
CBOD & Carbonaceous Biochemical Oxygen Demand \\
CEDE & Committed Effective Dose Equivalent \\
CERCLA & Comprehensive Environmental Response, Compensation, and Liability Act \\
CFC & Chlorinated Fluorocarbons \\
CFR & Code of Federal Regulations \\
COD & Chemical Oxygen Demand \\
CWA & Clean Water Act \\
DAO & Dayton Area Office \\
DCG & Derived Concentration Guide \\
D\&D & Decommissioning and Decontamination \\
DNFSB & Defense Nuclear Facilities Safety Board \\
DOE & U.S. Department of Energy \\
DWS & Drinking Water Standard \\
EA & Environmental Assessment \\
EDE & Effective Dose Equivalent \\
EML & Environmental Measurements Laboratory \\
EPA & U.S. Environmental Protection Agency \\
ER & Environmental Restoration \\
ESA & Endangered Species Act \\
ES\&H & Environment, Safety, and Health \\
FFA & Federal Facility Agreement \\
FFCA & Federal Facility Compliance Agreement or Act \\
FIFRA & Federal Insecticide, Fungicide, and Rodenticide Act \\
FONSI & Finding of No Significant Impact \\
FWPCA & Federal Water Pollution Control Act \\
GPD & Gallons per Day \\
HEPA & High efficiency particulate air \\
HSWA & Hazardous and Solid Waste Amendments \\
HT & Tritium, elemental \\
HTO & Tritium, oxide \\
LDL & Lower Detection Limit \\
LSA & Low Specific Activity \\
& \\
\hline
\end{tabular}




\section{LIST OF ACRONYMS (Continued)}

$\begin{array}{ll}\text { MCL } & \text { Maximum Contaminant Level } \\ \text { MDL } & \text { Method Detection Limit } \\ \text { MGD } & \text { Million Gallons per Day } \\ \text { MRC } & \text { Monsanto Research Corporation } \\ \text { NEPA } & \text { National Environmental Policy Act } \\ \text { NESHAPs } & \text { National Emission Standards for Hazardous Air Pollutants } \\ \text { NPDES } & \text { National Pollutant Discharge Elimination System } \\ \text { NPL } & \text { National Priorities List } \\ \text { NTS } & \text { Nevada Test Site } \\ \text { NVO } & \text { Nevada Operations Office of the U.S. DOE } \\ \text { OAC } & \text { Ohio Administrative Code } \\ \text { OEPA } & \text { Ohio Environmental Protection Agency } \\ \text { OU } & \text { Operable Unit } \\ \text { PCBs } & \text { Polychlorinated Biphenyls } \\ \text { PWA } & \text { Process Waste Assessment } \\ \text { QA } & \text { Quality Assurance } \\ \text { RAPCA } & \text { Regional Air Pollution Control Agency } \\ \text { RCRA } & \text { Resource Conservation and Recovery Act } \\ \text { RI/FS } & \text { Remedial Investigation/Feasibility Study } \\ \text { RIR } & \text { Remedial Investigation Report } \\ \text { RMMAs } & \text { Radioactive Materials Management Areas } \\ \text { RQ } & \text { Reportable Quantity } \\ \text { SARA } & \text { Superfund Amendments and Reauthorization Act } \\ \text { SDWA } & \text { Safe Drinking Water Act } \\ \text { TSCA } & \text { Toxic Substances Control Act } \\ \text { TTOs } & \text { Total Toxic Organics } \\ \text { UST } & \text { : Underground Storage Tank } \\ \text { VOCs } & \text { Volatile organic compounds } \\ \text { WM/PP } & \text { Waste minimization / Pollution prevention } \\ & \end{array}$




\section{CONTRIBUTORS}

This report report was prepared by L.R. Bauer, B.M. Farmer, R.P. Paulick, J.R. Hausfeld, and L.L. Roush of the Environmental Technology \& Monitoring Section of EG\&G Mound Applied Technologies. The authors note with appreciation the support of the following EG\&G Mound Applied Technologies personnel:

R.J. Brewer

B.C. Dellaposta

A. Gibson

S.L. Goforth

T.J. Hamilton

L.C. Hopkins
S.L. Howard

V.S. Johnson

C. Kinard

D.L. McCormick

Mound Printing Services Staff

C.A. Phillips
D.E. Poteet

J.K. Puckett

M.J. Sellers

M.S. Tullis

J.M. Walker

M.G. Wilson 


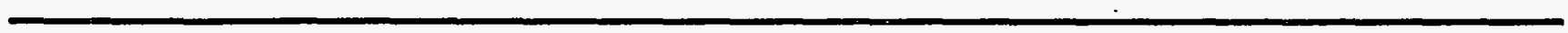




\section{EXECUTIVE SUMMARY}

The purpose of this report is to inform the public about the impact of Mound operations on the population and the environment. Mound is a government-owned facility operated by EG\&G Mound Applied Technologies for the U.S. Department of Energy (DOE). This integrated production, development, and research site performs work in support of DOE's weapon and energy related programs, with emphasis on explosive, nuclear and energy technologies.

The Mound Plant, named after the Miamisburg Indian Mound adjacent to the site, comprises 120 buildings on 124 hectares (306 acres) of land in Miamisburg, Ohio, approximately $16 \mathrm{~km}$ (10 mi) southwest of Dayton. The Great Miami River, which flows through the city of Miamisburg, dominates the landscape of the five-county region surrounding Mound. The river valley is highly industrialized. The rest of the region is predominately farm land dotted with light industry and small communities. The climate is moderate. The geologic record preserved in the rocks underlying Mound indicates that the area has been relatively stable since the beginning of the Paleozoic Era more than 500 million years ago. No buildings at Mound are located in a floodplain or in areas considered wetlands.

\section{ES.1 Perspective on Radiation}

Radionuclides, radioactive species of atoms, emit ionizing radiation. Ionizing radiation is radiation possessing enough energy to remove electrons from the substances through which it passes. Most consequences to humans from exposure to radionuclides arise from the interactions of ionizing radiation with human tissue. These interactions are measured based on the amount of energy deposited in the tissue. This value is the absorbed dose. Since different types of ionizing radiation cause different degrees of biological harm, it is necessary to weight doses to account for those differences. The unit used to make this comparison possible is the dose equivalent. The units used to report dose equivalents are the rem and the Sievert (Sv). Because doses associated with environmental exposures are typically only fractions of a rem or Sievert, it is common to report doses in terms of millirems (mrem) or millisieverts (mSv). There are 1000 mrem per rem; $1000 \mathrm{mSv}$ per Sv.
Our bodies are exposed to ionizing radiation each day. Most of this radiation comes from natural sources. The average dose to a resident of the United States from natural sources is about 300 mrem ( $3 \mathrm{mSv}$ ) per year. The primary contributors to this average dose are radon, cosmic and terrestrial sources, and medical sources such as $\mathrm{x}$ rays or other diagnostic exposures.

\section{ES.2 Radionuclide Releases from Mound}

Table E-1 lists the quantities of radionuclides released by Mound into the air and water during 1993. The unit used to report these quantities is the curie (Ci), a unit of radioactivity equal to 3.7 $\mathrm{x} 10^{10}$ disintegrations per second. The quantities, or activities, shown in Table E-1 were measured at the point of release. 
Table E-1. Radiological Effluent Data for 1993

\begin{tabular}{lcc}
\hline Radionuclide & Released to & Activity, Ci \\
\hline Tritium & Air & $664^{\mathrm{a}}$ \\
& Water & 3.4 \\
Plutonium-238 & Air & $1.2 \times 10^{-5}$ \\
& Water & $2.5 \times 10^{-4}$ \\
Plutonium-239,240 & Air & $4.0 \times 10^{-8}$ \\
& Water & $8.9 \times 10^{-6}$ \\
Radon-222 & Air & $1.1 \times 10^{-0}$ \\
Uranium-233,234 & Air & $6.3 \times 10^{-8}$ \\
& Water & $3.5 \times 10^{-4}$ \\
Uranium-238 & Air & $5.7 \times 10^{-8}$ \\
\hline \multirow{2}{*}{ aTritium in air consists of: } & Tritium oxide, 522 Ci \\
& Elemental tritium, $142 \mathrm{Ci}$ & \\
\hline
\end{tabular}

\section{ES.3 Dose Limits}

Dose limits, or more precisely, dose equivalent limits, for members of the public are presented in Table E-2. These limits are expressed in terms of a committed effective dose equivalent (CEDE) and an effective dose equivalent (EDE) for the DOE and U.S. Environmental Protection Agency (EPA), respectively. Values shown in Table E-2 represent annual limits on dose equivalents established by the DOE and EPA.

\section{ES.4 Doses from Mound Operations}

In calculating the maximum dose received by a member of the public from Mound operation;, a committed effective dose equivalent is used. The CEDEs are the doses received by a hypothetical individual who remained at the site boundary 24 hours per day throughout 1993. This individual was assumed to have:
- breathed only air containing the highest average radionuclide concentrations measured at an onsite air sampling station,

- drawn all of his drinking water from the offsite well with the highest average radionuclide concentration, and

- consumed produce exhibiting the concentrations measured in the samples collected from the Miamisburg area.

The CEDEs from all of these pathways are added to obtain an estimate of a maximum CEDE received by this hypothetical individual. Table E-3 shows the results for Mound in 1993. The results are reported for tritium, plutonium-238, and plutonium-239. The absence of a radionuclide, or an exposure pathway, from Table E-3 indicates that the 1993 concentrations were below background levels or were too small to affect the overall doses reported in the table. 
Table E-2. Radiation Dose Limits for Protection of the Public from All Routine DOE Operations

\begin{tabular}{|c|c|c|c|c|}
\hline & Pathway & $\begin{array}{l}\text { Regulatory } \\
\text { Standard }\end{array}$ & \multicolumn{2}{|c|}{$\begin{array}{c}\text { Effective } \\
\text { Dose Equivalenta }\end{array}$} \\
\hline \multirow[t]{3}{*}{$\cdot}$. & All exposure media & DOE Order 5400.5 & 100 & 1 \\
\hline & Air & 40 CFR 61 (EPA) & 10 & 0.1 \\
\hline & Drinking water & 40 CFR 141 (EPA) & 4 & 0.04 \\
\hline
\end{tabular}

a Evaluated based on annual exposure conditions.

Table E-3. Maximum Committed Effective Dose Equivalents to a Hypothetical Individual in 1993

\begin{tabular}{llll}
\hline Radionuclide & Pathway & mrem & $\mathrm{mSv}$ \\
\hline \multirow{2}{*}{ Tritium } & Air & 0.005 & 0.00005 \\
& Water & 0.04 & 0.0004 \\
& Produce & 0.004 & 0.00004 \\
\cline { 2 - 3 } Plutonium-238 & Total & 0.05 & 0.0005 \\
& Air & 0.13 & 0.0013 \\
& Produce & 0.07 & 0.0007 \\
\cline { 2 - 3 } Plutonium-239 & Total & 0.20 & 0.002 \\
& Air & 0.005 & 0.00005 \\
& Produce & 0.009 & 0.00009 \\
\hline & Total & 0.01 & 0.0001 \\
& & & \\
Total & & 0.26 & 0.0026 \\
\hline
\end{tabular}


The data presented in Table E-3 were calculated using environmental monitoring data measured on and near Mound. Mound also evaluates doses using the EPA's computer code CAP-88. CAP-88 uses air effluent data as input to transport, dispersion, and dosimetry codes. By executing these codes, one generates an estimate of a maximum offsite dose from airborne releases. For 1993, the CAP-88-estimated maximum offsite dose was 0.04 mrem. As reported in Table E-2, the EPA's annual dose limit for airborne releases is 10 mrem. Therefore, Mound's releases in 1993 represented $0.4 \%$ of the dose limit set by the EPA.

CAP-88 also estimates doses to populations surrounding Mound. The population (approximately 3,035,000 persons) within a radius of $80 \mathrm{~km}(50 \mathrm{mi})$ of Mound received an estimated 2.1 person-rem from Mound operations in 1993. CAP-88 arrived at that value first by calculating doses at specific distances, and in specific compass sectors, relative to Mound. The computer code then multiplied the average dose in a given area by the number of people living there. For example, an average dose of $0.001 \mathrm{rem} \times 10,000$ people in the area yields a collective dose of 10 person-rem. CAP-88 then sums up all the collective doses for the $80-\mathrm{km}$ radius region and reports a single number.

Since the average dose received each year by an individual is about $300 \mathrm{mrem}$, the collective background dose for the $80-\mathrm{km}$ population is approximately one million person-rem $(0.3 \mathrm{rem} x$ $3,035,000$ persons). Mound's contribution of 2.1 person-rem represents on the order of $0.00021 \%$ of the background value.

\section{ES.5 Environmental Monitoring Program Results}

Besides setting limits on the CEDE to any member of the public, DOE has established Derived Concentration Guides (DCGs) for individual radionuclides. The DCG is defined as the concentration of a radionuclide that will result in a CEDE of 100 mrem ( $1 \mathrm{mSv}$ ) following continuous exposure for one year. The concentrations of radionuclides resulting from Mound's 1993 releases were small fractions of the appropriate DCGs.

\section{Radiological Monitoring of the Atmosphere}

Ambient air is sampled for tritium and plutonium by an onsite network of seven perimeter stations and by an offsite network of 15 stations. Ten of the offsite samplers are located in the Miamisburg area. One sampler is located far enough away to receive virtually no impact from Mound operations. This sampler serves as a reference location to establish background levels of tritium and plutonium. The amount by which a sample exceeds the background or environmental level is reported as an incremental concentration.

Incremental concentrations measured at the onsite samplers were $0.003 \%$ and $0.04 \%$, respectively, of the DOEDCGs for tritium and plutonium-238. Average incremental concentrations at the offsite samplers for tritium and plutonium-238 were $0.001 \%$ and $0.008 \%$, respectively of the DOE DCGs. Incremental plutonium-239 concentrations averaged $0.003 \%$ and $0.0006 \%$ of the DOE DCGs for the onsite and offsite stations, respectively. 


\section{Radiological Monitoring of Water}

Water samples were collected from locations along the banks of the Great Miami River and were analyzed for tritium, plutonium-238, plutonium-239,240, uranium-233,234, and uranium-238. Other surface water locations were sampled for tritium and plutonium. Additionally, both river and pond sediment samples were collected and analyzed for plutonium.

River water. The average incremental concentrations of plutonium-238 and plutonium239 in water from the Great Miami River were $0.001 \%$ and $0.0008 \%$ of the DOE DCGs, respectively. Concentrations of uranium-233,234 and uranium-238 averaged $0.007 \%$ of their respective DCGs. Conversely, average tritium concentrations in the river were below environmental levels.

Sediment. Average concentrations of plutonium238 in sediment samples collected from the Great Miami River suggest some accumulation of Pu238 relative to other sampling locations. However, at such low concentrations, the error limits are - quite large and the potential risks are quite small.

\section{Radiological Monitoring of Produce and Vegetation}

Locally-grown foodstuffs, vegetation, and fish samples were collected from the surrounding area. These samples were then analyzed for tritium and/or plutonium as appropriate. Concentrations of tritium in vegetation and tomatoes were at or below environmental levels in most cases. Similar results were observed for concentrations of plutonium- 238 and plutonium239 in vegetation, root crops, and fish.

\section{Nonradiological Monitoring of Air}

Particulate loadings are measured at all of the onsite and offsite air sampling locations. Particulate concentrations appeared to be independent of distance. This result suggests Mound exerts little or no influence on the levels of airborne particulates.

\section{Nonradiological Monitoring of Water}

Mound's nonradiological liquid discharges are regulated by a National Pollutant Discharge Elimination System (NPDES) permit. In 1993, 1574 samples were collected to demonstrate compliance with the NPDES permit. One exceedance did occur. On August5, 1993, Mound exceeded the daily permit limit for chlorine. Mound recorded a chlorine concentration of 0.76 $\mathrm{mg} / \mathrm{L}$; the permit limit is $0.5 \mathrm{mg} / \mathrm{L}$.

\section{ES.6 Groundwater Monitoring Program}

Mound maintains an extensive network of onsite and offsite monitoring wells. In addition, a number of onsite and offsite production wells and drinking water systems are routinely monitored. Drinking water from the Miamisburg area is analyzed for tritium, plutonium, and uranium. Other regional water supplied are sampled for tritium. Samples from monitoring and production wells are analyzed for various constituents including volatile organic compounds, polychlorinated biphenyls, metals, and inorganic cations and anions. Monitoring data collected in 1993 indicate that volatile organic compounds and tritium, respectively, are the primary nonradiological and radiological contaminants of concern. 


\section{ES.7 Environmental Restoration Program}

Mound was designated a Superfund site, i.e., placed on the National Priorities List, in November of 1989. \& Federal Facilities Agreement (FFA) between the DOE and the U.S. EPA followed in October of 1990 . The FFA was expanded to a triparty agreement in 1993 when the Ohio EPA became a signatory. The purpose of the FFA remains unchanged; it defines the responsibilities of each party for the completion of Superfundrelated (CERCLA-related) activities.

Preliminary CERCLA assessments of contamination at Mound have identified approximately 125 locations of known or suspected releases. In .1993, comprehensive evaluations of these areas continued.

\section{ES.8 Quality Assurance for Environmental Data}

To ensure the reliability of environmental data, Mound maintains an internal quality assurance (QA) program that consists of running blanks, internal standards, and duplicate samples. Mound also participates in comparison exercises with external laboratories to validate further Mound's environmental results. Comparisons of Mound's performance with that of other laboratories are shown in Chapter 7 of this report. The close agreement between Mound and the external labs demonstrates that Mound's Environmental Monitoring Program generates reliable data. 


\subsection{INTRODUCTION}

\subsection{Description of Mound Plant}

\section{Location}

The Mound Plant, named after the Miamisburg Indian Mound adjacent to the site, comprises 120 buildings on 124 hectares (306 acres) of land in Miamisburg, Ohio, approximately $16 \mathrm{~km}(10 \mathrm{mi})$ southwest of Dayton (Figure 1-1). The Great Miami River, which flows southwest through the city of Miamisburg, dominates the geography of the five-county region surrounding Mound (Figure 1-2). The river valley is highly industrialized. The rest of the region is predominantly farmiand, dotted with light industry and smail communities.

Figure 1-1. Locations of the Mound Plant and Surrounding Communities

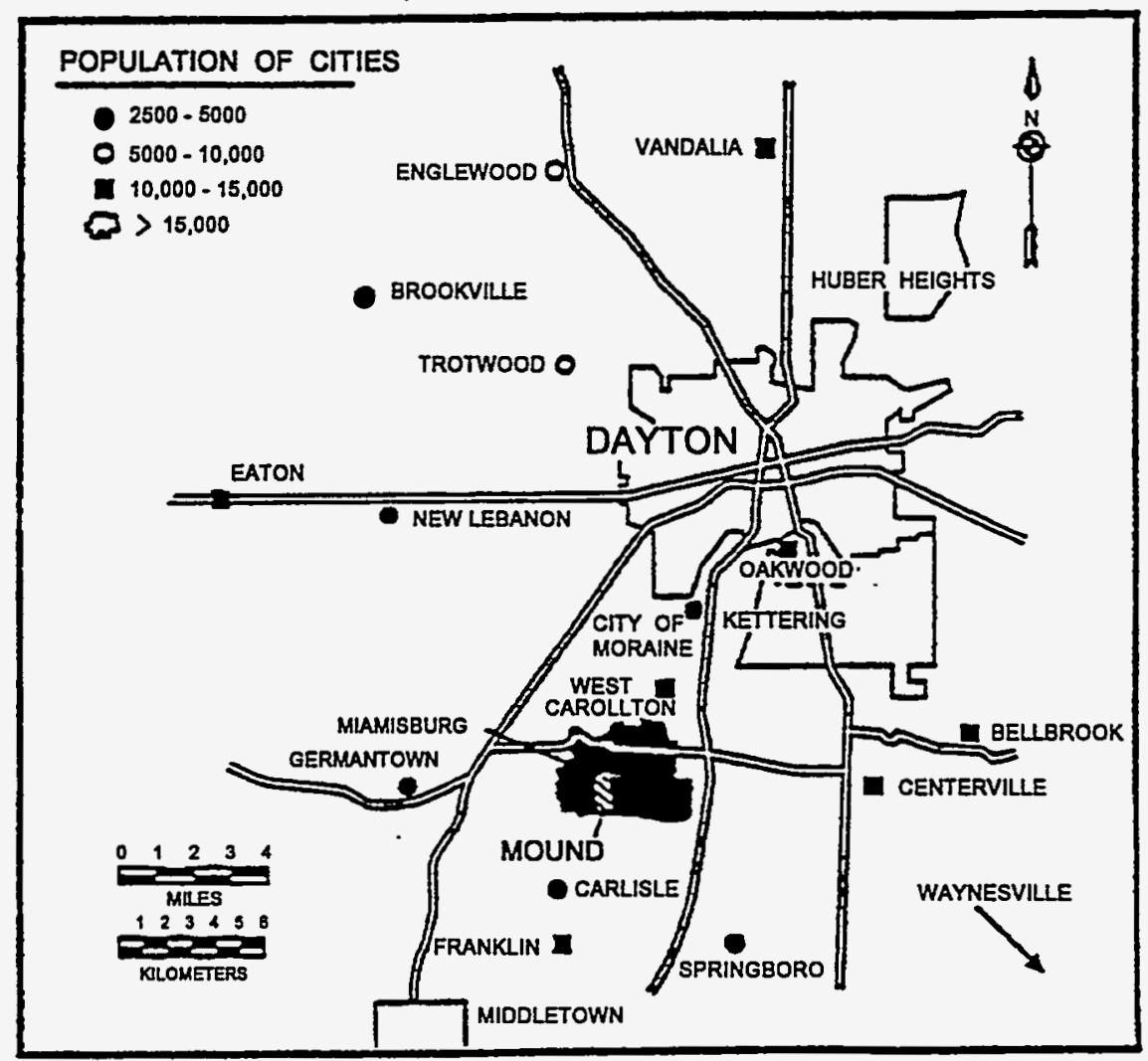


Figure 1-2. Location of the Mound Plant

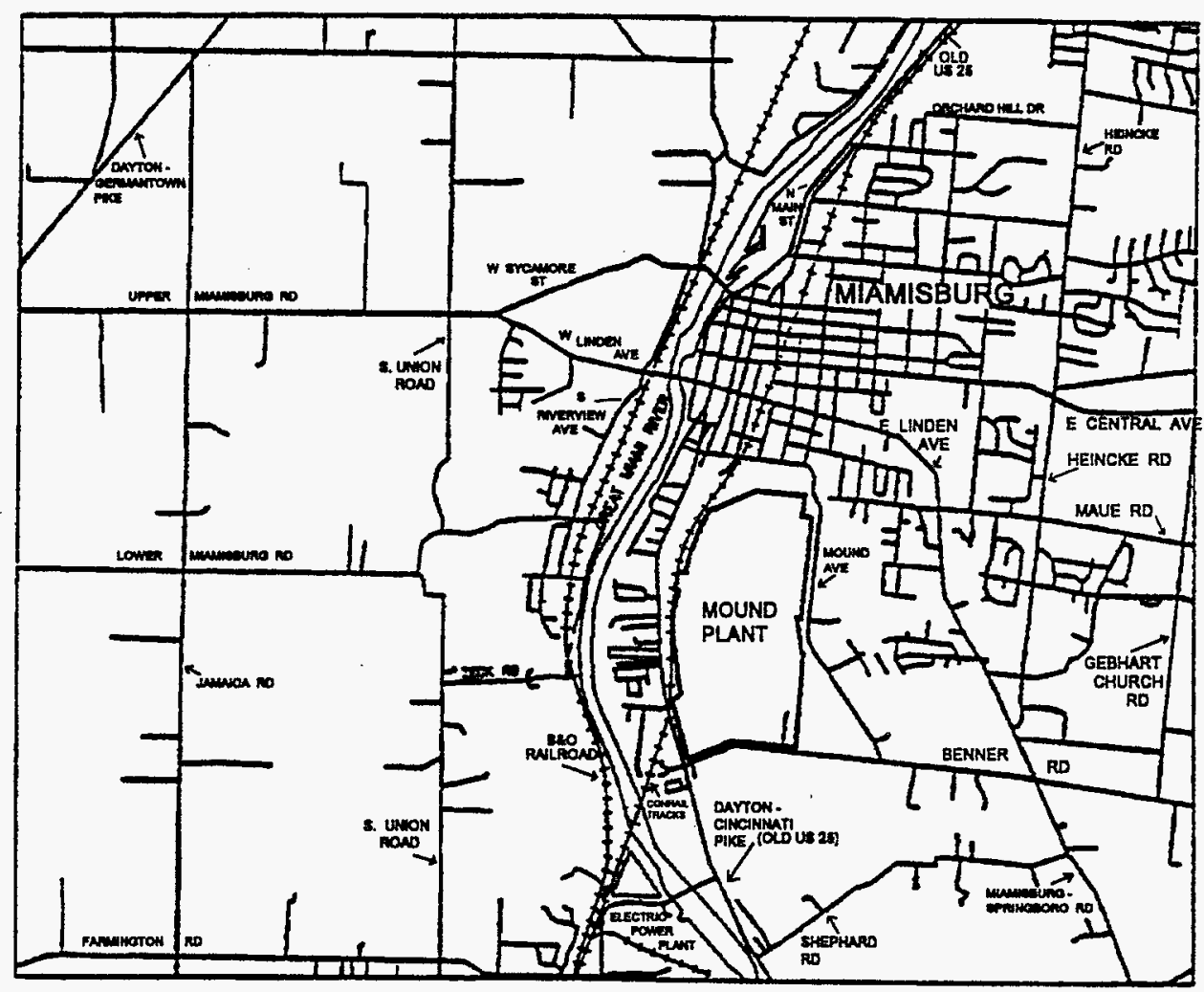

\section{Population and Land Use}

Figure 1-3 shows the population distribution within 50 miles $(80 \mathrm{~km})$ of Mound. The population information was extracted from 1990 Census data (PL94-171) by the Ohio Department of Development. The estimated number of individuals residing within the 50 -mile radius is 3,034,679 (Table 1-1).

The primary agricultural activity in the area is raising field crops such as corn and soybeans. Approximately $10 \%$ of the agricultural land is devoted to pasturing livestock.
Table 1-1. Population Totals from the 1990 Census

\begin{tabular}{cc}
\hline Radius, miles & \multicolumn{1}{c}{ Total } \\
\hline $0-10$ & 322,876 \\
$0-20$ & 887,114 \\
$0-30$ & $1,477,621$ \\
$0-40$ & $2,541,609$ \\
$0-50$ & $3,034,679$ \\
\hline
\end{tabular}


Figure 1-3. Distribution of Population within $50 \mathrm{mi}(80 \mathrm{~km})$ of Mound

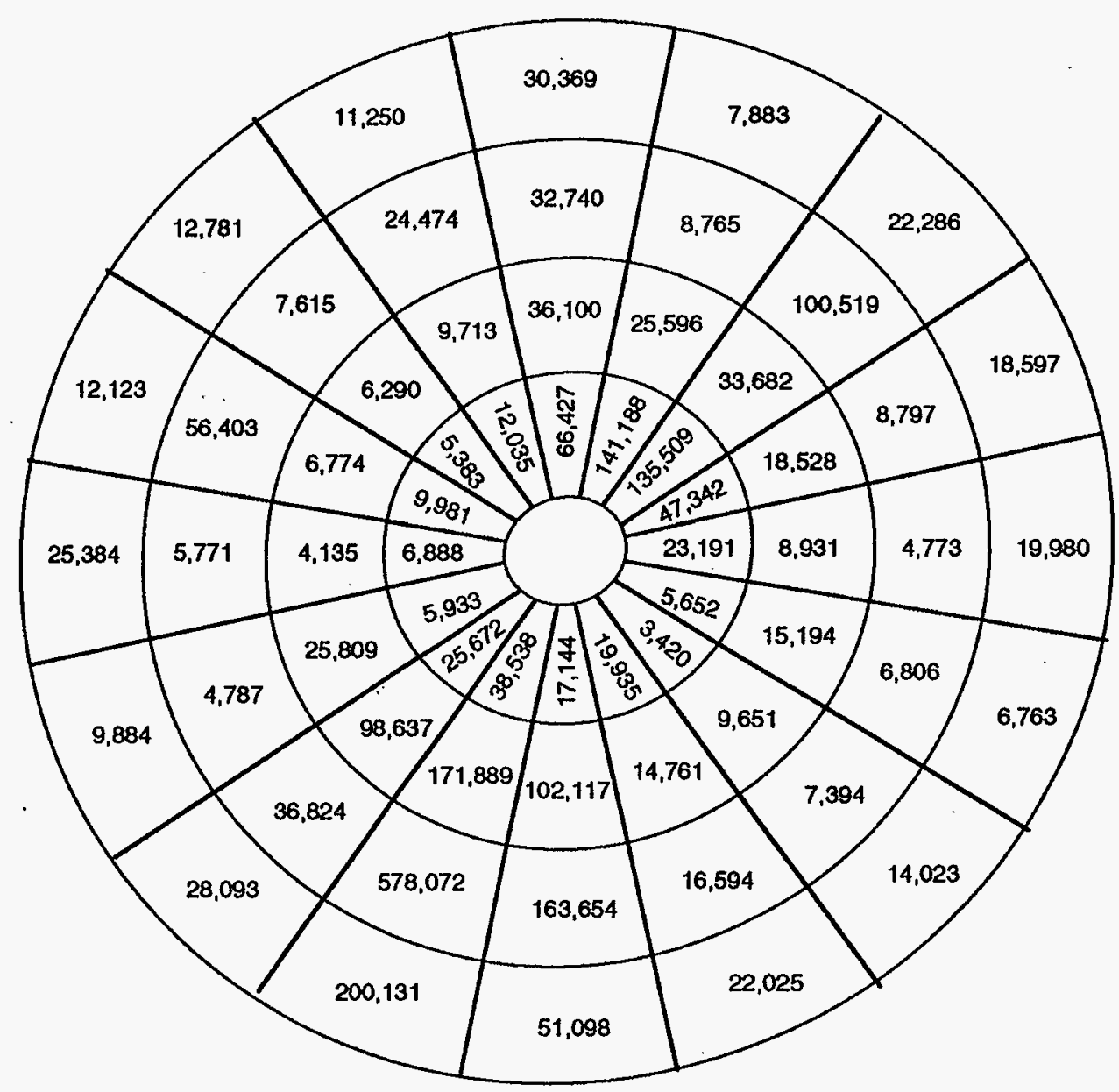

10 - 50 mlles

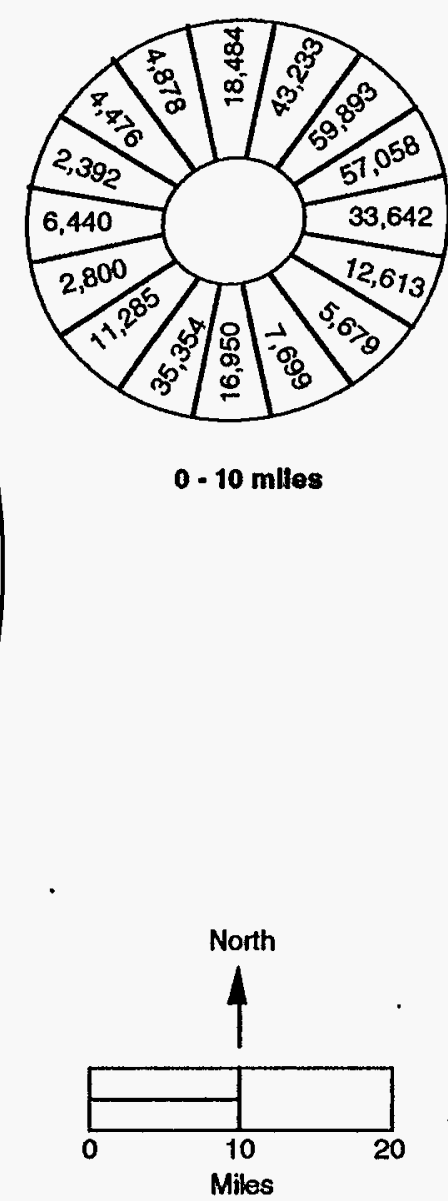




\section{Climate}

The climate is moderate. The average annual precipitation rate is on the order of $91 \mathrm{~cm}$ (36 in) per year. As shown in Figure 1-4, the total precipitation measured at Mound in 1993 was 85 cm (33 in).

For 1993, winds were predominantly out of the south southwest (Figure 1-5). The annual average wind speed measured at Mound for 1993 was 5.0 $\mathrm{m} / \mathrm{s}$ (11.2 $\mathrm{mi} / \mathrm{hr}$ ) (Table 1-2).

\section{Geology}

The geologic record preserved in the rocks underlying Mound indicates that the area has been relatively stable since the beginning of the Paleozoic era more than 500 million years ago. No evidence indicates subsurface structural folding, significant stratigraphic thinning, or subsurface faulting. Limestone strata, which are interbedded with protective shale layers at the site, show no evidence of solution activity. No evidence of solution cavities or cavern development has been observed in any borings or outcrops in the Miamisburg area.

Figure 1-4. Monthly Rainfall Measured at Mound in 1993

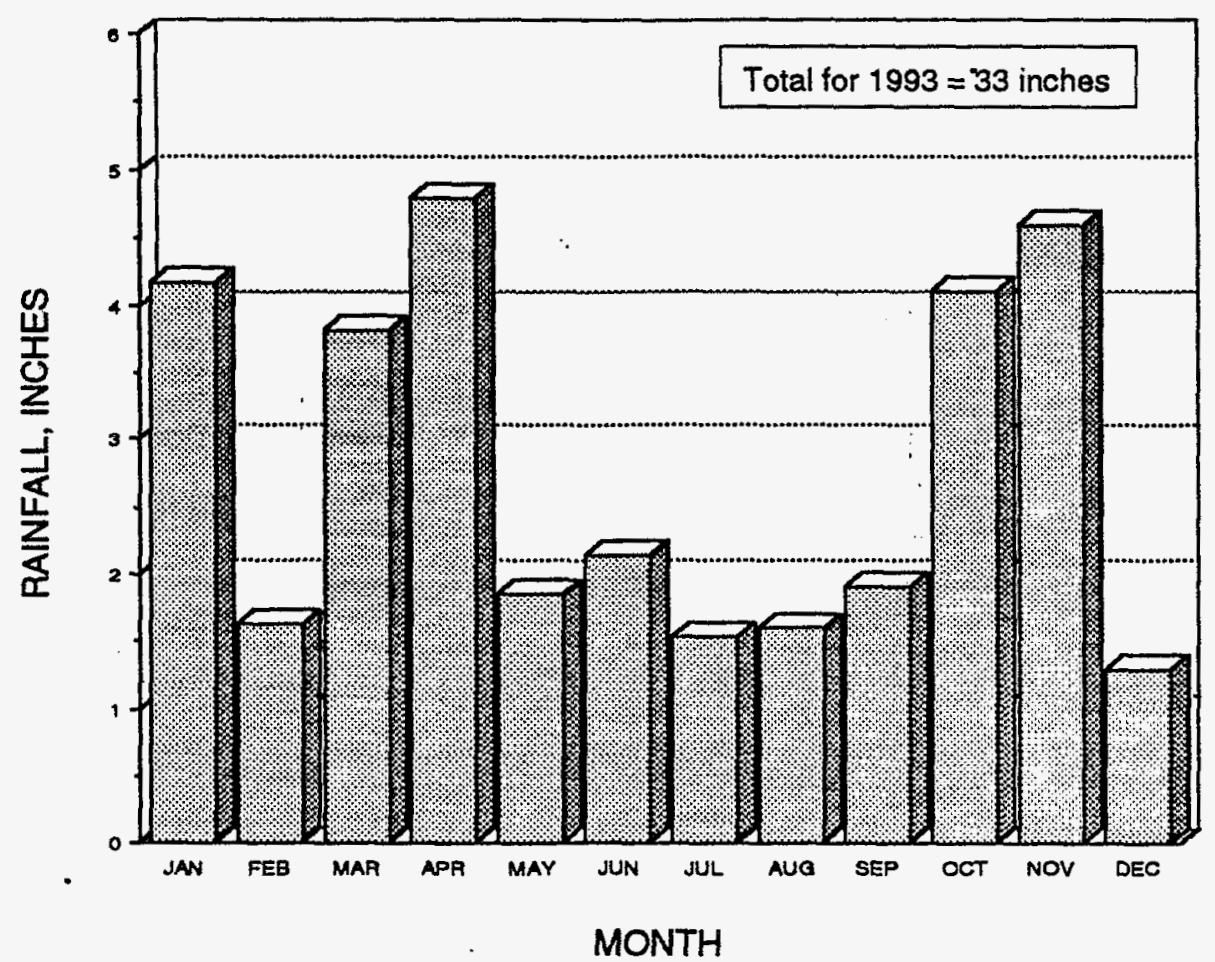


Figure 1-5. 1993 Wind Rose for the Mound Plant

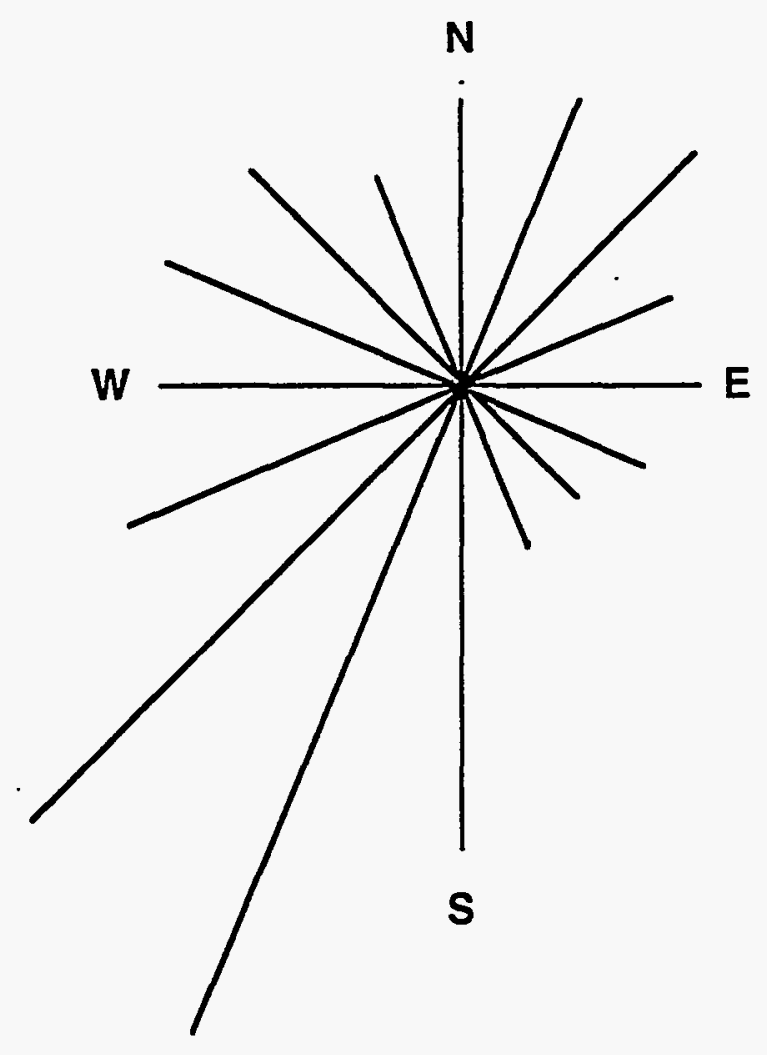

(Figure indicates frequency of winds blowing from a given compass sector. Data set is $99.2 \%$ complete.) 
Table 1-2. Percent Frequency of Wind Direction and Wind Speed from the Mound Plant 50-m Meteorological Tower for 1993

\begin{tabular}{lcc}
\hline Direction & Percent & $\begin{array}{c}\text { Average Speed } \\
(\mathrm{m} / \mathrm{s})\end{array}$ \\
\hline N & 5.5 & 4.6 \\
NNE & 5.9 & 4.6 \\
NE & 6.4 & 4.5 \\
ENE & 4.4 & 4.0 \\
E & 4.6 & 3.9 \\
ESE & 3.8 & 3.8 \\
SE & 3.0 & 4.0 \\
SSE & 3.3 & 4.3 \\
S & 8.9 & 5.4 \\
SSW & 13.5 & 5.8 \\
SW & 11.8 & 5.8 \\
WSW & 6.9 & 5.4 \\
W & 5.8 & 5.3 \\
WNW & 6.1 & 5.1 \\
NW & 5.8 & 4.5 \\
NNW & 4.3 & 4.1 \\
& & Average \\
\hline
\end{tabular}

Total relative frequency of calms distributed above is $0.2 \%$.

\section{Topography}

The site topography is shown in Figure 1-6. Mound site elevations vary from $216 \mathrm{~m}$ to $268 \mathrm{~m}$ $(700 \mathrm{ft}$ to $900 \mathrm{ft}$ ) above sea level; most of the Plant is above $244 \mathrm{~m}$ ( $800 \mathrm{ft}$ ). No building in which radioactive material is processed is located below an elevation of $241 \mathrm{~m}(790 \mathrm{ft})$. The typical nonflood stage of the Great Miami River is $208 \mathrm{~m}$ $(682 \mathrm{ft})$. The highest flood-water levels that can be reasonably postulated for the Great Miami River basin would result in flooding to $216 \mathrm{~m}$ $(710 \mathrm{ft})$, which is approximately the lowest elevation at the site. No buildings at Mound are located on a floodplain or in areas considered as wetlands.

\section{Mission and Operations}

Mound has served as an integrated research, development, and production facility in support of DOE weapon and nonweapon programs, especially in the areas of chemical explosives and nuclear technology. The principal mission of the Mound Plant has been to research, develop, and manufacture non-nuclear explosive components for nuclear weapons that are assembled at another DOE site. Other major operations at Mound have included:

- Manufacture of stable (nonradioactive) nuclides for medical, industrial, and general research.

- Development and manufacture of small chemical heat sources for the national defense program.

- Recovery and purification of tritium from scrap materials generated by Mound and other DOE sites.

- Development and fabrication of radioisotopic heat sources fueled with plutonium-238 to provide power sources for such projects as lunar experiments, satellites, and spacecraft.

- Surveillance of explosive and radioactive weapons components received from other DOE sites.

The DOE has proposed that the defense mission at Mound be discontinued. As a result, activities are underway to transfer Mound's defense-related programs to other sites within the weapons complex.

Therefore, in addition to completing the defense mission, primary Mound objectives for the future include the expansion of environmental restoration activities and the pursuit of new business opportunities for the site. 
Figure 1-6. Mound Site Topography

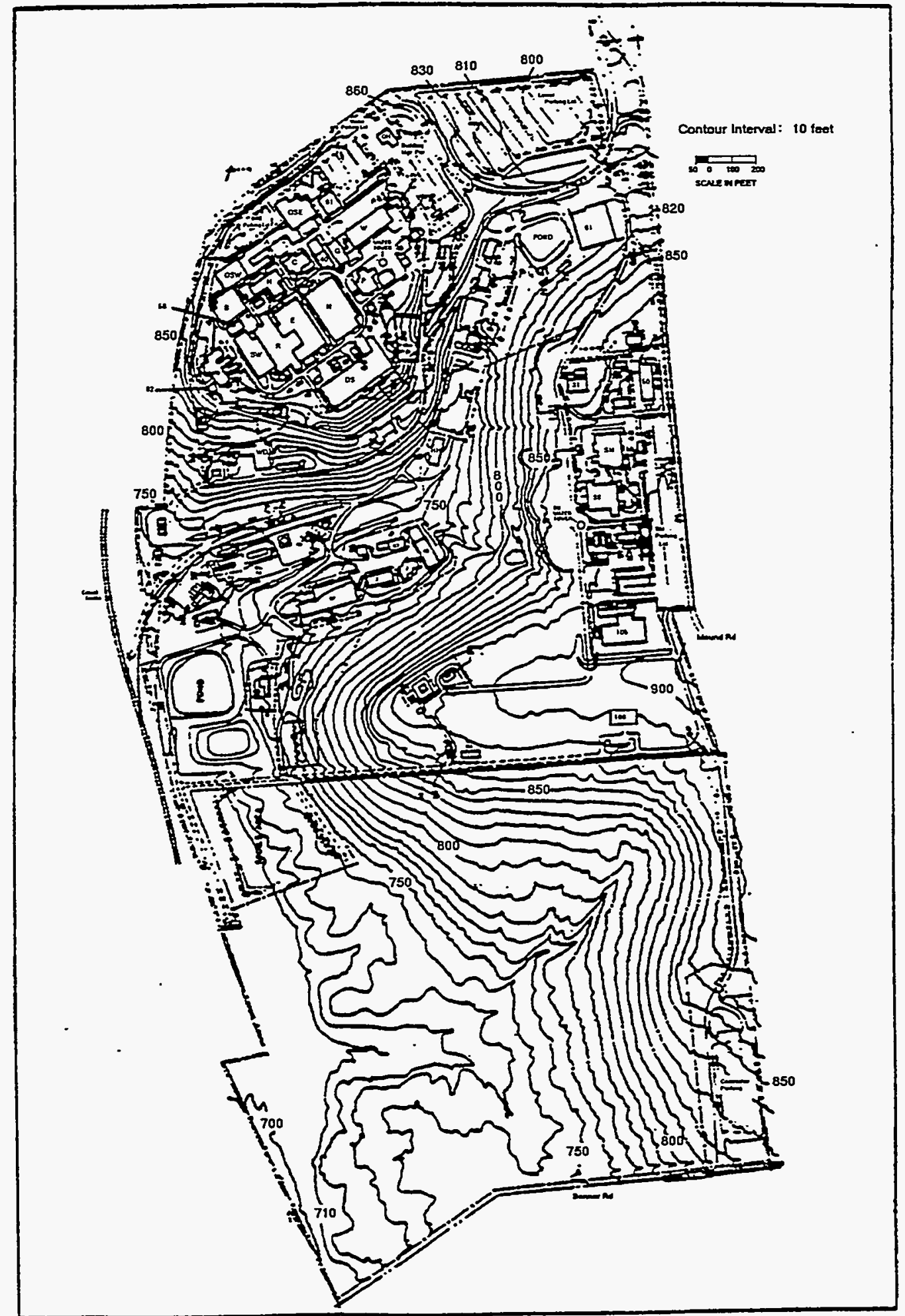




\subsection{Perspective On Radiation}

This section attempts to put into perspective the potential consequences of the radionuclidereleases described in subsequent sections of this report.

Most consequences to humans from radionuclides released to the environment are caused by interactions between radiations emitted by the nuclides and human tissue. These interactions involve the transfer of energy from the radiations to the tissue, a process that may damage the tissue. The radiations may come from radionuclides located outside the body (i.e., in or on environmental media and man-made objects) and from radionuclides deposited inside the body via inhalation, ingestion, or absorption through the skin. Exposure to radiation from nuclides located outside the body is called external exposure and will last only as long as the exposed person is near the external source. Exposure to radiation from radionuclides deposited inside the body is called internal exposure and will last as long as the radionuclides remain in the body.

A number of specialized units are used to characterize exposures to ionizing radiations. Because the damage associated with such exposures is due primarily to the deposition of radiant energy in tissue, these units are described in terms of the amount of energy absorbed by the tissue and the biological consequences of the absorbed energy. Some of these units are defined below.

- Absorbed dose indicates the amount of energy absorbed by a material (e.g., human tissue), divided by the mass of the material. The unit of absorbed dose is the gray (Gy) or the rad (100 rads $=1 \mathrm{~Gy})$.
- Dose equivalent indicates the biological effect of an absorbed dose on a particular organ or tissue. It equals the absorbed dose multiplied by factors that relate the absorbed dose to biological effects on that particular organ. The unit of dose equivalent is the sievert (Sv) or the rem $(100$ rem $=1 \mathrm{~Sv})$.

- Effective dose equivalent indicates an individual's fatal cancer risk from an exposure to ionizing radiation. It is calculated from the weighted sum of the dose equivalents from the irradiated organs. It is also expressed in rems or Sieverts.

- Committed effective dose equivalent indicates the total dose over the individual's projected remaining lifetime (assumed to be 50 years) that results from an intake during 1 year. The committed effective dose equivalent (CEDE) expresses the dose of internal radiation received when an individual has ingested or inhaled a radionuclide that will remain inside the body for months or years. It is also expressed in rems, mrems (1000 mrems $=1$ rem), or Sieverts.

- Collective committed effective dose equivalentindicates the sum of the committed effective dose equivalents to the individuals in a population. It gives an estimate of the expected health risk to the population from a dose of radiation. It can be used to calculate probable risks that might be too small to predict on the basis of a single individual. It is expressed in person-Sieverts or personrems. 


\section{Sources of Radiation}

Every day our bodies absorb ionizing radiation. Most of it comes from natural sources. Consumer products and medical procedures that use radiation are other common sources of ionizing radiation.

Natural Sources. Natural radiation comes from two sources-cosmic and terrestrial. Cosmic radiation results when energetic particles from outer space, traveling at nearly the speed of light, collide with nuclei in our atmosphere, creating showers of radioactive particles that fall to earth. The average annual dose equivalent received from cosmic radiation is $26 \mathrm{mrem}(0.26 \mathrm{mSv})$ for an individual living at sea level. Because cosmic radiation dissipates as it travels through the atmosphere, individuals living at lower altitudes receive less dose from this source than those living at higher altitudes.

Terrestrial radiation results when radionuclides that are a natural part of the earth's rocks and soils emit ionizing radiation. Because the concentrations of these radionuclides vary geographically, an individual's exposure depends on his location. The average annual dose equivalent from terrestrial radiation for an individual living in the U.S. is $28 \mathrm{mrem}(0.28$ $\mathrm{mSv}$ ).

Besides absorbing radiation from external radionuclides, we can aiso absorb radiation internally when we ingest radionuclides along with the food, milk, and water we ingest or along with the air we inhale. Once in our bodies, radionuclides follow the same metabolic paths as nonradioactive forms of the same elements. The length of time a particular radionuclide remains and emits radiation depends on whether the body eliminates it quickly or stores it for a long period, and on how long it takes for the radionuclide to decay into a nonradioactive form.
The principal source of internal exposure in the U.S. is believed to be radon. Inhalation of radon contributes about $200 \mathrm{mrem}(2.0 \mathrm{mSv})$ to the average annual dose equivalent from internal radiation. Other radionuclides present in the body contribute approximately 39 mrem $(0.39$ $\mathrm{mSv}$ ).

Consumer Products. Many familiar consumer products emit ionizing radiation. Some mustemit radiation to perform their functions, e.g., smoke detectors and airport $\mathrm{x}$-ray baggage inspection systems. Other products, e.g.; TV sets, emit radiation only incidentally to performing their functions. The average annual effective dose equivalent to an individual from consumer products ranges from 6 to $12 \mathrm{mrem}(0.06$ to 0.12 $\mathrm{mSv}$ ).

Medical Uses. Radiation is a tool for diagnosing and treating disease. The average annual dose equivalent for an individual in the U.S. from diagnostic radiation is $53 \mathrm{mrem}(0.53 \mathrm{mSv})$. Individuals undergoing radiation therapeutic procedures may receive much higher doses.

Summary. The contributions to an average individual's annual radiation dose are shown in Figure 1-7 (page 1-10). Mound's maximum contribution for 1993, $0.26 \mathrm{mrem}$, is too small to be included in the Figure. 


\section{Introduction}

Figure 1.7 Average Annual Radiation Dose in the U.S. (NCRP, 1987)

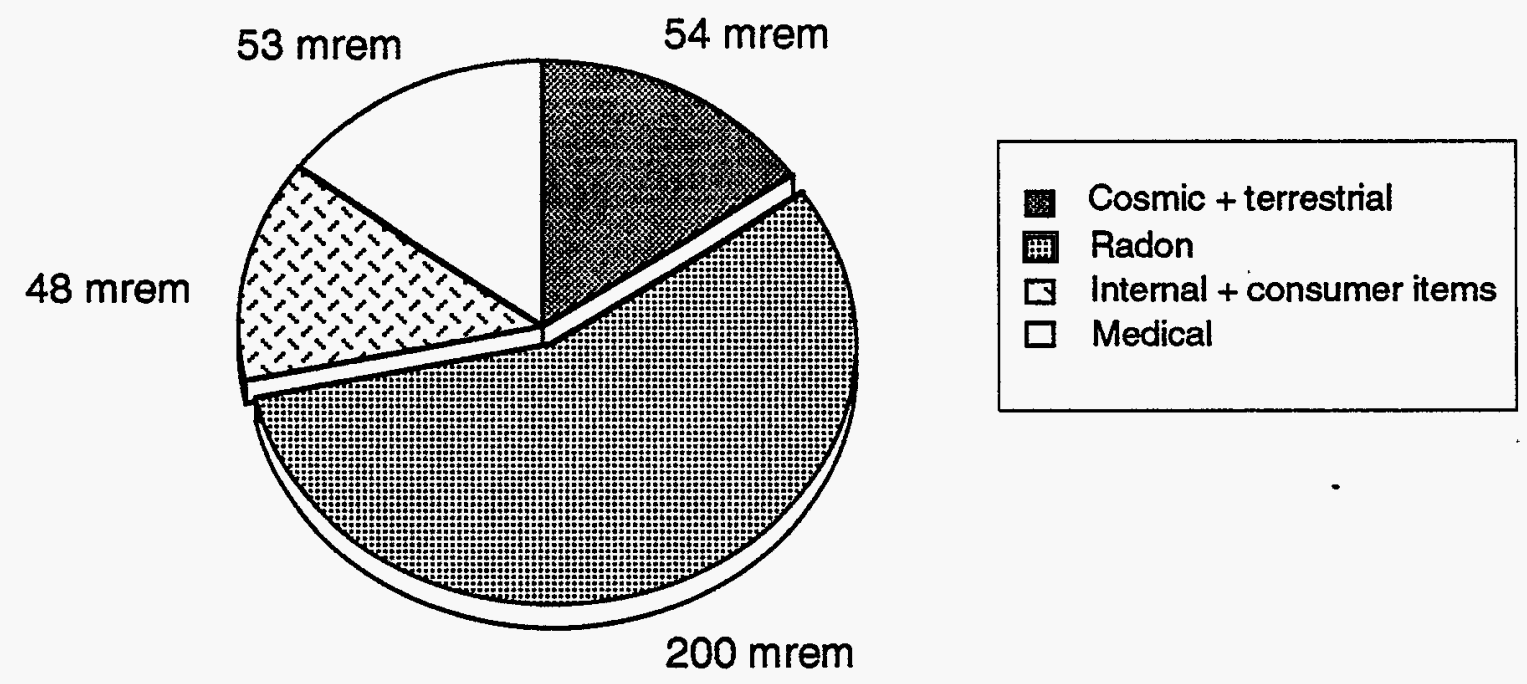




\subsection{COMPLIANCE SUMMARY}

The Mound Plant must operate in compliance with environmental requirements established by federal and state statutes and regulations. Additional requirements have been imposed by Executive Orders, U.S. Department of Energy (DOE) Orders, and a Federal Facilities Agreement (FFA). Mound's status with respect to each of those requirements is summarized below.

\subsection{Major Environmental Statutes, Regulation and Orders}

\section{Clean Air Act (CAA)}

Radiological emissions. Ten stacks at Mound discharge radioactive effluents to the atmospheric environment. These releases are subject to the National Emission Standards for Hazardous Air Pollutants (NESHAPs) for radionuclides. These "Radionuclide NESHAPs" regulations, 40 CFR 61, Subpart H, are components of the Clean Air Act (CAA) and are enforced by the U.S. Environmental Protection Agency (EPA).

The primary standard against which compliance with 40 CFR 61, Subpart $\mathrm{H}$ is measured is an annual effective dose equivalent (EDE). The regulations require that radionuclide emissions from a given site do not exceed those amounts that would cause a member of the public to receive an annual EDE of $10 \mathrm{mrem}(0.10 \mathrm{mSv})$. The regulation also states that each facility must determine this "maximum offsite dose" using an approved approach; the preferred approach is to use a computer code such as CAP-88.

Based on CAP-88 calculations performed for Mound's emissions in 1993, the maximum EDE received by a member of the public was 0.04 mrem. This value represents $0.4 \%$ of the dose limit and demonstrates that Mound releases for 1993 were well below allowable release levels.
NESHAPs for radionuclides also defines sampling and monitoring techniques which should be applied to stacks and vents that release radioactive materials. Mound is not in compliance with specific elements of those requirements. As a result, in November of 1991, Mound submitted to the U.S. EPA, Region 5, a two-year plan to bring Mound's effluent sampling and monitoring practices into full compliance. In response, EPA conducted a fact-finding visit on May 4, 1992. Based on that visit, EPA agreed to work with Mound on formalizing a schedule for achieving compliance.

A formal response to Mound's 1991 plan was received from the EPA on December 28, 1992. The response was in the form of a draft Federal Facilities Compliance Agreement (FFCA). The FFCA stipulates specific actions and deadlines the EPA feels are appropriate. DOE and EPA have negotiated final language for the FFCA; the Agreement became effective on July 7, 1994.

Nonradiological emissions. The Clean Air Act (CAA) of 1970, as amended in 1977, gave the EPA authority to regulate two groups of airborne pollutants: criteria pollutants and hazardous air pollutants. The CAA was again amended in 1990. The principal way in which those amendments affect operations at Mound relates to the phase-out of fully halogenated chlorofluorocarbons (CFCs). The amendments of 1990 called for a phase-out of CFCs such as freon because these chemicals are believed to be major contributors to stratospheric ozone depletion. 


\section{Compliance Summary}

To evaluate Mound's compliance with the CAA and its amendments, a preliminary survey of all emission points at Mound was conducted in 1991. Based on that survey, it was shown that the amounts of criteria pollutants, hazardous air pollutants, and ozone-depleting substances discharged by the Plant are well below applicable regulatory thresholds. However, future permitting requirements and the CFC phase-outmay generate new compliance issues in these areas. EG\&G Mound staff members monitor federal and state CAA developments and are prepared to respond to new requirements that may arise.

Mound is also subject to state and regional air pollution regulations. Compliance with State of Ohio regulations requires that all applicable Mound operations be permitted or otherwise registered. Mound has four air permits from the Ohio Environmental Protection Agency (OEPA). Two other sources are registered with the Regional Air Pollution Control Agency (RAPCA).

As a result of the 1991 survey described above, an additional 138 permit applications were submitted to RAPCA in the first quarter of 1992. Further review resulted in the submission of three additional applications. RAPCA is reviewing all of the applications and has indicated that a number of the applications may be consolidated and placed on registration status.

To ensure compliance with all state and local reporting requirements, comprehensive chemical air emission data were again collected in 1993. This information will be maintained in a data base that will be updated each calendaryear. In addition to providing information on release levels for materials regulated by the CAA, the data base will be used to meet the reporting requirements of other statutes such as the Emergency Planning and Community Right-to-Know Act.

Non-radioactive air release data for 1993 have been compiled (Table 5-1, page 5-1). All emissions were within required limits and no enforcement citations were received.

\section{Clean Water Act (CWA)}

The Federal Water Pollution Control Act (FWPCA) of 1972 was established to limit the types and rates of liquid effluents that may be discharged to the nation's waters. These limits are set for a specific site by the U.S. and/or state EPA using a National Pollutant Discharge Elimination System (NPDES) permit. An NPDES permit is also used to maintain compliance with more recent legislation, the Clean Water Act (CWA) of 1987.

Mound's current NPDES permit went into effect on October 1, 1992; it is valid through April 1, 1997. The permit defines discharge limits and monitoring frequencies for the Plant's liquid effluents. The permit also specifies biomonitoring activities Mound must perform on the receiving body of water, the Great Miami River.

Additionally, the new permit significantly reduced the amount of chlorine that may be present in specific Planteffluents. Among the Planteffluents subject to this limitation are discharges composed primarily of potable water. Potable water discharges tend to be high in chlorine content because chlorine is intentionally added to drinking water systems to protect them from bacteria and to comply with the chlorination standards of the Safe Drinking Water Act (SDWA). Therefore, to achieve compliance with Mound's NPDES permit without violating the SDWA, it will be necessary for the Plant to continue to chlorinate drinking water before use and to begin to dechlorinate it before discharge. For this reason, Mound's NPDES permit mandates a 36-month compliance schedule for the construction and operation of a dechlorination plant. Mound anticipates meeting this schedule. 
During calendaryear 1993, Mound collected 1574 samples for analysis of NPDES parameters. One exceedance did occur. On August 5, 1993, Mound recorded a chlorine concentration of $0.76 \mathrm{mg} / \mathrm{L}$ in the effluent discharged by the sewage treatment plant; the daily limit for Mound at that location is $0.5 \mathrm{mg} / \mathrm{L}$. This exceedance was reported to the OhioEPA within hours of occurrence. Corrective action to replace a faulty solenoid valve was promptly completed, the incident did not reoccur, and the OhoEPA did notissue a notice of violation or noncompliance.

\section{Safe Drinking Water Act (SDWA)}

The Safe Drinking Water Act (SDWA) of 1974 instructed the U.S. EPA to establish a program to protect drinking water sources. To meet this goal, the EPA has developed National Primary and Secondary Drinking Water Standards. These standards are applied to drinking water supplies "at the tap". Since Mound withdraws well water for use as drinking water, the Plant is subject to the requirements of the Act.

In Ohio, the SDWA is administered by the Ohio EPA. In accordance with Ohio EPA requirements, the Plant's drinking water system is routinely tested for various compounds. These analyses must be performed by a state-certified laboratory. For 1993, the analyses were performed by National Environmental Testing, Inc.; no violations of standards for bacteria, lead and copper, nitrate/ nitrite, or VOCs occurred.

Under the Ohio EPA's SDWA authority, Mound is also required to maintain a minimum chlorination level of $0.2 \mathrm{mg} / \mathrm{L}$ free chlorine (or $1.0 \mathrm{mg} / \mathrm{L}$ total chlorine) in the Plant's potable water system. This standard applies throughout the distribution system. Though Mound currently meets the standard, there have been isolated results indicating that the chlorine levels at specific locations were atypically low or high. Low chlorine levels would be a concern because they could foster bacteria growth. Continued bacterial testing of the Plant's drinking water systems, however, has demonstrated that a bacteria problem has not been encountered. High chlorine levels, on the other hand, do not present a safe drinking water concern, but rather are an NPDES compliance issue (seeClean Water Act discussion above).

A request to exempt the site from the chlorination standard is on file with the State of Ohio. The state has not acted on the exemption because the site does not meet current standards for backflow prevention and cross-connection control (Ohio Administrative Code 3745-95). On June 1, 1993 , construction began to eliminate all crossconnections between potable and other water systems such as the service and fire water systems. Upon completion in 1994, this project will bring Mound into compliance with OAC 3745-95.

\section{Resource Conservation and Recovery Act (RCRA)}

The Resource Conservation and Recovery Act (RCRA) of 1976, as amended by the Hazardous and Solid Waste Amendments (HSWA) of 1984, established a "cradle to grave" tracking system for hazardous wastes. The Acts led to the implementation of registration and/or permit requirements for all facilities that transport, generate, treat, store, and/or dispose of hazardous wastes. For the Mound Plant, the Ohio EPA administers this program.

Mound has "interim status" as a RCRA treatment and storage facility. "Interim status" provides for the continued use of these facilities while Mound awaits a formal permit from the OhioEPA. Mound has been seeking a permit for a number of years; the most recent permit application information was submitted on August 16, 1994. 


\section{Compliance Summary}

The operations at Mound subject to RCRA and HSWA are three hazardous waste storage units and three thermal treatment units. The storage units accommodate hazardous wastes, radioactive wastes that are also regulated by RCRA (i.e., mixed wastes), and energetic materials wastes. The thermal treatment units for which Mound is seeking a permit are associated with a glass melter, open burning of explosives, and explosives retorting.

Hazardous wastes. Hazardous wastes stored and/or treated onsite are managed pursuant to RCRA regulations on such issues as waste characterization, labeling, inspections for container integrity; facility performance criteria, and availability of protective and emergency response equipment. Those wastes not treated onsite are shipped offsite for approved treatment and/or disposal.

Mound has contracts in place for RCRA and nonRCRA waste transport and disposal. In 1993, the number of pounds of RCRA and non-RCRA wastes shipped offsite were 143,794 and 158,065 , respectively.

Mixed wastes. Wastes regulated by RCRA, but that are also radioactive, are referred to as mixed wastes or RCRA mixed wastes. These wastes present a unique compliance issue because treatment or disposal options have not been available. For this reason, Mound has been forced to store mixed wastes in quantities, and for time periods, that exceed RCRA limits. However, extensive efforts in 1993 resulted in the selection of a vendor for treatment of Mound's primary mixed waste stream. Before issuing a contract to the vendor, Mound personnel made a number of visits to the facility to ensure that all appropriate RCRA and Mound QA procedures are followed.
Suspect wastes. It is the policy of DOE that RCRA hazardous wastes originating in Radioactive Material Management Areas (RMMAs) be treated as "suspect" wastes, i.e., suspected of being radioactive. This precaution is necessary to ensure that hazardous waste management facilities do not receive radioactive wastes unless they are equipped and licensed to do so. As a result of this policy, in place since May of 1991, Mound is required to store wastes from an RMMA in the mixed waste storage facility. Mound has developed elaborate waste certification and characterization procedures which have allowed the Plant to dispose of stored suspect wastes. The procedures have also helped minimize the volume of suspect wastes now generated.

Nonhazardous solid wastes. Nonhazardous solid wastes generated at Mound are disposed of in a nearby sanitary landfill that is licensed and permitted. The volume of materials requiring landfill disposal was significantly reduced in 1993 by Mound's recycling programs for paper, aluminum cans, and scrap metal.

\section{Toxic Substances Control Act (TSCA)}

The goal of the Toxic Substances Control Act (TSCA) of 1976 is to protect human health and the environment from unreasonable risks associated with toxic chemical substances. The Act gave the U.S. EPA authority to govern the manufacture and use of chemicals deemed to present significant toxicity risks. Mound does not generate TSCA waste streams on a regular basis. However, efforts continue at Mound to remove TSCA wastes associated with past practices. The two primary areas comprising this category of Plant wastes are polychlorinated biphenyls(PCBs) and asbestos. 
PCBs. PCB-contaminated materials that are not suspected of being radioactive are stored onsite pending their shipment to an EPA-approved facility for disposal. "Suspect" PCB wastes those wastes originating in RMMAs - are retained onsite for waste characterization. Radioactively contaminated PCB wastes are also retained onsite. Because no disposal options are currently available for TSCA mixed wastes, they have been stored onsite in excess of the time limitations imposed by the Act.

The U.S. EPA is aware of Mound's mixed waste storage status and has not pursued compliance action. However, a notice of non-compliance for PCB recordkeeping was received from the U.S. EPA in 1993. The non-compliance involved a mandatory PCB equipment record. A corrective action response to the notice was promptly returned to the U.S. EPA.

Asbestos. The use of asbestos in pipes, panels, and as an additive to diallyl phthalate in parts production, has been discontinued at Mound. Residual asbestos is handled, packaged, and shipped offsite to an approved disposal facility in compliance with TSCA regulations.

Other asbestos removal projects continued in 1993 in connection with building renovation activities. All such projects are carefully monitored by the Industrial Hygiene Section to ensure compliance with TSCA and with Mound's Safety and Hygiene Manual.

\section{Comprehensive Environmental Response, Compensation, and Liability Act (CERCLA)/ Federal Facilities Agreement (FFA)}

The Comprehensive Environmental Response, - Compensation, and Liability Act (CERCLA) of 1980, also known as Superfund, is the federal government's primary environmental restoration legislation. Through CERCLA, the U.S. EPA identifies sites where contamination by hazardous substances may present a risk to human health and/or the environment. These sites are then placed on the National Priorities List (NPL) and subjected to a four-stage remediation process.

Mound was added to the NPL in November of 1989. A Federal Facilities Agreement (FFA) between the DOE and the EPA followed in October of 1990 . The FFA defined the responsibilities of each party for the completion of CERCLA-related activities.

The FFA became a tri-party agreement on July 15,1993 , when the Ohio EPA became a signatory. The addition of the Ohio EPA does not change the general purpose of the agreement, but rather provides a mechanism for the full participation of the Ohio EPA in the CERCLA process at Mound.

Preliminary CERCLA assessments of contamination at Mound identified approximately 125 locations of actual or suspected releases. These locations were grouped into "Operable Units" (OUs) based on waste type and/or geographical proximity. Originally, Mound established nine OUs. As CERCLA activities at Mound have progressed, changes to the number and composition of the OUs have been warranted. Three of the original OUs, Operable Units 3, 7, and 8 , have been eliminated from further consideration. This approach will save several million dollars and will expedite the cleanup process. A brief description of each operable unit can be found in Section 3.7 of this report.

In 1993, comprehensive evaluations of environmental media on and near the Plant continued. Additionally, EG\&GMound continues to expand its onsite soil, surface water, and well water sampling programs. Offsite characterization projects are also underway. Mound has designed an offsite testing program which involves six 


\section{Compliance Summary}

types of studies to be performed throughout a 20mile radius of the site. Those study areas are hydrogeology, seismic refraction, soil, wells and cisterns, surface water and sediment, and ecological assessments.

Also in 1993, the Agency for Toxic Substances and Disease Registry, ATSDR, continued its evaluation of Mound. It is a requirement of CERCLA that the ATSDR evaluate each site listed on the NPL. The Agency examines health data to seek out abnormal rates or types of illnesses. If any such problems are suspected, the Agency attempts to determine if a correlation exists between the illness and the site.

Initial ATSDR findings for the Mound Plant were published in October of 1993 as an ATSDR "Health Consultation". The consultation report indicated that plutonium-238 levels in the Mound environment are not a public health hazard. For other constituents of concern, insufficient data were available to draw public health conclusions. Therefore a key recommendation of the report was the pursuit of additional testing.

In addition to the activities described above, the Act established a list of CERCLA-regulated materials. Release of these materials to the environment is subject to certain reporting requirements. No releases of reportable quantities of CERCLA-regulated materials occurred at Mound in 1993.

\section{Emergency Planning and Community Right- to-Know Act (SARA Title II)}

The reauthorization of CERCLA came in 1986 in the form of the Superfund Amendments and Reauthorization Act (SARA). The Emergency Planning and Community Right-to-Know portion of that legislation is found in Title $\mathrm{II}$ of the Act.
SARA Title III, Section 312, requires that sites handling "extremely hazardous" and "hazardous" substances notify regional emergency planning agencies. In compliance with the Act, Mound annually reports hazardous chemical inventory data to the State Emergency Response Commission, the Miami Valley Regional Planning Commission, and the City of Miamisburg Fire Department. The inventory information is accompanied by maps showing the specific locations of the chemicals.

For 1993, Mound reported using and/or storing three "extremely hazardous" and eight "hazardous" chemicals. A listing of those chemicals is presented in Section 5.3 of this report.

\section{National Enviranmental Policy Act (NEPA)}

The National Environmental Policy Act (NEPA) of 1969 was established to ensure that consideration is given to the potential environmental impact of federal actions prior to the irretrievable commitment of resources. DOE has formalized its approach to NEPA by enacting regulations (10 CFR 1021). Mound has also formalized its approach by developing internal NEPA guidance documents.

Numerous checklists and other NEPA-related documents were prepared for Mound in 1993. One process, thermal treatment of RCRA mixed wastes, underwent a more formal NEPA review, and Environmental Assessment (EA). The EA for this unit has been submitted to DOE Headquarters and to the State of Ohio. 


\section{Endangered Species Act (ESA)}

Provisions of the Endangered Species Act (ESA) of 1973, as amended, prohibit federal departments such as the DOE from carrying out projects that would destroy or modify a habitat deemed critical to the survival of an endangered or threatened species.

EG\&GMound has performed a number of surveys for threatened or endangered species. Two potentialESA compliance issues have been noted. First, an endangered plant species, the Inland rush (Juncus interior), and an endangered bird species; the Dark-eyed junco (Junco hyemalis), have been observed onsite. It is notknown at this time if the species are truly indigenous to the area or were artificially transported here. More detailed studies are underway. Secondly, it has been determined that certain portions of the Plant site could serve as summer habitatareas for the Indiana Bat(Myotis sodalis). At this point, no Indiana bats have been observed onsite.

Neither the solitary sitings of the rush and the junco nor the potential habitat for the Indiana bat are expected to affectCERCLA operations onsite. However, through detailed ecological assessments, biologists will determine onsite plant and animal populations with specific emphasis on threatened and endangered species.

\section{Federal Facility Compliance Act (FFCA)}

The Federal Facility Compliance Act (FFCA) was signed into law on October 6, 1992. The FFCA requires that all DOE facilities prepare an inventory of mixed wastes and mixed waste treatment capabilities. In accordance with the Act, EG\&G Mound has prepared a Conceptual Site Treatment Plan. The Plan was submitted to the Ohio EPA in October of 1993. Upcoming milestones for the FFCA include preparation of the draft and final Site Treatment Plans by August 1994 and October 1995, respectively.

\section{Executive Order 11988, "Floodplain Management"}

The main plant site at Mound is not located in a floodplain. Recent investigations indicate that lower plant areas around the production wells may be in the 100-yr floodplain. This finding does not significantly affect operations at Mound.

\section{Executive Order 11990, "Protection of Wetlands"}

Ecological assessments conducted during CERCLA activities for the site will ensure compliance with this Order. Biologists will conduct surveys of sensitive environments including wetlands and floodplains.

\subsection{Other Key Environmental Compliance Issues}

\section{Tiger Team Action Plan}

EG\&G Mound continues to make improvements recommended by the 1989 DOE Tiger Tearn audit. These improvements are being implemented in accordance with a Corrective Action Plan developed for the Plant. As of December 31, 1993, 63 findings had been completed and 68 findings were scheduled for completion. Also as of that date, 52 closure packages for Tiger Team findings had been submitted. 


\section{Compliance Summary}

\section{Major External Environmental Audits in 1993}

U.S. EPA inspection. The U.S. EPA performed an inspection of Mound on September 1 and 2. The inspection focused on TSCA and FIFRA (Federal Insecticide, Fungicide, and Rodenticide Act) compliance issues. One item of noncompliance was noted with respect to FIFRA labelling requirements. Corrective action was promptly completed.

Ohio EPA inspection. The annual unannounced multi-disciplinary inspection of Mound by the Ohio EPA was conducted in June of 1993. Mound's nonradioactive air and water monitoring programs were evaluated. Additional areas covered by the inspection included: underground storage tanks, spill prevention measures, and management of PCBs.

As a result of the inspection, one item of noncompliance was noted. The citation involved an incomplete inspection record. A corrective action response was promptly submitted to the Ohio EPA.

Ohio EPA drinking water survey. On January 5, 1993, the Ohio EPA performed a sanitary survey of the Mound Plant potable water supply system. The purpose of the survey was to evaluate the capabilities of the collection, treatment, distribution, and storage facilities. The survey also reviewed the operational and managerial practices followed by EG\&G Mound to ensure that adequately safe drinking water is provided to all consumers. In the survey report it was noted that EG\&G Mound is conducting the required monitoring activities and that the water supplied by the Mound Plant complies with the state's safe drinking water laws. A key recommendation of the survey was to designate the three onsite production wells as groundwater sources.
Defense Nuclear Facilities Safety Board (DNFSB). The DNFSB reviewed Mound Plant operations during a November 29, 1993, through December 2, 1993, audit. Though environmental issues were not the primary focus of the visit, positive feedback regarding the environmental monitoring programs of EG\&G Mound was received.

DOE/NVO. An audit team from the Nevada Operations Office of DOE(DOE/NVO) evaluated Mound's Waste Certification Program for lowlevel radioactive wastes the week of August 9, 1993. EG\&G Mound Waste Mangement personnel submited final responses to the audit on December 6, 1993. Resolution of the issues raised by the audit and the follow-up actions is a key step toward the critical goal of securing approval to ship low-level radioactive wastes to the Nevada Test Site.

\section{Pending Lawsuit}

A class action lawsuit was filed against the Monsanto Research Corporation (MRC) and EG\&G Mound (EG\&G) on December 5, 1991. The lawsuit asserts that MRC and EG\&G, Mound's former and current contractor, respectively, "engaged in a continuous course of negligent ... and unlawful conduct resulting in ... repeated discharges of both radioactive and nonradioactive hazardous substances ... into the environmentsurrounding the facility." The lawsuit further asserts that these actions were "concealed from the plaintiffs."

EG\&GMound strongly believes this suit is without merit. As of the publication date of this report, a class had been conditionally certified, but the anticipated trial date of September 27, 1993, had been indefinitely postponed. All parties are currently awaiting the judge's ruling regarding a request to reconsider a specific motion or to certify the question to the Court of Appeals. 
Release data for Mound have been published each year in publicly distributed documents such as this report. The release data demonstrate the efforts taken by the Plant to operate within all applicable regulatory requirements and guidelines. Any individual who desires more information about operations at the Plant is encouraged to contact Mound's Public Relations Office.

\subsection{Summary of Permits}

Mound operates in compliance with four state air permits. Two additional sources of air emissions are on registration status with the State of Ohio. Liquid releases from the site are governed by an NPDES permit. In the area of waste management, the Plant has filed a site-wide RCRA permit application covering three waste storage facilities and three waste treatment units. The permits and their expiration dates are shown in Table 3-3. 
Compliance Summary 


\subsection{ENVIRONMENTAL PROGRAM INFORMATION}

The principal objective of the environmental programs in place at Mound is to ensure that any threat to human health or the environment is promptly detected and mitigated. It is also Mound policy that meeting this goal be viewed as a minimum standard of practice; better performance should always be pursued. The philosophy is evident in the extent and scope of Mound's effluent and environmental monitoring programs. It is also supported by Mound's commitment to successful programs in the areas of:

- ALARA (As Low As Reasonably Achievable),

- Regulatory compliance,

- Waste minimization and pollution prevention,

- Environmental training, and

- Environmental restoration.

\subsection{Effluent Monitoring}

\section{Air Emissions}

All applicable stacks at Mound are sampled continuously for tritium and/or particulate radionuclides. These samples are collected to demonstrate Plant compliance with the NESHAPs for radionuclides regulations. An outline of the stack sampling program is shown in Table 3-1.

\section{Liquid Releases}

Mound's liquid discharges are also sampled continuously at their discharge points. With liquid releases, however, the key concern involves nonradiological parameters. Extensive sampling and analysis is required of the Plant to demonstrate compliance with Mound's NPDES permit. Mound also samples a number of locations prior to discharge to ensure that any unexpected constituents are quickly detected. An outline of the liquideffluentsampling program is also shown in Table 3-1.

\subsection{Environmental Monitoring}

Mound's environmental monitoring program involves sample collection from ambient air, regional water sources, sediments, onsite and offsite groundwater, vegetation, fish, and produce. An outline of the program is shown in Table 3-2.

\section{Radionuclides of Concern}

The principal radionuclides of concern at Mound are tritium and plutonium-238; no other radionuclides contribute significantly to the dose estimates made each year for the Plant (see Appendix). Extremely small quantities of other radionuclides, however, are (or have been) used at Mound. In cases where there is a strong probability of detecting such radionuclides in the environment, they have been added to the appropriate sampling schedule. The primary example in this case is uranium. Because U-234 is a decay product of Pu-238, U-234 is a part of Mound's routine environmental monitoring program. Mound analyzes drinking water and river water samples to monitor the ingrowth of $U$ 234. No significant concentrations have been encountered. 
Table 3-1. Effluent Monitoring at Mound

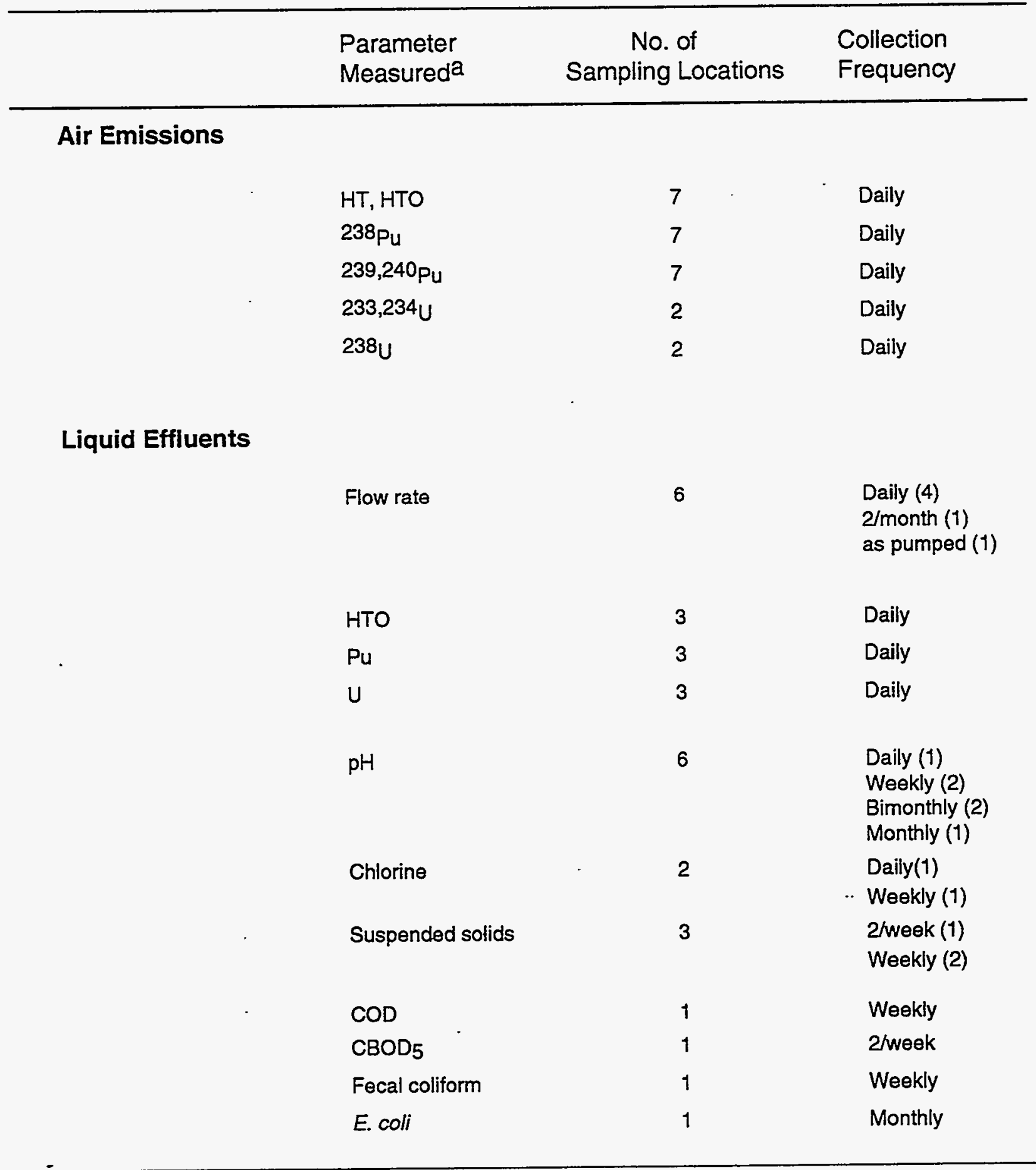

a HTO - Tritium oxide HT - Elemental tritium $\mathrm{Pu}$ - Plutonium
$U$ - Uranium CBOD5 - Five-day carbonaceous biochemical oxygen demand COD - Chemical oxygen demand 
Table 3-1 (continued)

\begin{tabular}{|c|c|c|c|}
\hline & $\begin{array}{l}\text { Parameter } \\
\text { Measureda }\end{array}$ & $\begin{array}{l}\text { No. of } \\
\text { ampling Locations }\end{array}$ & $\begin{array}{l}\text { Collection } \\
\text { Frequency }\end{array}$ \\
\hline & Ammonia & 1 & $2 /$ month \\
\hline & Oil and Grease & 2 & Monthly (1) \\
\hline & Free cyanide & 1 & Monthly \\
\hline & Total cyanide & 1 & $2 /$ month \\
\hline & Cadmium & 3 & $\begin{array}{l}\text { Weekiy (1) } \\
2 / \text { momth (1) } \\
\text { Monthly (1) }\end{array}$ \\
\hline & Chromium & 3 & $\begin{array}{l}\text { Monthly (2) } \\
2 / \text { month (1) }\end{array}$ \\
\hline & Copper & 3 & $\begin{array}{l}\text { Weakly (1) } \\
2 / \text { month (1) } \\
\text { Monthly (1) }\end{array}$ \\
\hline & Lead & 2 & Monthly \\
\hline & Mercury & 1 & 2/year \\
\hline . & Nickel & 3 & $\begin{array}{l}\text { Weekly (1) } \\
\text { 2/month (1) } \\
\text { Monthly (1) }\end{array}$ \\
\hline & Zinc & 3 & $\begin{array}{l}\text { Weekly (1) } \\
\text { 2/month (1) } \\
\text { Monthly (1) }\end{array}$ \\
\hline & Total toxic organics & 1 & Quarterly \\
\hline & Pentachlorophenol & 1 & Monthly \\
\hline & Bis(2-ethylhexyl) phthalate & 1 & Monthly \\
\hline . & $\begin{array}{l}\text { Toxicity testing } \\
\text { Ceriodaphnia dubia } \\
\text { acute } \\
\text { chronic } \\
\text { Pimephales promelas } \\
\text { acute } \\
\text { chronic }\end{array}$ & $\begin{array}{l}1 \\
1 \\
1 \\
1\end{array}$ & $\begin{array}{l}\text { Monthly } \\
\text { Quarterly }\end{array}$ \\
\hline $\begin{array}{l}\text { a HTO - Tritium oxide } \\
\text { HT - Elemental tritium } \\
\text { Pu - Plutonium }\end{array}$ & \multicolumn{3}{|c|}{$\begin{array}{l}\text { U - Uranium } \\
\text { CBOD } 5 \text { - Five-day carbonaceous biochemical oxygen demand } \\
\text { COD - Chemical oxygen demand }\end{array}$} \\
\hline
\end{tabular}


Table 3-2. Environmental Surveillance at Mound

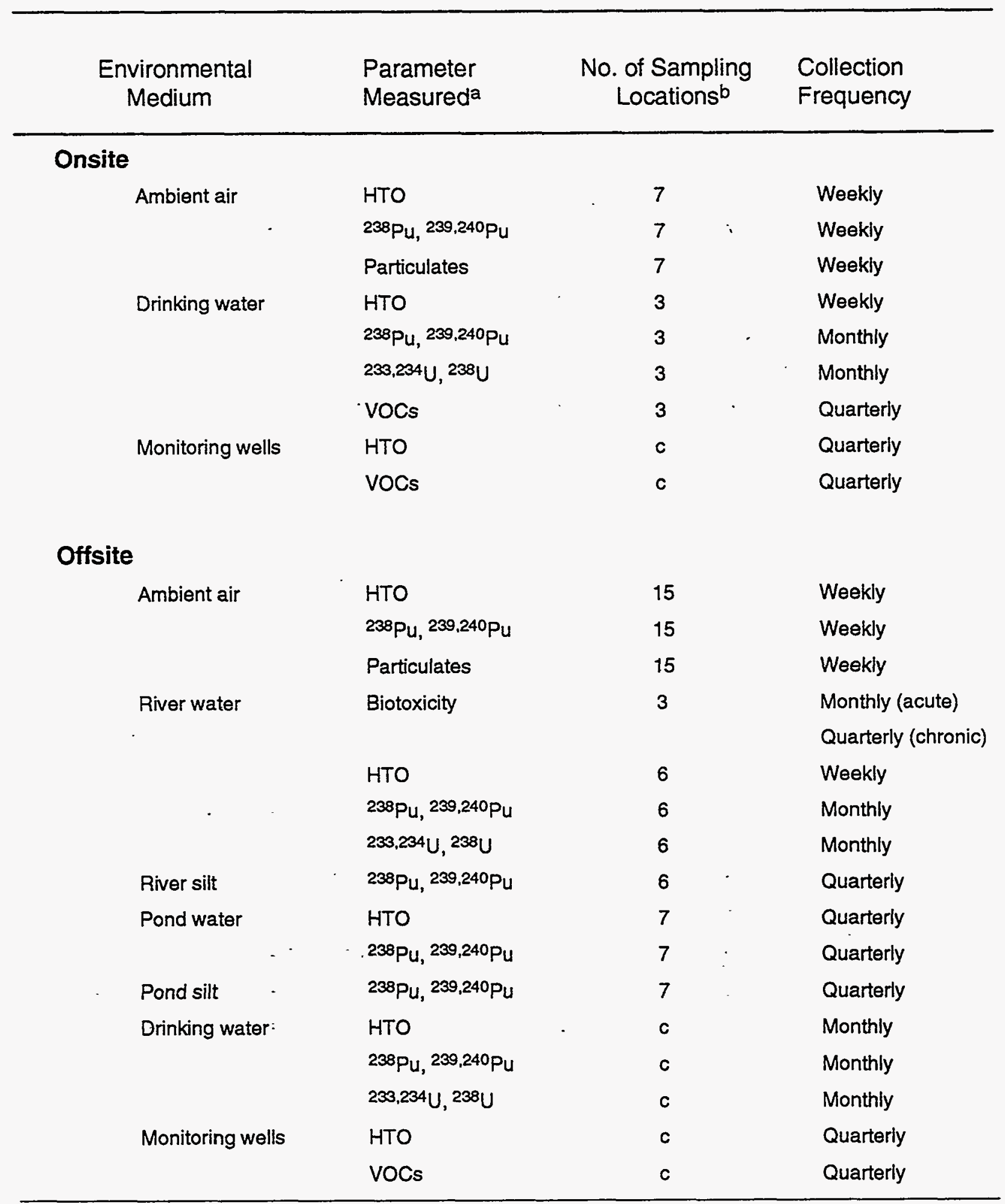

a HTO - Tritium oxide

b Inciudes background location when applicable.

c Number of sampling locations varies. Locations for 1993 are specified in Chapter 6. 
Table 3-2. (continued)

\begin{tabular}{|c|c|c|c|}
\hline $\begin{array}{l}\text { Environmental } \\
\text { Medium }\end{array}$ & $\begin{array}{l}\text { Parameter } \\
\text { Measureda }\end{array}$ & $\begin{array}{l}\text { No. of Sampling } \\
\text { Locations }^{b}\end{array}$ & $\begin{array}{l}\text { Collection } \\
\text { Frequency }\end{array}$ \\
\hline \multirow[t]{2}{*}{ Vegetation } & HTO & 7 & Quarterly \\
\hline & ${ }^{238} \mathrm{Pu},{ }^{239,240} \mathrm{Pu}$ & 7 & Quarterly \\
\hline \multirow[t]{2}{*}{ Produce } & HTO & 7 & Quarterly \\
\hline & ${ }^{238} \mathrm{Pu},{ }^{239}, 240 \mathrm{Pu}$ & 7 & Quarterly \\
\hline Fish & ${ }^{238} \mathrm{Pu}, 239,240 \mathrm{Pu}$ & 2 & Quarterly \\
\hline
\end{tabular}

\section{Rationale}

Environmental surveillance practices at Mound focus on those environmental media that are most likely to contain the radionuclide(s) of concern. For example, since $\mathrm{Pu}-238$ in river water tends to accumulate in sediments, Mound evaluates plutonium concentrations in sediment samples and in bottom-feeding fish such as carp.

The same rationale has been applied to the vegetation and produce sampling programs. Grass is sampled for $\mathrm{Pu}-238$ and tritium because grass can take up these radionuclides from both air and soil. Root crops such as potatoes are analyzed since the roots may come into contact with subsurface plutonium. Tomato samples, conversely, are of use due to their high water content; the high water content makes them excellent indicators of tritium uptake.

\section{Environmental Levels}

To evaluate Mound's impact on the environment, it is necessary to establish background or baseline levels of contaminants in a variety of media. Mound accomplishes this task by collecting samples at points where discharges from the Plant are not observable. These locations are usually in a direction opposite prevailing winds and at a distance too great to be impacted by the Plant. Concentrations measured at these reference locations are referred to as "environmental levels" in this report. 


\section{Environmental Program Information}

\subsection{Effluent Treatment and Waste Management}

\section{Effluent Treatment}

Air. High efficiency particulate air (HEPA) filters remove particulate radionuclides from process air emissions. Air effluents are filtered first at their point of origin (e.g., a glove box), and again just before reaching the release point (i.e., the stack or vent). The filtering system in place at each stack is composed of two banks of HEPA filters connected in series. Each filter bank has a nominal collection efficiency of $99.95 \%$ for 0.2 micron particles.

Tritium is not trapped by HEPA filters. A chemical process is used to recover tritium from waste gas streams.

Liquids. An onsite sanitary waste treatment plant manages all domestic sewage generated at Mound. An activated sludge process operated in the extended aeration mode provides the necessary treatment. The installation of a continuous backwash sand filter in 1986 essentially upgraded the plant to tertiary treatment. The influent and effluent at the sewage treatment plant are monitored for radioactivity to ensure that radionuclides are not inadvertently discharged to the environment. All wastewater, after appropriate treatment and monitoring, is discharged from the Plant to the Great Miami River. Digested sludge from the sewage treatment plant is managed as Low Specific Activity (LSA) waste.

\section{Waste Management}

Hazardous wastes. Mound has "interim status" as a RCRA treatment and disposal facility. "Interim status" provides for the continued use of
RCRA facilities while awaiting a formal permit. The operations at Mound subject to RCRA are three hazardous waste storage units and three hazardous waste treatment units. The storage units accommodate hazardous wastes, wastes that are both hazardous and radioactive, and energetic materials wastes. The thermal treatment units for which Mound seeks the permit are associated with a glass melter, open burning of explosives, and explosives retorting. Hazardous wastes not treated onsite are shipped offsite by a waste disposal firm for treatment and/or disposal using EPA-approved procedures.

Radioactive wastes. Low-level radioactive wastes generated at Mound are typically shipped to the Nevada Test Site (NTS) for disposal. No such shipments occurred in 1993. However, in August of 1994, the Waste Management Section of EG\&G Mound received approval to initiate additional shipments.

Nonhazardous, nonradioactive wastes. Solid wastes are disposed of according to a recycling and reclamation program whenever possible. White paper, scrap metal, and wood are sold for reclamation. General refuse is transported to a sanitary landfill approved by the county and the state.

\subsection{Environmental Permits}

Operations at Mound are routinely measured against the compliance requirements of four state air permits and one state NPDES permit. Additionally, Mound's hazardous waste program operates under interim status with the state's RCRA program. A current listing of the Plant's permits is shown in Table 3-3. 
Table 3-3. Environmental Permits Issued to Mound

\begin{tabular}{|c|c|c|c|}
\hline Operation & Permit No. & Valid Through & Issuing Agency \\
\hline Paint spray booth & $0857091196 \mathrm{KO01}$ & $11 / 26 / 95$ & Ohio EPA \\
\hline $\begin{array}{l}\text { Open-top } \\
\text { vapor degreaser }\end{array}$ & 0857091196L002 & $01 / 26 / 96$ & Ohio EPA \\
\hline $\begin{array}{l}\text { Open burning } \\
\text { (explosives disposal) }\end{array}$ & $\begin{array}{l}\text { N/A } \\
\text { letter permit }\end{array}$ & $11 / 01 / 94$ & Ohio EPA \\
\hline $\begin{array}{l}\text { Open burning } \\
\text { (firefighter training) }\end{array}$ & $\begin{array}{c}\text { N/A } \\
\text { letter permit }\end{array}$ & $\begin{array}{l}\text { Permanent } \\
\text { authorization }\end{array}$ & Ohio EPA \\
\hline $\begin{array}{l}\text { Wastewater discharge } \\
\text { (NPDES) }\end{array}$ & $11000005^{\star} \mathrm{DD}$ & $04 / 01 / 97^{\circ}$ & Ohio EPA \\
\hline $\begin{array}{l}\text { Hazardous waste } \\
\text { operations (RCRA) }\end{array}$ & N/A & Interim status ${ }^{a}$ & Ohio EPA \\
\hline
\end{tabular}

a The Mound Plant is operating under interim status. The revised Part $B$ application was submitted to the Ohio EPA on January 26, 1993.

\subsection{Environmental Training}

All Mound personnel received hazardous waste management training in 1993. Staff members with environment, safety, and health (ES\&H) responsibilities received much more extensive training. Key ES\&H training topics covered in 1993 included radioactive and hazardous materials handling; Department of Transportation regulations; updates on analytical techniques; Occupational Safety and Health regulations; and environmental law compliance.

\subsection{Waste Minimization and Pollution Prevention (WM/PP)}

Mound has established a Waste Minimization / Pollution Prevention Program to reduce the total volume and toxicity of Mound's hazardous, radioactive, and solid waste streams. These goals are accomplished at Mound by preventing waste generation, by recycling and reclamation, and by a variety of treatment techniques. The organizational structure of the Program is shown in Figure 3-1. 
Figure 3-1. Organizational Structure of Mound's Waste Minimization Program

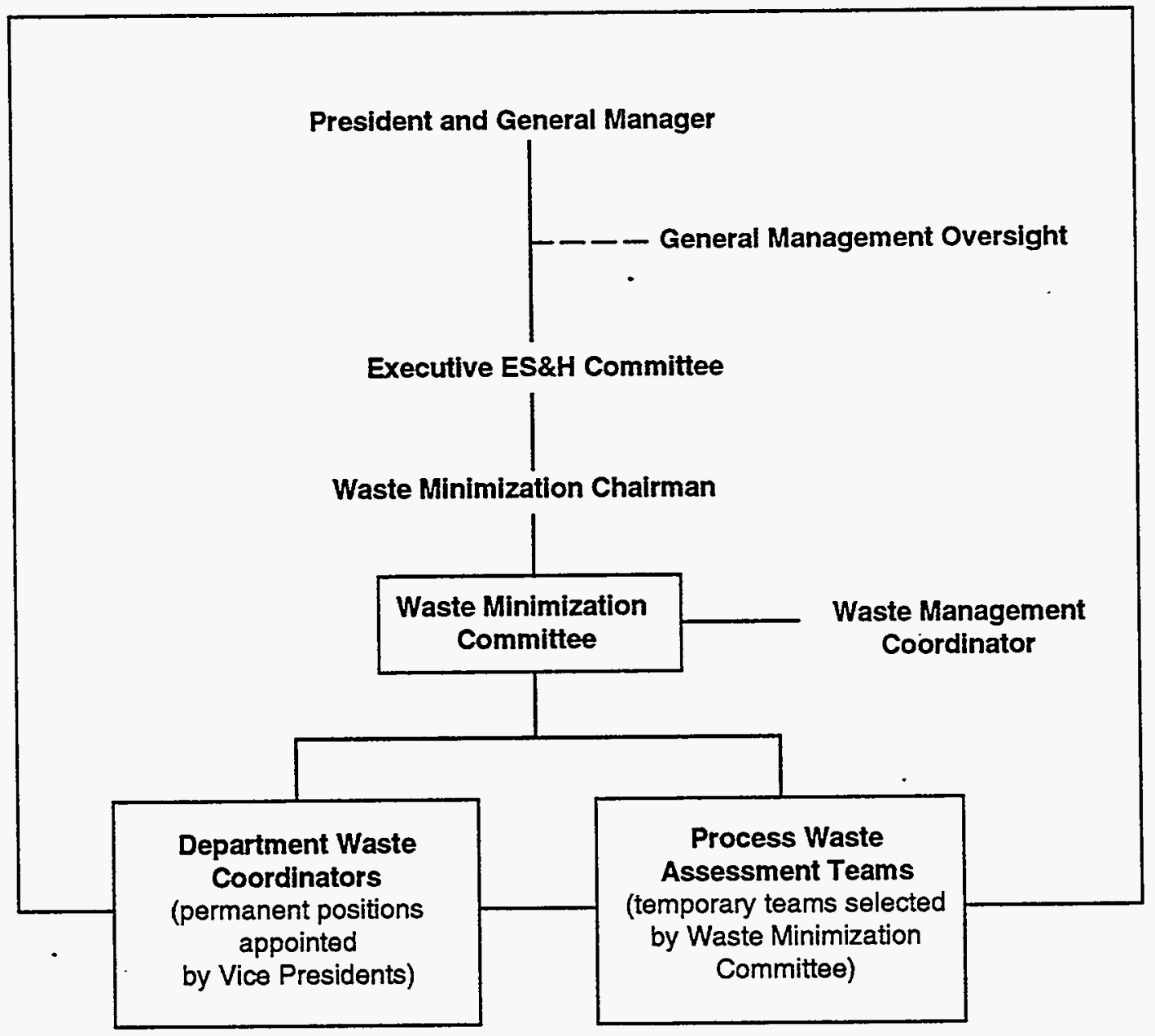


In 1993, six Process Waste Assessments(PWAs) were completed. Five involved energetic materials; the other assessed a tritium process. In all cases, the primary goal was to identify ways to reduce the volume of wastes generated.

Additionally in 1993, efforts continued to develop supercritical fluid and plasma cleaning technologies. (These techniques are potential alternatives to the use of chlorinated solvents and refrigerants.) It is hoped that these techniques will lead to the elimination of Mound's reliance on ozone-depleting substances like freon.

Through the efforts of the WM/PP Program, Mound significantly reduces the volumes of waste solvents and low specific activity wastes generated onsite. Long-term goals for the program are to continue to:

- reduce waste generation,

- expand recycling programs,

- encourage the use of non-ozonedepleting substances, and

- ensure employee awareness of these goals.

\subsection{Environmental Restoration (ER)}

Mound was added to the National Priorities List (NPL) in 1989. A Federal Facilities Agreement between DOE and the U.S. EPA followed in October of 1990. The FFA defines the responsibilities of each party for the completion of CERCLA-related activities. The bipartite FFA has been renegotiated to include the Ohio EPA as a signatory. The revised Agreement was signed by the three parties on July 15, 1993.

\section{Mound Plant Operable Units}

Preliminary CERCLA (Superfund) assessments of contamination at Mound identified approximately 125 locations of actual or suspected releases. These locations were grouped into nine "Operable Units", or OUs, based on waste type and/or geographical proximity. Three of these OUs, 7,8 , and 3 , are no longer necessary.

Operable Unit 7, Limited Action Sites. OU7 was eliminated in 1990 when testing found no evidence of contamination.

Operable Unit 8, Inactive Underground Storage Tanks. OU 8 included a number of inactive underground storage tanks (USTs). Some tanks were added to geographically appropriate OUs; the remaining USTs were placed in other regulated Mound programs. OU 8 was eliminated in January of 1993.

Operable Unit 3, Miscellaneous Sites. OU3 addressed 32 potential release sites throughout the Mound Plant for which little data were available. Testing for a variety of hazardous and radioactive constituents during 1991 and 1992 indicated that 23 of the 32 potential release sites did not need further CERCLA investigation. The remaining nine sites have been reassigned to OUs 2,5 , and 6 .

The elimination of OUs 3,7 , and 8 will expedite CERCLA activites at Mound and will provide considerable cost savings. The approximate boundaries of the remaining OUs are shown in Figure 3-2. A brief description of each operable unit and its status is presented in the paragraphs that follow.

Operable Unit 1, Area B. OU 1 represents sanitary landfill operational areas. The key concern for OU 1 is the potential migration of contaminated groundwater to the Great Miami River and the Buried Valley Aquifer. To evaluate the migration of contaminants, numerous monitoring wells and piezometers (devices used to measure water levels) have been installed. Soil contamination is also a concern. In 1993, remedial investigation field work was completed. 
Figure 3-2. Mound Plant Operable Unit Boundaries

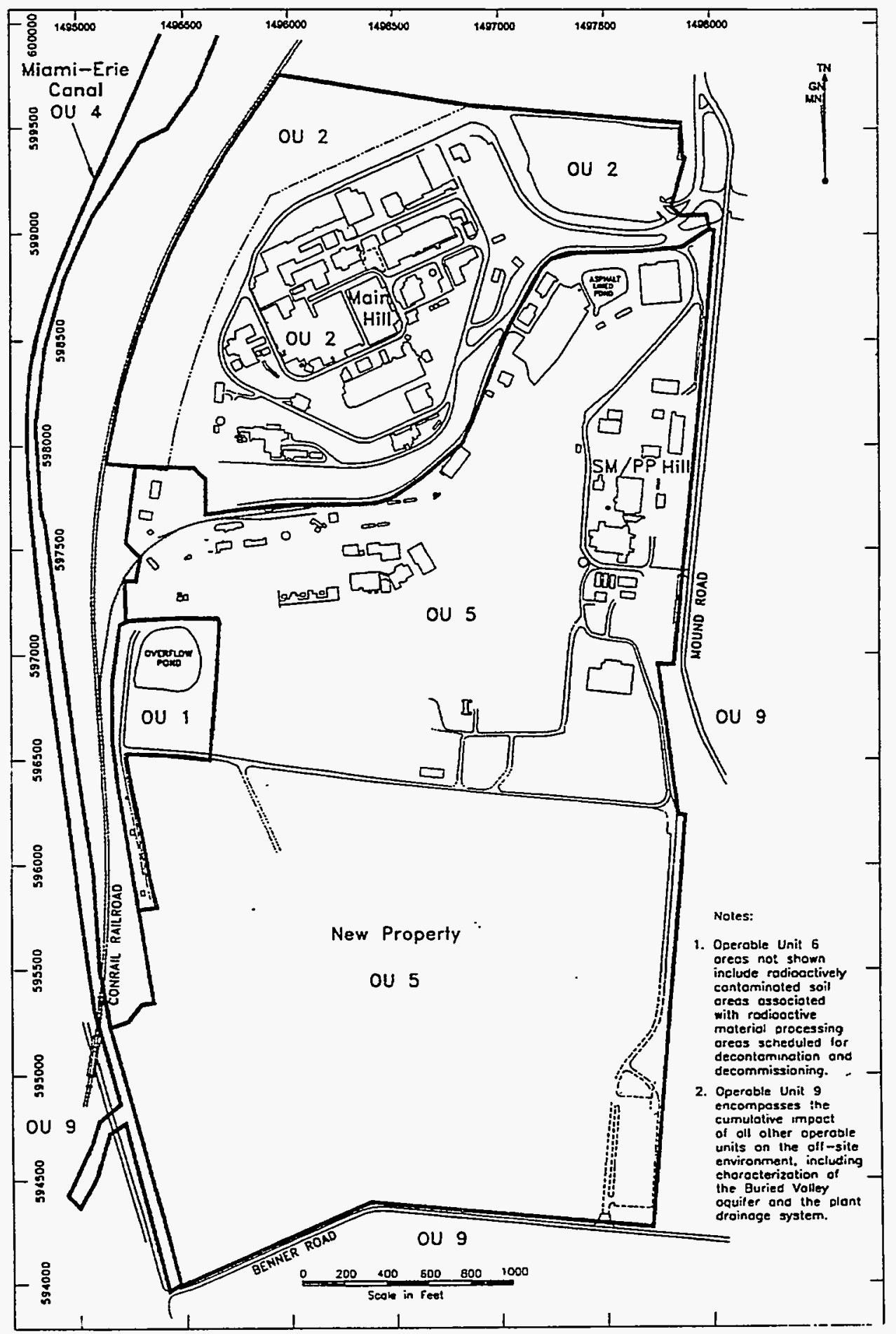


Operable Unit 2, Main Hill. OU 2 refers principally to the Main Hill seeps. Seeps occur when groundwater finds a path to the surface. A Work Plan for OU 2 is undergoing review. The Plan specifies the steps to be taken to investigate the migration of groundwater through cracks in the limestone cliffs comprising Mound's Main Hill.

Operable Unit 4, Miami-Erie Canal. OU 4 addresses an abandoned segment of the MiamiErie Canal just west of the Plant site. The Canal contains plutonium and tritium contamination as a result of a 1969 break of a waste pipe line. Treatment options for removal of plutonium from the Canal are being investigated. A report summarizing the results of special sampling activities in and around the Canal has been prepared.

Operable Unit 5, South Property. OU 5 includes soils with known or suspected radioactive contamination. The Remedial Investigation Work Plan is under review. A reconnaissance sampling report has been prepared.

Operable Unit 6, D\&D Sites. OU 6 addresses Decommissioning and Decontamination (D\&D) sites. These D\&D sites are areas of soil contamination that are undergoing removal or are scheduled for removal. Therefore, the primary role of ER for OU 6 is to verify cleanup after the soils are removed.

Operable Unit 9, Site-Wide and Offsite. OU 9 is the so-called Site-wide OU. This Unit is necessary to ensure that all data from individual units are compiled into a comprehensive assessment of offsite migration of contaminants in groundwater, surface water, soil, and air. Extensive testing is underway for OU 9. Key study areas include onsite and offsite groundwater, soil, sediment, and an evaluation of area plant and animal life.
Though the operable units described in this section are on or near the Plant site, regional sampling activities are also planned. Mound's CERCLA program intends to investigate possible environmental impacts within a 20 -mile radius of the site. Extensive groundwater, surface water, and surface and subsurface soil studies will be performed. Ecological assessments by qualified biologists are key components of the characterization efforts.

\section{ATSDR Participation}

In 1993, the Agency for Toxic Substances and Disease Registry, ATSDR, continued its evaluation of Mound. It is a requirement of CERCLA that the ATSDR evaluate each site listed on the NPL. The Agency examines health data to seek out abnormal rates ortypes of illnesses. If any such problems are suspected, the Agency attempts to determine if a correlation exists between the illness and the site.

Initial ATSDR findings for the Mound Plant were published in October of 1993 as an ATSDR "Health Consultation". The consultation report indicated that plutonium-238 levels in the Mound environment are not a public health hazard. For other constituents of concern, insufficient data were available to draw public health conclusions.

Key recommendation of the report included:

- additional tests of surface soils, surface water, and air; and a continuation of the existing

- ban on fishing in the South Pond of the Miamisburg Community Park.

ATSDR will continue to monitor CERCLArelated activities at Mound. ATSDR staff are frequent guest speakers at the CERCLA quarterly public meetings. They may also be contacted directly at their Atlanta, Georgia offices. 


\section{Environmental Program Information}

\subsection{Agreement-In-Principle}

The Agreement-In-Principle, or A-I-P, represents an added dimension to the environmental monitoring programs in place at DOE facilities in the State of Ohio. The A-I-P, under development for the past few years, was signed by the U.S. Department of Energy and the State of Ohio in 1993. The Agreement establishes the framework under which the State will provide oversight and monitoring activities at the Mound Plant, the Fernald Environmental Management Project, and the Portsmouth Gaseous Diffusion Plant.

Under the A-I-P, the Ohio Environmental Protection Agency will review DOE environmental monitoring programs and will perform independent monitoring and data collection. The Ohio EPA's primary mission will be to ensure that cleanup activities at these sites adequately protect human health and the environment. Additional oversight by the Ohio EPA will be applied to the emergency response and public information programs in place at each site.

The A-I-P provides $\$ 11$ million of support to Ohio EPA for an initial five-year period. This grant supplements the $\$ 21.5$ million previously committed by the DOE to support state regulatory programs. 


\subsection{RADIOLOGICAL ENVIRONMENTAL PROGRAM INFORMATION}

Operations at Mound result in the discharge of radioactive effluents to the air and the Great Miami River. Release limits on these discharges have been established by the Department of Energy and the U.S. EPA. Mound monitors release levels using a network of stack and water sample collection devices. In addition, Mound operates an extensive environmental surveillance program. Data generated from those programs are presented in this Chapter. As demonstrated by the data, radioactive releases from Mound in 1993 did not significantly impact human health or the environment.

\subsection{Radionuclide Releases from Mound}

\section{Data}

Table 4-1 lists the quantities of radionuclides released by Mound into the air and water during 1993. The unit used to report these quantities is the curie ( $\mathrm{Ci}$ ), a unit of radioactivity equal to 3.7 $x 10^{10}$ disintegrations per second. The quantities, or activities, shown in Table 4-1 were measured at the point of release. Information on the effluent monitors used to estimate release levels appears in Section 4.2 of this Chapter.

Table 4-1. Radiological Effluent Data for 1993

\begin{tabular}{lcc}
\hline Radionuclide & Released to & Activity, Ci \\
\hline Tritium & Air & $664^{\mathrm{a}}$ \\
& Water & 3.4 \\
Plutonium-238 & Air & $1.2 \times 10^{-5}$ \\
& Water & $2.5 \times 10^{-4}$ \\
Plutonium-239,240 & Air & $4.0 \times 10^{-8}$ \\
& Water & $8.9 \times 10^{-6}$ \\
Radon-222 & Air & $1.1 \times 10^{0}$ \\
Uranium-233,234 & Air & $6.3 \times 10^{-8}$ \\
& Water & $3.5 \times 10^{-4}$ \\
Uranium-238 & Air & $5.7 \times 10^{-8}$ \\
\hline
\end{tabular}

aTritium in air consists of: Tritium oxide, $522 \mathrm{Ci}$

Elemental tritium, $142 \mathrm{Ci}$ 


\section{Radiological Environmental Program Information}

\section{5-Year Trends in Radionuclide Releases}

It is Mound policy and philosophy that all releases of effluents from the Plant are ALARA, that is, As Low As Reasonably Achievable. To monitor Plant performance relative to ALARA goals, ALARA Investigation Levels (AILs) are established each year for principal radionuclides. AILs are set well below applicable regulatory standards to trigger internal investigations when exceeded.

Figures 4-1 through 4-8 illustrate 5-year trends in releases of tritium, plutonium, and uranium to the air and the Great Miami River. Mound's 1993 AILs have been included on the trend charts where applicable.

Tritium. Figure 4-1 shows releases of tritium to the atmosphere. The 1989 peak can be attributed to an accidental release. The 1993 value, $664 \mathrm{Ci}$, represents a 5-year low in release rates. Figure 42 shows tritium releases to the Great Miami River. The 3.4 Ci value for 1993 is typical of the release levels recorded over the 5-year period shown in the figure. In 1993, tritium releases to the atmosphere and the Great Miami River did not approach their respective Alls.

Plutonium-238. Figures 4-3 and 4-4 show plutonium-238 releases to the atmosphere and the Great Miami River, respectively. Atmospheric release levels were higher in 1993 when compared to 1992 values; conversely, 1993 liquid release levels were lower than 1992 values. As seen in the figures, both types of releases were small in comparison to their respective AILs.

Plutonium-239,240. Figures 4-5 and 4-6illustrate 5-year trends in Pu-239 and Pu-240 release rates. Releases of these plutonium isotopes continue to be in the $\mu \mathrm{Ci}$ and sub- $\mu \mathrm{Ci}$ ranges.

Figure 4-1. Tritium Releases from Mound to the Atmosphere, $1989-1993$

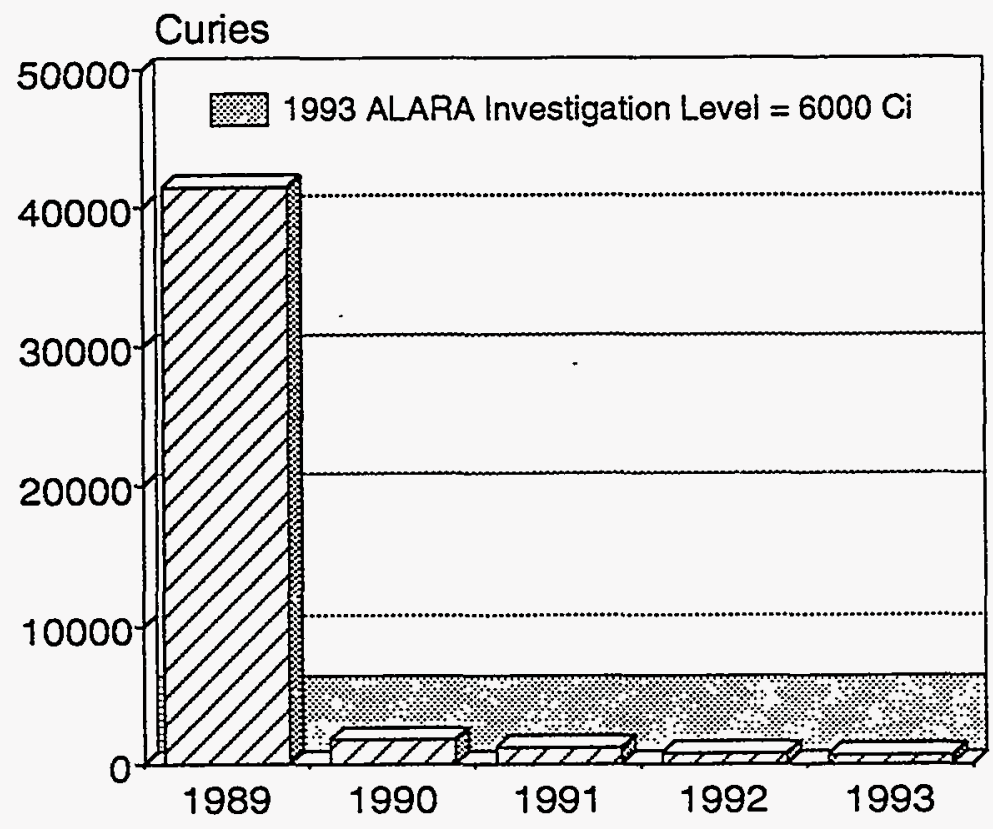


Figure 4-2. Tritium Releases from Mound to the Great Miami River, 1989 - 1993

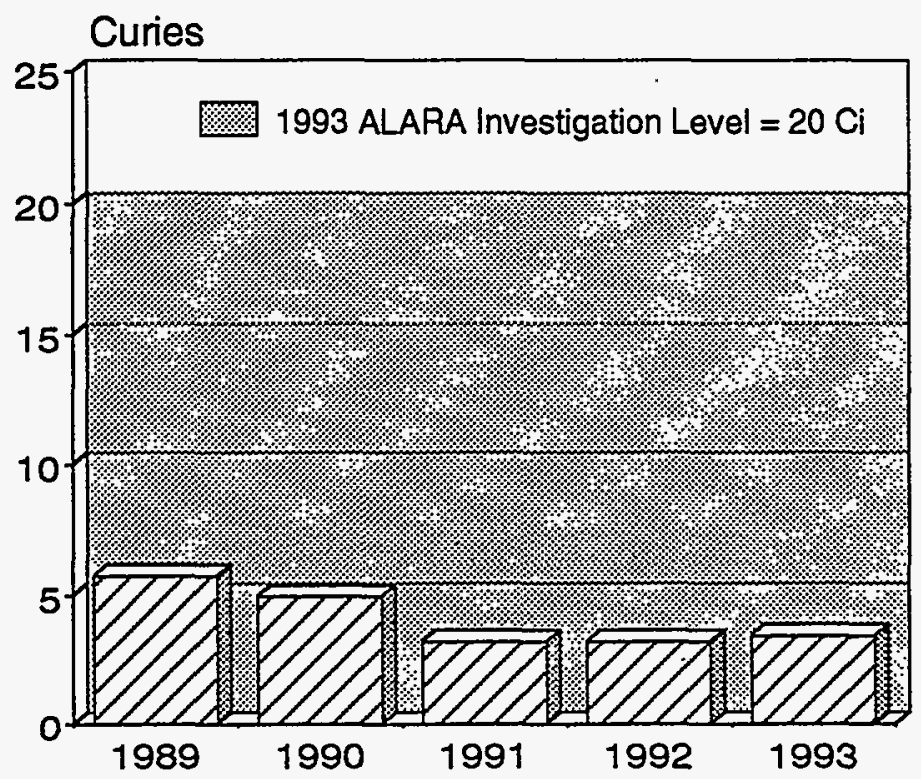

Figure 4-3. Plutonium-238 Releases from Mound to the Atmosphere, 1989 - 1993

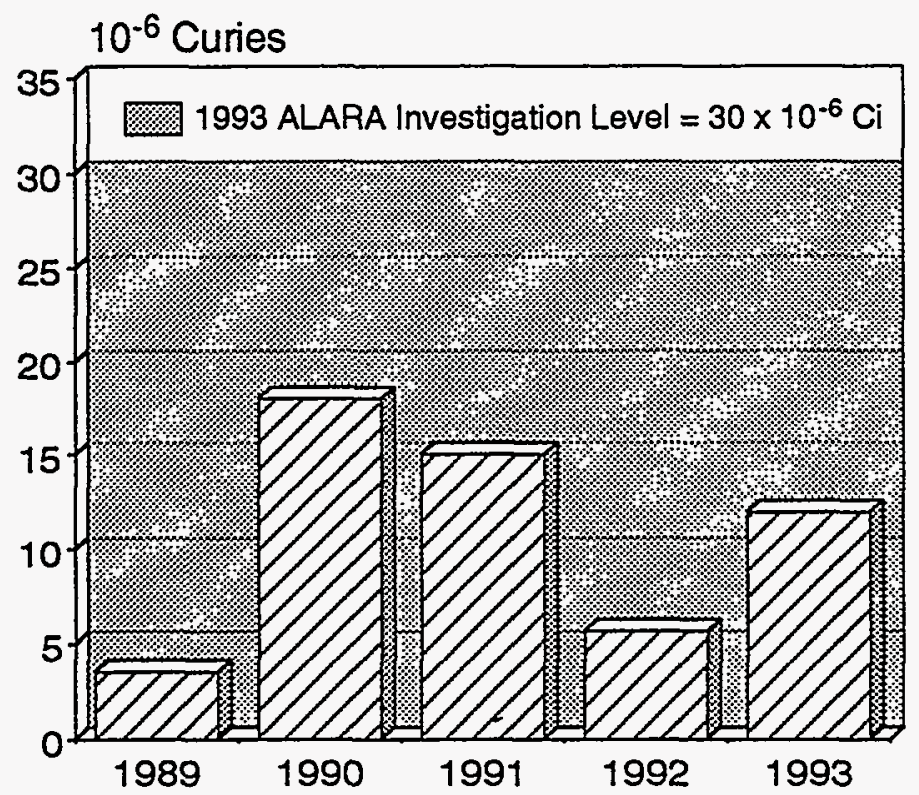


Figure 4-4. Plutonium-238 Releases from Mound to the Great Miami River, 1989 - 1993

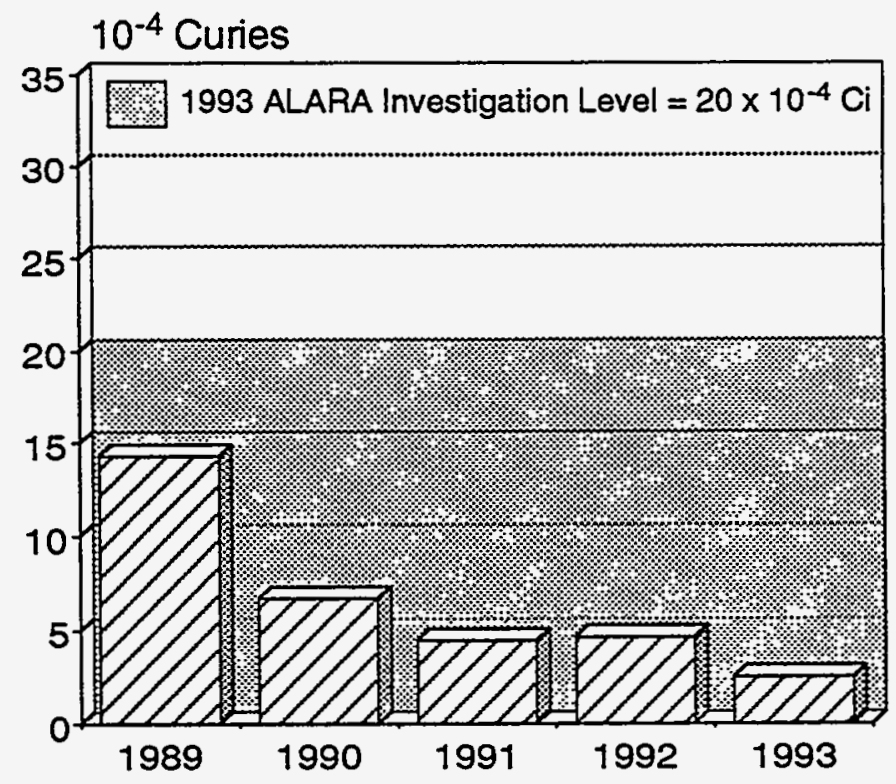

Figure 4-5. Plutonium-239,240 Releases from Mound to the Atmosphere, 1989 - 1993

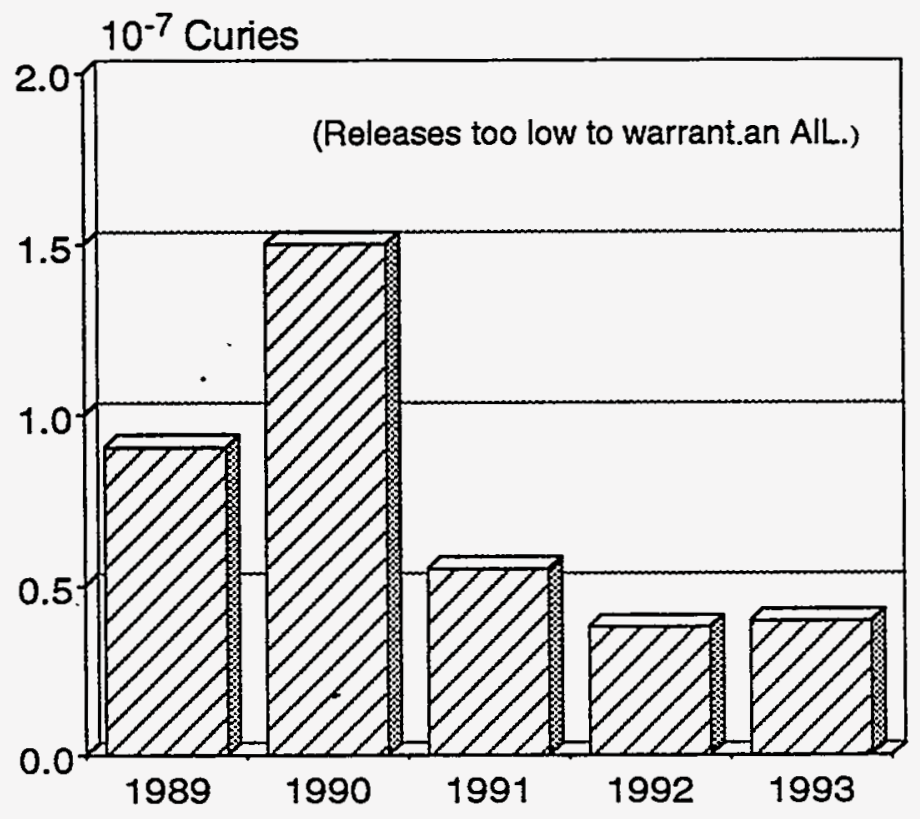


Figure 4-6. Plutonium-239,240 Releases from Mound to the Great Miami River, 1989 1993

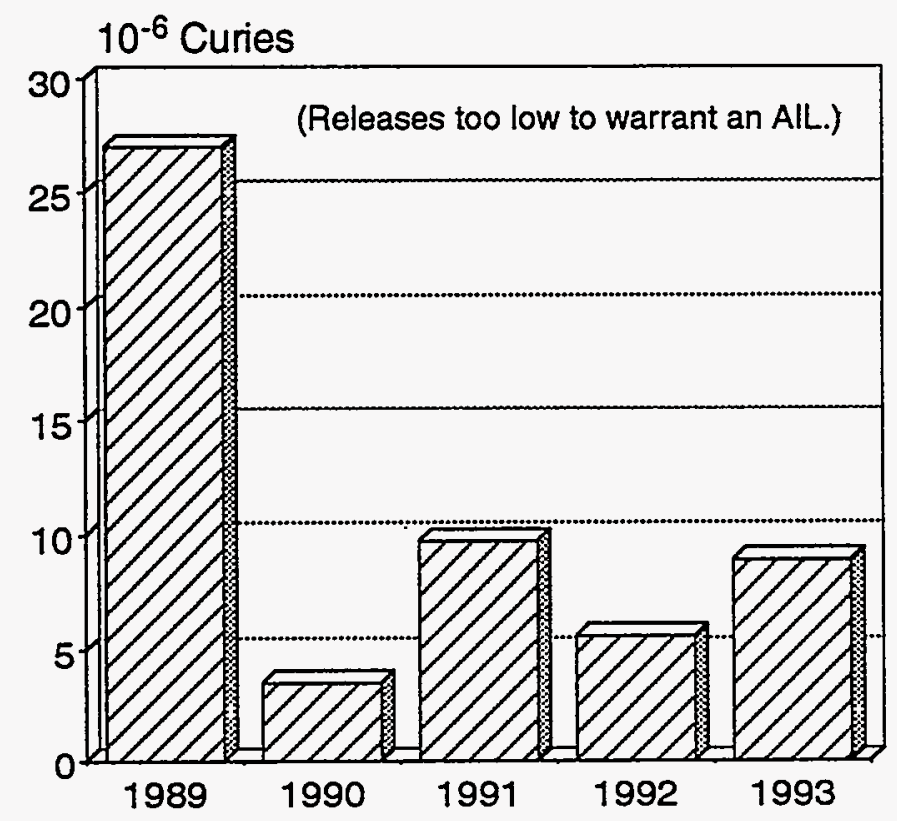

Uranium. Figures 4-7 and 4-8 depict 5-year trends in uranium-233,234 and uranium-238 release rates. Atmospheric releases of uranium are also on the sub- $\mu$ Ciscale. Releases of uranium233,234 to the Great Miami River are comparable to Pu-238 release levels for the River. As seen in Figure 4-8, uranium release rates have remained stable over the 5-year period and the $1993 \mathrm{AIL}$ was not exceeded.

\subsection{Effluent Monitoring Program}

\section{Air}

Stacks through which radioactive materials are released are sampled continuously. Those areas in which a potential for unplanned releases exists are also monitored continuously.
Tritium. In operational areas where a release potential exists, room air and exhaust stacks are continuously monitored for tritium using strategically placed ionization chambers. These monitoring systems incorporate alarms and have been placed to help to locate the source if a release should occur. In most situations, an effluent removal and containment system can be relied upon to prevent or reduce the release of tritium to the atmosphere.

Plutonium and Uranium. In operational areas where a release potential exists, ventilation air passes through a minimum of two HEPA filters before being discharged to the atmosphere. Fixed continuous air samplers and continuous air monitors with alarm systems are used throughout the operational areas to detect airborne plutonium and/or uranium. These monitoring systems have been designed to ensure that prompt corrective action can be taken to reduce the number and magnitude of releases to the atmosphere. 
Figure 4-7. Uranium Releases from Mound to the Atmosphere, 1989 - 1993

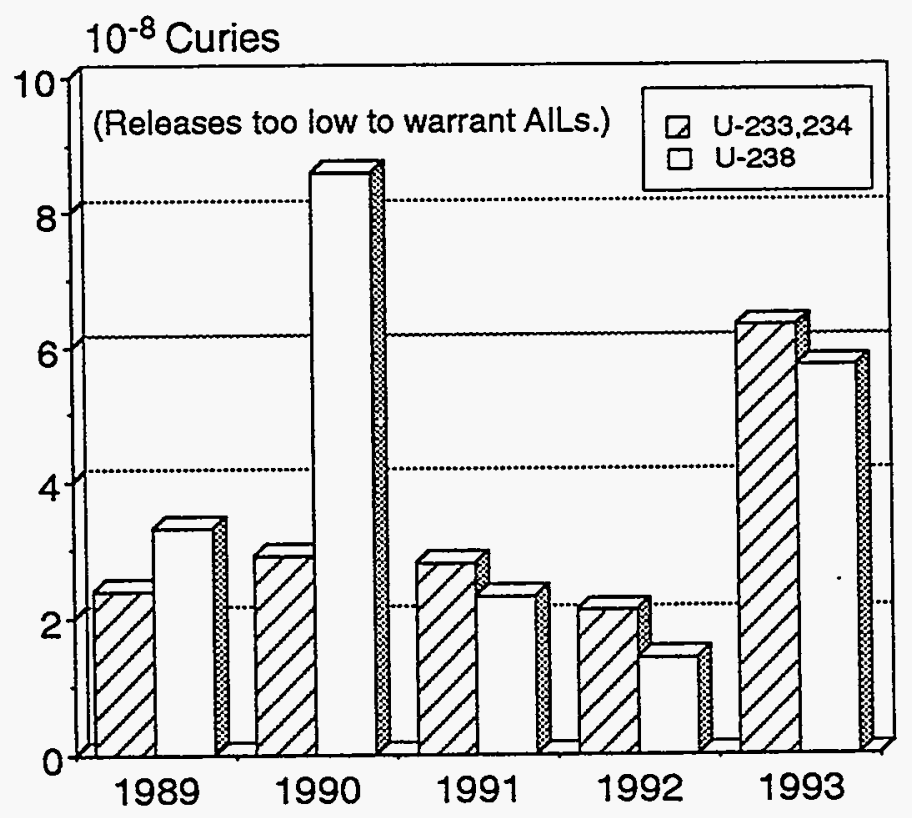

Figure 4-8. Uranium-233,234 Releases from Mound to the Great Miami River, 1989- 1993

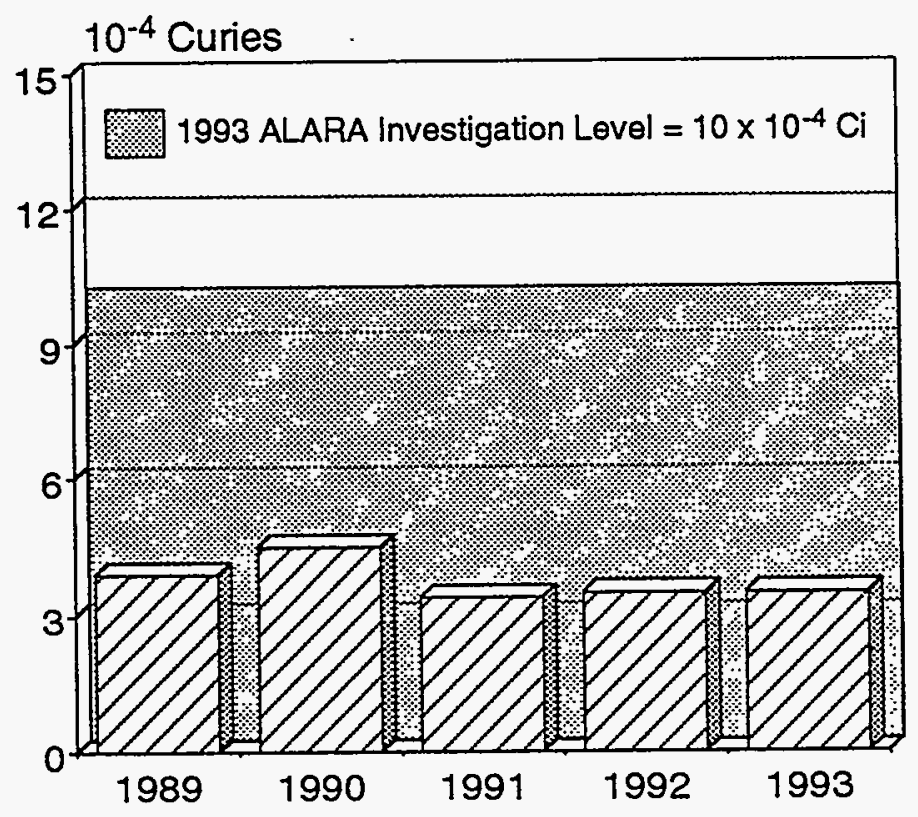




\section{Chapter 4}

Radon. Radon-222 from natural sources, and from past operations involving radium-226, is continually released to the atmosphere via a small roof vent. Though emission levels are negligible in comparison with natural radon emanation rates, a radon- 222 release rate has been included in the 1993 effluent data (Table 4-1) in the interest of completeness.

\section{Water}

Flow-proportional samples are collected from NPDES outfalls 5002, 5601, and 5602 (Figure 49). Samples are collected four times during Mound's four-day work week. Three 24-hour samples are collected on Tuesdays, Wednesdays, and Thursdays. One 96-hour sample is collected on Mondays. Samples are analyzed four times a week for tritium. Plutonium-238, plutonium239,240 , and uranium-233,234 samples are composited and analyzed on a weekly basis.

Release data for 1993 were shown in Table 4-1. Trend data for the 5-year period 1989-1993 appeared in Figures 4-1 through 4-8.

\subsection{Environmental Surveillance}

In the sections that follow, tables of environmental monitoring results are presented. The tables show the:

- number of samples analyzed during the year,

- minimum concentration measured,

- maximum concentration measured,

- average value with error limits, and, when appropriate, a

- comparison to a DOE or EPA standard.

\section{Environmental Concentrations}

In a number of the tables, results are presented as "incremental concentrations". This designation indicates that an average background concentration, or "environmental" concentration, has been subtracted from those values. Therefore, incremental concentrations represent estimates of Mound's contribution to the radionuclide content of an environmental sample.

Environmental or reference locations for Mound were positioned at sites where virtually no impact from Mound could be measured. The sites are in the least prevalent wind direction and/or are at substantial distances relative to Mound. Environmental levels for radionuclides in different environment media are shown in Table 4-2.

With decreasing releases rates of radioactivity, it has become increasingly difficult to observe Mound's contribution to radionuclide concentrations in the environment. For this reason, many of the tables in this Chapter report data as "below environmental levels". In those cases, it was not possible to observe an incremental concentration. In other words, the radionuclide concentration in that sample was equal to or less than the background sample.

\section{Lower Detection Limit}

All concentrations of radionuclides are determined by subtracting the instrument background and reagent blanks from the sample count. The lower detection limit (LDL) is shown for each set of data in this Chapter. The LDL is that value at which the presence of a contaminant, above that inherent in the detection method (including the reagent blank), can be inferred at the $95 \%$ confidence level. An LDL is calculated from the instrument background, the reagent blanks, and their respective estimated standard deviations.

\subsection{Air Sampling Program}

Two types of air samples are collected at each sampling location. A particulate air sample is analyzed for plutonium-238 and plutonium239,240 . A second air sample, collected in a bubbler apparatus, is analyzed for tritium oxide. Mound operates a network of 22 stations: seven onsite and 15 offsite. The locations of the stations are shown in Figures 4-10 and 4-11, respectively. 
Figure 4-9. Liquid Effluent Sampling Locations for Radionuclides

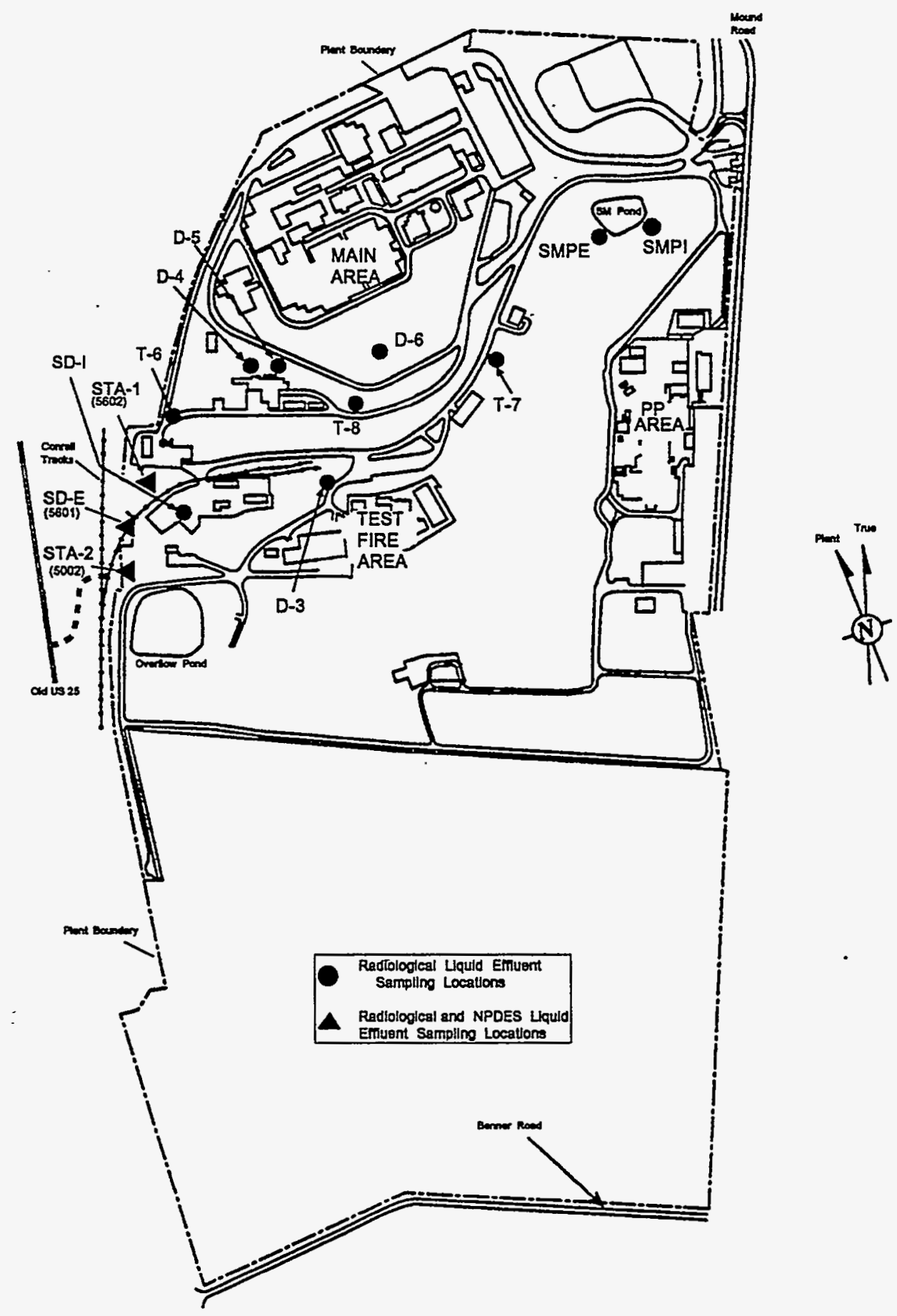


Table 4-2. Environmental Concentrations of Radionuclides in Sample Media in 1993

\begin{tabular}{|c|c|c|}
\hline Radionuclide & Average Concentration $a, b$ & Unit of Measure \\
\hline \multicolumn{3}{|l|}{ Ambient airc } \\
\hline Tritium oxide & $12.23 \pm 14.2$ & $10^{-12} \mu \mathrm{Ci} / \mathrm{mL}$ \\
\hline Plutonium-238 & $0.07 \pm 0.12$ & $10^{-18} \mu \mathrm{Ci} / \mathrm{mL}$ \\
\hline Plutonium-239,240 & $0.09 \pm 0.09$ & $10^{-18} \mu \mathrm{Ci} / \mathrm{mL}$ \\
\hline \multicolumn{3}{|l|}{ River waterd } \\
\hline Tritium & N.D. & \\
\hline Plutonium-238 & N.D. & \\
\hline Plutonium-239,240 & N.D. & \\
\hline Uranium-233,234 & $0.69 \pm 0.13$ & $10^{-9} \mu \mathrm{Ci} / \mathrm{mL}$ \\
\hline Uranium-238 & $0.64 \pm 0.13$ & $10^{-9} \mu \mathrm{Ci} / \mathrm{mL}$ \\
\hline \multicolumn{3}{|l|}{ Pond watere } \\
\hline Tritium & $0.05 \pm 0.22$ & $10^{-6} \mu \mathrm{Ci} / \mathrm{mL}$ \\
\hline Plutonium-238 & $0.11 \pm 1.45$ & $10^{-12} \mu \mathrm{Ci} / \mathrm{mL}$ \\
\hline Plutonium-239,240 & $0.32 \pm 1.24$ & $10^{-12} \mu \mathrm{Ci} / \mathrm{mL}$ \\
\hline \multicolumn{3}{|l|}{ Sediment } \\
\hline Plutonium-238 in river sediment ${ }^{d}$ & $0.82 \pm 1.81$ & $10^{-9} \mu \mathrm{Ci} / \mathrm{g}$ \\
\hline Plutonium-238 in pond sediment ${ }^{\Theta}$ & $2.35 \pm 3.95$ & $10^{-9} \mu \mathrm{Ci} / \mathrm{g}$ \\
\hline Plutonium-239,240 in river sediment ${ }^{d}$ & $2.17 \pm 1.69$ & $10^{-9} \mu \mathrm{Ci} / \mathrm{g}$ \\
\hline Plutonium-239,240 in pond sediment ${ }^{\ominus}$ & $5.05 \pm 6.38$ & $10^{-9} \mu \mathrm{Ci} / \mathrm{g}$ \\
\hline \multicolumn{3}{|l|}{ Vegetation ${ }^{t}$} \\
\hline Tritium in grass & $0.07 \pm 0.09$ & $10^{-6} \mu \mathrm{Ci} / \mathrm{g}$ \\
\hline Plutonium-238 in grass & $0.03 \pm 0.04$ & $10^{-9} \mu \mathrm{Ci} / \mathrm{g}$ \\
\hline Plutonium-239,240 in grass & $0.03 \pm 0.05$ & $10^{-9} \mu \mathrm{Ci} / \mathrm{g}$ \\
\hline \multicolumn{3}{|l|}{ Foodstuffs ${ }^{t}$} \\
\hline Tritium in tomatoes & $0.07 \pm 0.04$ & $10^{-6} \mu \mathrm{Ci} / \mathrm{g}$ \\
\hline Plutonium-238 in root crops & N.D. & \\
\hline Plutonium-239,240 in root crops & N.D. & \\
\hline Plutonium-238 in fish & $0.01 \pm 0.01$ & $10^{-9} \mu \mathrm{Ci} / \mathrm{g}$ \\
\hline Plutonium-239,240 in fish & $0.006 \pm 0.02$ & $10^{-9} \mu \mathrm{Ci} / \mathrm{g}$ \\
\hline
\end{tabular}

a Error limits are estimates of the standard error of the estimated means at the $95 \%$ confidence level.

b N.D. indicates concentrations below the reagent blanks.

c Measured $28 \mathrm{mi}(45 \mathrm{~km})$ northwest of Mound.

d Measured $20 \mathrm{mi}(32 \mathrm{~km})$ upstream of Mound on the Great Miami River.

e Measured $38 \mathrm{mi}(61 \mathrm{~km})$ southeast of Mound.

f Measured $40 \mathrm{mi}(64 \mathrm{~km})$ west of Mound. 
Figure 4-10. Onsite Air Sampling Locations

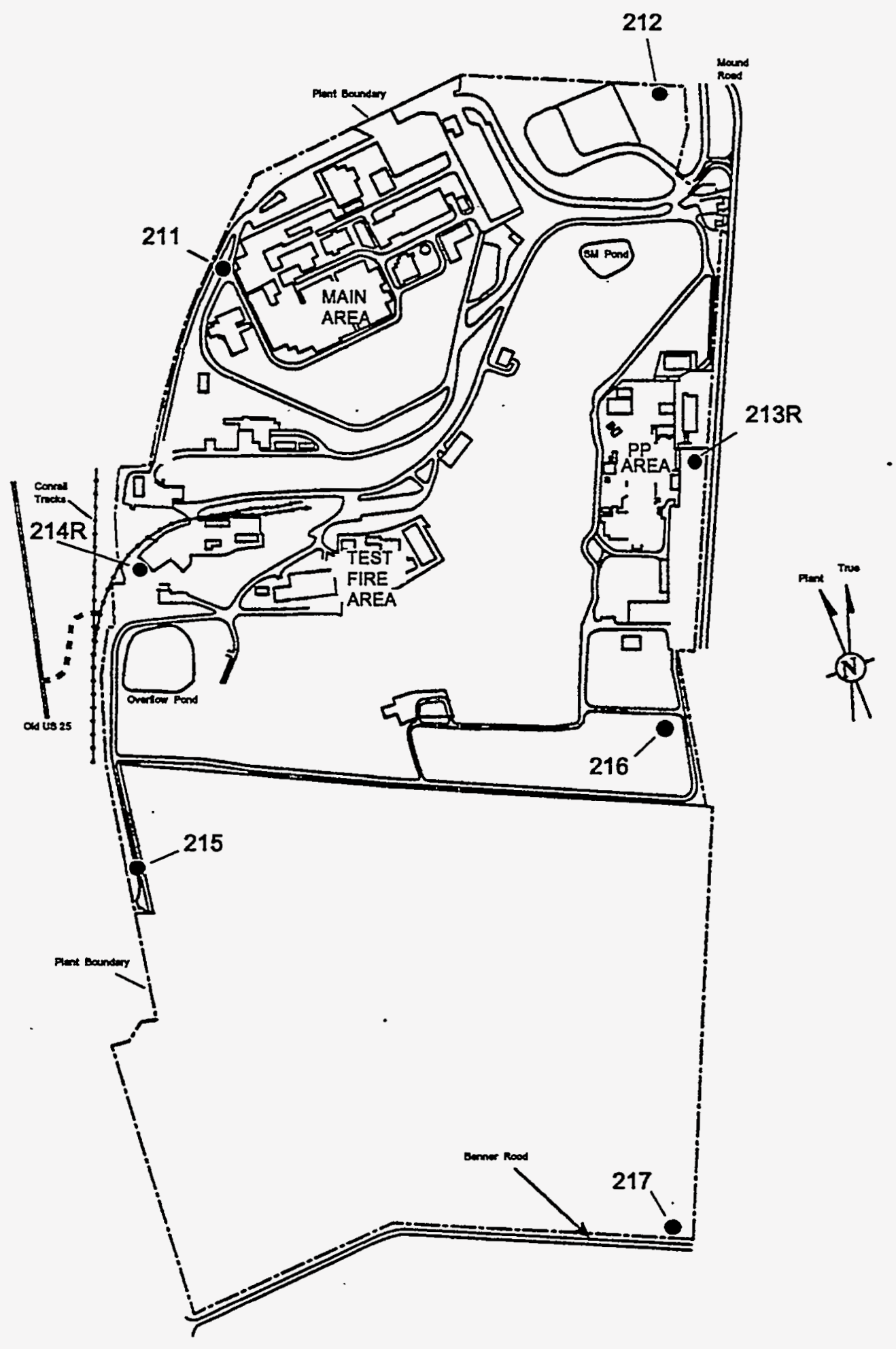


Figure 4-11. Offsite Air Sampling Locations

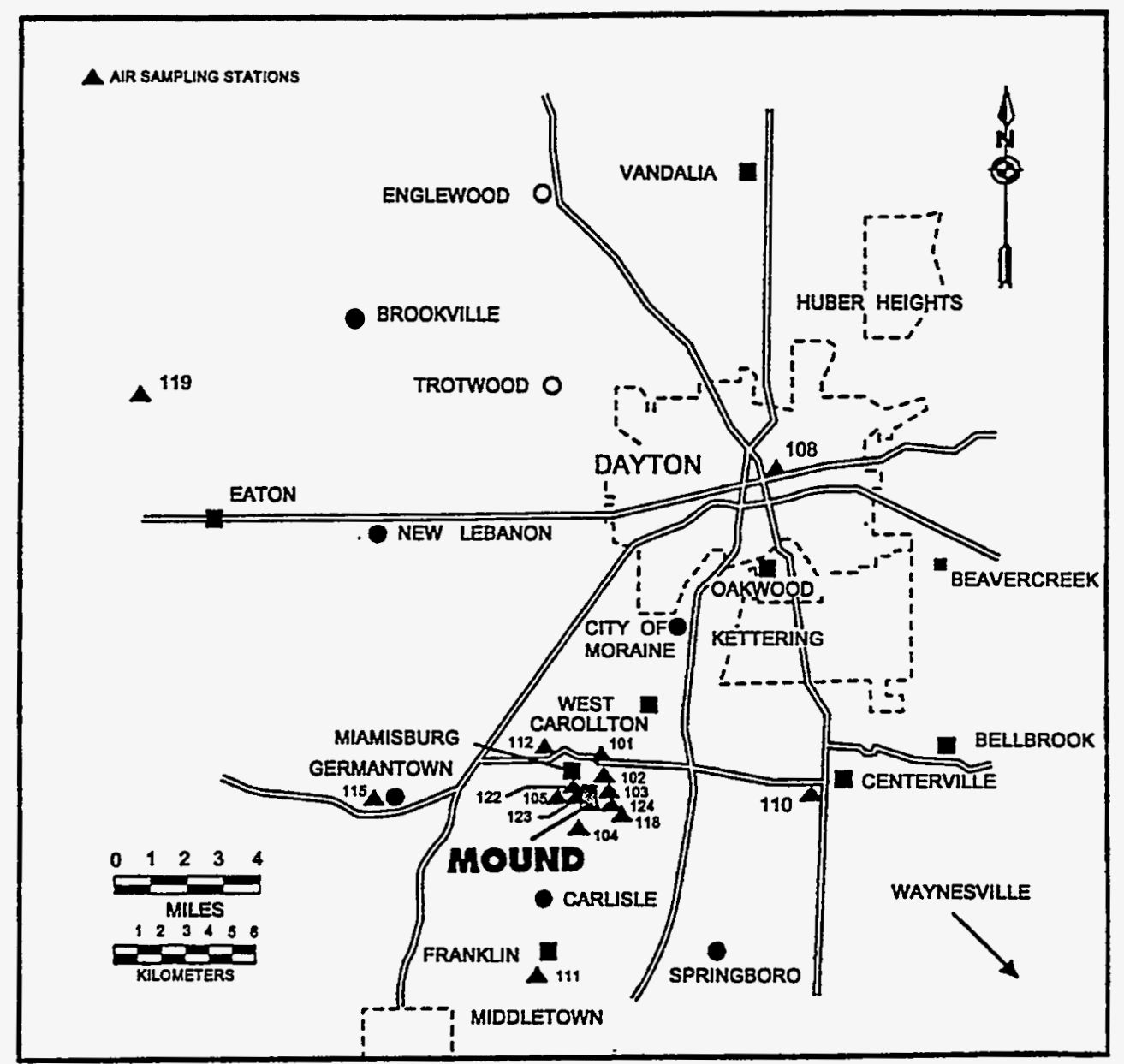

Tritium. The air sample for tritium analysis is collected on a continuous basis. Air is bubbled through $200 \mathrm{~mL}$ of ethylene glycol at a flow rate of approximately $1000 \mathrm{~cm}^{3} / \mathrm{min}$. Ethylene glycol is used as the trapping solution because it is not subject to loss by evaporation and will not freeze when exposed to winter sampling conditions (Sheehan et al., 1975). The glycol solutions are changed weekly and represent a sample volume of approximately $10 \mathrm{~m}^{3}$ of air. An aliquot of each glycol solution is then analyzed weekly in a liquid scintillation counter.

With this technique, tritium oxide rather than elemental tritium is collected. This approach is appropriate because tritium oxide is the more radiotoxic form of tritium. The dose that would result from a given release of tritium oxide would be 25,000 times greater than the dose from the same number of curies of elemental tritium. 


\section{Radiological Environmental Program Information}

Plutonium. The particulate sample for isotopic plutonium analysis is collected on a $200-\mathrm{mm}$ diameter fiber glass disc by a continuously operating high-volume air sampler. The air is sampled at an average rate of $1.3 \times 10^{6} \mathrm{~cm}^{3} / \mathrm{min}$ (45 $\left.\mathrm{ft}^{3} / \mathrm{min}\right)$. The disc is changed weekly and represents a sample volume of approximately $1300 \mathrm{~m}^{3}$ of air. Each sampler is equipped with a flow meter so that location-specific flow rates can be calculated.

Plutonium analyses are performed on monthly composite samples for each onsite location and for the three offsite stations within $1000 \mathrm{~m}$ of Mound. The remaining samples are composited for quarterly analysis. The analytical protocol for plutonium incorporates the following basic steps: use of an internal tracer, chemical treatment, separation of plutonium with anion exchange resin, and alpha spectrometry.

Uranium. As seen in Table 4-1, Mound includes isotopes of uranium in the release data for air. However, because the stackemissions of uranium233,234 and uranium-238 are so low and their contributions to dose are negligible, these radionuclides are not monitored at the environmental air sampling stations.

\section{Applicable Standards}

The guides for concentrations of radionuclides in air are given in DOE Order 5400.5 (DOE, 1990). These guides are based on recommendations in Publications 26 and 30 of the International Commission on Radiological Protection (ICRP 1977, 1979). The guides for radionuclide concentrations are referred to as Derived Concentration Guides, or DCGs. The DCG for a radionuclide is defined as the concentration of that radionuclide in air or water which will give a 50-year committed effective dose equivalent of $100 \mathrm{mrem}(1 \mathrm{mSv})$ if taken into the body by inhalation or ingestion. DCGs for tritium, plutonium-238 in air, and plutonium-239,240 in air are listed in Tables 4-3, 4-4, and 4-5, respectively.

\section{Results for 1993}

Radionuclide concentrations measured at environmental air sampling stations in 1993 are shown in Tables 4-3, 4-4, and 4-5. The results are also presented in terms of the percentage DCG they represent. As seen from the tables, air concentrations of tritium and plutonium measured on and about Mound consistently averaged less than $0.03 \%$ of the DCGs established for those radionuclides.

\subsection{Surface Water and Sediment Sampling Program}

The Great Miami River and other regional surface waters are sampled routinely by Mound for tritium, isotopes of plutonium, and isotopes of uranium. Sediment samples are also collected from these locations and analyzed for plutonium isotopes. Sampling locations are shown in Figure 4-12. The analytical procedures followed for these samples are consistent with the descriptions presented in Section 4.2 of this report.

Great Miami River. River sampling locations have been selected-according to guidelines published by the DOE (DOE 1991, 1992). These locations provide samples that are representative of river water after considerable mixing with Mound effluents has occurred. Tritium samples are collected and analyzed weekly; plutonium238, plutonium-239,240, uranium-233,234, and uranium-238 samples are collected and analyzed monthly. • 
Table 4-3. Incremental Concentrations ${ }^{a}$ of Tritium Oxide in Air in 1993

\begin{tabular}{|c|c|c|c|c|c|}
\hline Location* & $\begin{array}{l}\text { Number } \\
\text { of } \\
\text { Samples }\end{array}$ & Minimum & $\begin{array}{l}\text { Tritium Oxide } \\
10^{-12} \mu \mathrm{Ci} / \mathrm{mL} \\
\text { Maximum }\end{array}$ & $\overline{\text { Average }^{b}, c}$ & $\begin{array}{l}\text { Average as a } \\
\text { percent of } \\
\text { DOE DCGd }\end{array}$ \\
\hline \multicolumn{6}{|l|}{ Offsite } \\
\hline 101 & 51 & e & 188.92 & $3.38 \pm 17.70$ & 0.003 \\
\hline 102 & 51 & $e$ & 202.45 & $4.40 \pm 18.37$ & 0.004 \\
\hline 103 & 50 & $e$ & 226.90 & $1.19 \pm 19.13$ & 0.001 \\
\hline 104 & 51 & e & 201.15 & e & $e$ \\
\hline 105 & 49 & $e$ & 217.19 & e & e \\
\hline 108 & 51 & $e$ & 252.41 & e & e \\
\hline 110 & 51 & e & 210.32 & e & e \\
\hline 111 & 51 & e & 264.65 & e & e \\
\hline 112 & 50 & e & 199.57 & $e$ & $e$ \\
\hline 115 & 51 & e & 218.53 & $e$ & $e$ \\
\hline 118 & 49 & e & 203.49 & $1.29 \pm 18.72$ & 0.001 \\
\hline 122 & 51 & e & 227.59 & $1.15 \pm 19.02$ & 0.001 \\
\hline 123 & 52 & e & 245.60 & $4.82 \pm 19.42$ & 0.005 \\
\hline 124 & 50 & e & 176.27 & $2.00 \pm 17.51$ & 0.002 \\
\hline \multicolumn{6}{|l|}{ Onsite } \\
\hline 211 & 50 & e & 205.40 & $6.76 \pm 18.18$ & 0.007 \\
\hline 212 & 50 & e & 192.47 & $5.45 \pm 18.05$ & 0.006 \\
\hline $213 R$ & 52 & e & 183.54 & $4.43 \pm 17.56$ & 0.005 \\
\hline $214 R$ & 51 & e & 223.44 & $3.88 \pm 18.21$ & 0.004 \\
\hline 215 & 52 & e & 179.96 & $1.20 \pm 17.43$ & 0.001 \\
\hline 216 & 52 & e & 195.66 & $1.31 \pm 17.99$ & 0.001 \\
\hline 217 & 51 & e & 186.20 & $e$ & $e$ \\
\hline
\end{tabular}

a Average environmental level shown in Table 4-2 subtracted from the data.

b Error limits are estimates of the standard error of the estimated means at the $95 \%$ confidence level.

c LDL for tritium oxide in air is $19 \times 10^{-12} \mu \mathrm{Ci} / \mathrm{mL}$.

d DOE DCG for tritium oxide in air is $100,000 \times 10^{-12} \mu \mathrm{Ci} / \mathrm{mL}$.

e Below environmental level.

* Offsite sampling locations shown on Figure 4-11.

Onsite sampling locations shown on Figure 4-10. 
Table 4-4. Incremental Concentrations ${ }^{a}$ of Plutonium-238 in Air in 1993

\begin{tabular}{|c|c|c|c|c|c|}
\hline Location* & $\begin{array}{l}\text { Number } \\
\text { of } \\
\text { Samples }\end{array}$ & $\overline{\text { Minimum }}$ & $\begin{array}{l}\text { Plutonium-238 } \\
10^{-18} \mu \mathrm{Ci} / \mathrm{mL} \\
\text { Maximum }\end{array}$ & $\frac{8}{\text { Average }^{b, c}}$ & $\begin{array}{l}\text { Average as a } \\
\text { percent of } \\
\text { DOE DCGd }\end{array}$ \\
\hline \multicolumn{6}{|l|}{ Offsite } \\
\hline 101 & 4 & 0.65 & 24.08 & $7.01 \pm 18.12$ & 0.02 \\
\hline 102 & 4 & 1.51 & 7.63 & $3.76 \pm 4.61$ & 0.01 \\
\hline 103 & 4 & 1.66 & 4.56 & $3.22 \pm 2.01$ & 0.01 \\
\hline 104 & 4 & 0.56 & 6.63 & $2.19 \pm 4.72$ & 0.007 \\
\hline 105 & 3 & 0.48 & 1.76 & $1.19 \pm 1.62$ & 0.004 \\
\hline 108 & 4 & $e$ & 0.06 & e & e \\
\hline 110 & 4 & e & 0.04 & e & e \\
\hline 111 & 4 & 0.02 & 0.48 & $0.15 \pm 0.37$ & 0.0005 \\
\hline 112 & 4 & 0.06 & 0.31 & $0.18 \pm 0.23$ & 0.0006 \\
\hline 115 & 4 & $e$ & 0.58 & $0.11 \pm 0.52$ & 0.0004 \\
\hline 118 & 4 & 0.63 & 3.28 & $1.95 \pm 1.88$ & 0.007 \\
\hline 122 & 12 & 0.29 & 2.53 & $1.07 \pm 0.41$ & 0.004 \\
\hline 123 & 12 & 2.00 & 12.13 & $5.90 \pm 1.82$ & 0.02 \\
\hline 124 & 12 & 0.62 & 27.55 & $6.52 \pm 4.72$ & 0.02 \\
\hline \multicolumn{6}{|l|}{ Onsite } \\
\hline 211 & 12 & 2.16 & 13.11 & $6.04 \pm 2.18$ & 0.02 \\
\hline 212 & 12 & 1.21 & 24.57 & $8.51 \pm 4.36$ & 0.03 \\
\hline $213 R$ & 12 & 10.86 & 86.49 & $41.45 \pm 16.19$ & 0.14 \\
\hline $214 R$ & 12 & 1.03 & 18.54 & $7.10 \pm 2.76$ & 0.02 \\
\hline 215 & 12 & 1.41 & 6.60 & $3.41 \pm 1.09$ & 0.01 \\
\hline 216 & 12 & 2.35 & 117.49 & $21.61 \pm 23.02$ & 0.07 \\
\hline 217 & 12 & 0.58 & 12.93 & $2.78 \pm 2.25$ & 0.009 \\
\hline
\end{tabular}

a Average environmental level shown in Table 4-2 subtracted from the data.

b Error limits are estimates of the standard error of the estimated means at tha $95 \%$ confidence level.

c $\mathrm{LDL}$ for monthly values is $0.2 \times 10^{-18} \mu \mathrm{Ci} / \mathrm{mL}$; for quarterly values the $L D L$ is $0.06 \times 10^{-18} \mu \mathrm{Ci} / \mathrm{mL}$.

$\mathrm{d}$ DOE DCG for plutonium-238 in air is $30,000 \times 10^{-18} \mu \mathrm{Ci} / \mathrm{mL}$.

e Below environmental level.

* Offsite sampling locations shown on Figure 4-11.

Onsite sampling locations shown on Figure 4-10. 
Table 4-5. Incremental Concentrations ${ }^{a}$ of Plutonium-239,240 in Air in 1993

\begin{tabular}{|c|c|c|c|c|c|}
\hline \multirow[b]{2}{*}{ Location* } & \multirow{2}{*}{$\begin{array}{l}\text { Number } \\
\text { of } \\
\text { Samples }\end{array}$} & \multicolumn{3}{|c|}{$\begin{array}{l}\text { Plutonium-239,240 } \\
10^{-18} \mu \mathrm{Ci} / \mathrm{mL}\end{array}$} & \multirow{2}{*}{$\begin{array}{l}\text { Average as a } \\
\text { percent of } \\
\text { DOE DCGd }\end{array}$} \\
\hline & & Minimum & Maximum & Average ${ }^{b, c}$ & \\
\hline \multicolumn{6}{|l|}{ Offsite } \\
\hline 101 & 4 & $e$ & 0.05 & e & $e$ \\
\hline 102 & 4 & 0.03 & 0.30 & $0.19 \pm 0.23$ & 0.001 \\
\hline 103 & 4 & $e$ & 0.34 & $0.12 \pm 0.32$ & 0.0006 \\
\hline 104 & 4 & 0.01 & 0.63 & $0.19 \pm 0.48$ & 0.001 \\
\hline 105 & 3 & e & 0.18 & $0.10 \pm 0.24$ & 0.0005 \\
\hline 108 & 4 & 0.03 & 0.41 & $0.15 \pm 0.29$ & 0.0008 \\
\hline 110 & 4 & $\mathrm{e}$ & 0.75 & $0.14 \pm 0.65$ & 0.0007 \\
\hline 111 & 4 & $e$ & 0.06 & $0.03 \pm 0.10$ & 0.0002 \\
\hline 112 & 4 & 0.03 & 0.08 & $0.05 \pm 0.10$ & 0.0003 \\
\hline 115 & 4 & e & 0.08 & $0.03 \pm 0.13$ & 0.0002 \\
\hline 118 & 4 & $e$ & 0.38 & $0.08 \pm 0.33$ & 0.0004 \\
\hline 122 & 12 & $e$ & 0.71 & $0.15 \pm 0.17$ & 0.0008 \\
\hline 123 & 12 & $e$ & 0.77 & $0.24 \pm 0.18$ & 0.001 \\
\hline 124 & 12 & $e$ & 0.51 & $0.22 \pm 0.15$ & 0.001 \\
\hline \multicolumn{6}{|l|}{ Onsite } \\
\hline 211 & 12 & $e$ & 1.78 & $0.38 \pm 0.31$ & 0.002 \\
\hline 212 & 12 & $e$ & 1.82 & $0.58 \pm 0.36$ & 0.003 \\
\hline $213 R$ & 12 & 0.17 & 4.18 & $1.33 \pm 0.79$ & 0.007 \\
\hline $214 R$ & 12 & e & 1.12 & $0.39 \pm 0.26$ & 0.002 \\
\hline 215 & 12 & $e$ & 0.96 & $0.30 \pm 0.22$ & 0.002 \\
\hline 216 & 12 & 0.08 & 6.60 & $1.15 \pm 1.23$ & 0.006 \\
\hline 217 & 12 & $e$ & 1.26 & $0.26 \pm 0.26$ & 0.001 \\
\hline
\end{tabular}

a Average environmental level shown in Table 4-2 subtracted from the data.

b Error limits are estimates of the standard error of the estimated means at the $95 \%$ confidence level.

c LDL for monthly values is $0.2 \times 10^{-18} \mu \mathrm{Ci} / \mathrm{mL}$; for quarterly values the $L D L$ is $0.08 \times 10^{-18} \mu \mathrm{Ci} / \mathrm{mL}$.

d DOE DCG for plutonium-239,240 in air is $20,000 \times 10^{-18} \mu \mathrm{Ci} / \mathrm{mL}$.

e Below environmental level.

* Offsite sampling locations shown on Figure 4-11. Onsite sampling locations shown on Figure 4-10. 
Figure 4-12. Sampling Locations for River Water, Ponds, and Sediment

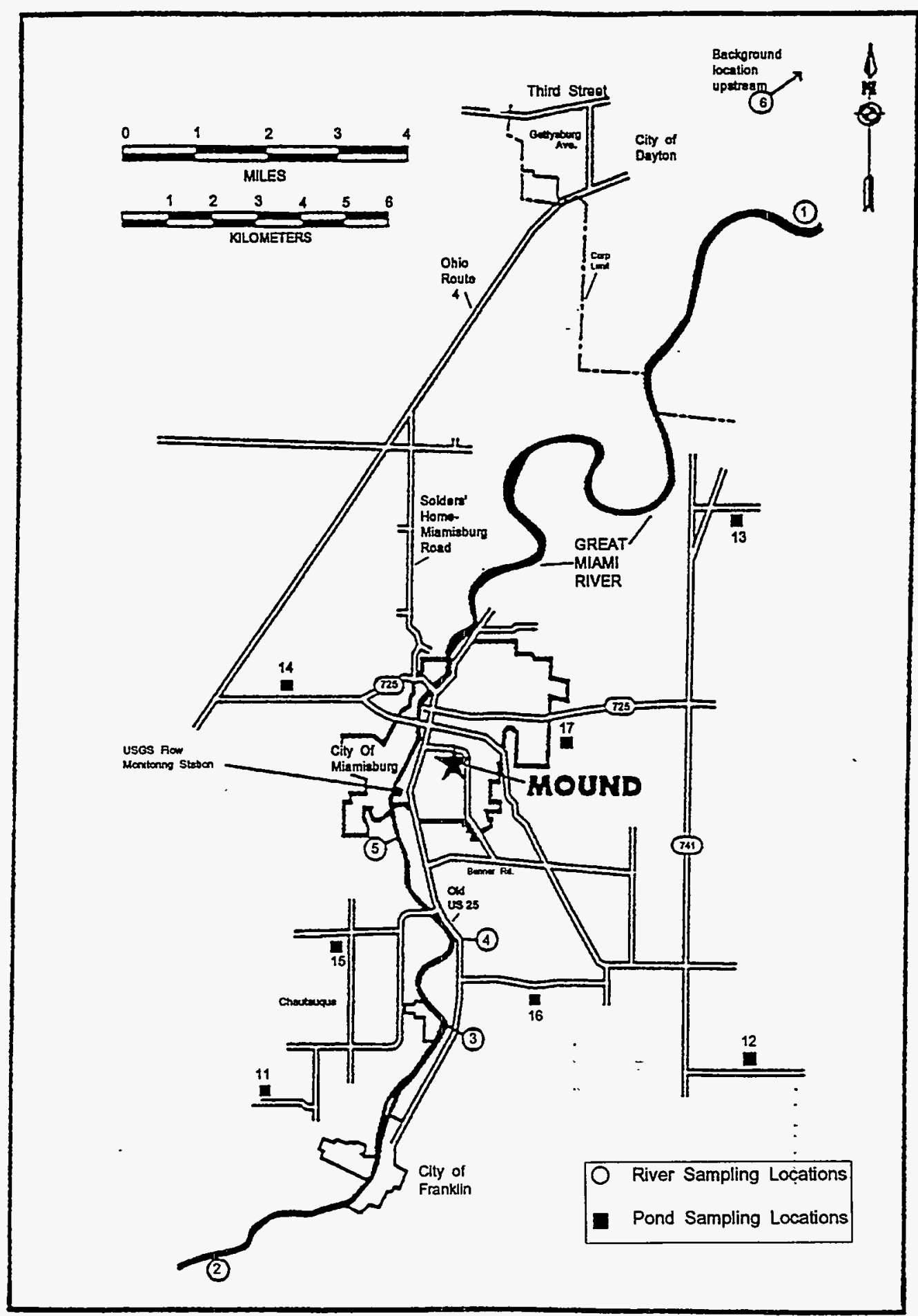




\section{Chapter 4}

Regional surface waters. Seven ponds in various compass sectors relative to Mound are sampled quarterly. These samples are analyzed for tritium, plutonium-238, and plutonium-239,240.

River and pond sediments. Many plutonium solutions, including those in use at Mound, are relatively insoluble in water. For this reason, they are more likely to be found in sediment than in surface water. Additionally, because of the relatively long half-lives of plutonium isotopes, they may accumulate in sediments over a number of years. Therefore, Mound samples river and pond sediments on a quarterly basis. These samples are then analyzed for plutonium-238 and plutonium-239,240.

\section{Applicable Standards}

DOE Order 5400.5 established a radiation dose limit for the general public of $100 \mathrm{mrem} / \mathrm{yr}(1.0$ $\mathrm{mSv}$ ) effective dose equivalent (EDE) for all exposure pathways. To ensure that the dose standard would not be exceeded, the Order also established derived concentration guides (DCGs). DCGs are those concentrations, that under conditions of continuous exposure for one year, would result in an EDE of 100 mrem.

The primary use of DCGs for liquid releases is to control exposures received from drinking water supplies. Since neitherthe GreatMiami Rivernor any of the regional ponds are sources of drinking water, the DCGs do not apply to the environmental data reported in this section. DCGs are listed in the tables of results to help put the values in perspective. For the sediments samples, however, there are no DCGs or other applicable standards.

\section{Results for 1993}

River water. Radionuclide concentrations in the Great Miami River are shown in Tables 4-6 through 4-9. Many tritium, plutonium, and uranium measurements were below their respective reagent blanks or environmental levels. Averages for 1993 were on the order of one onethousandth of a DCG or less.

Pond water. Radionuclide concentrations measured in pond water are shown in Tables 4-10 through 4-12. As observed for the river samples, many of the pond results were below environmental levels or reagent blanks.

Sediment. Results for river and pond sediment are listed in Tables 4-13 and 4-14 for plutonium238 and plutonium-239,240, respectively. Maximum and average concentrations of plutonium for 1993 are comparable to concentrations observed in previous years. With two exceptions, slight increases and decreases were recorded with no evidence of an upward or downward trend. The exceptions involve Locations 4 and 5. Sediment results at those points continue to be elevated relative to the other sampling locations. Since Locations 4 and 5 are downstream of Mound, it is possible that some accumulation of plutonium-238 is occurring. The levels are still quite low and pose no significant risk, yet increased monitoring of this location may be warranted. 
Table 4-6. Concentrations ${ }^{a}$ of Tritium in the Great Miami River in 1993

\begin{tabular}{cccccc}
\hline & $\begin{array}{c}\text { Number } \\
\text { of } \\
\text { Samples }\end{array}$ & \multicolumn{3}{c}{$\begin{array}{c}\text { Tritium } \\
10^{-6} \mu \mathrm{Ci} / \mathrm{mL}\end{array}$} & $\begin{array}{c}\text { Average as a } \\
\text { percent of } \\
\text { LOE DCGd }\end{array}$ \\
\hline 1 & 52 & $\mathrm{e}$ & 0.13 & $\mathrm{e}$ & $\mathrm{e}$ \\
2 & 52 & $\mathrm{e}$ & 0.12 & $\mathrm{e}$ & $\mathrm{e}$ \\
3 & 52 & $\mathrm{e}$ & 0.13 & $\mathrm{e}$ & $\mathrm{e}$ \\
4 & 52 & $\mathrm{e}$ & 0.24 & $\mathrm{e}$ & $\mathrm{e}$ \\
5 & 52 & $\mathrm{e}$ & 0.25 & $\mathrm{e}$ & $\mathrm{e}$ \\
\hline
\end{tabular}

a The environmental level was less than the reagent blank; therefore, the data have not been labelled incremental concentrations.

b Error limits are estimates of the standard error of the estimated means at the $95 \%$ confidence level.

$c$ LDL for tritium in water is $0.7 \times 10^{-6} \mu \mathrm{Ci} / \mathrm{mL}$.

d DOE DCG for tritium in water is $2,000 \times 10^{-6} \mu \mathrm{Ci} / \mathrm{mL}$.

Below reagent blank.

- Sampling locations shown on Figure 4-12.

Table 4-7. Concentrations ${ }^{a}$ of Plutonium-238 in the Great Miami River in 1993

\begin{tabular}{|c|c|c|c|c|c|}
\hline Location* & $\begin{array}{l}\text { Number } \\
\text { of } \\
\text { Samples }\end{array}$ & Minimum & $\begin{array}{l}\text { Plutonium-238 } \\
\frac{10^{-12} \mu \mathrm{Ci} / \mathrm{mL}}{\text { Maximum }}\end{array}$ & Averageb,c & $\begin{array}{l}\text { Average as a } \\
\text { percent of } \\
\text { DOE DCGd }\end{array}$ \\
\hline 1 & 12 & e & 17.68 & $1.71 \pm 3.27$ & 0.004 \\
\hline 2 & 12 & e & 4.23 & $0.28 \pm 0.96$ & 0.0007 \\
\hline 3 & 12 & e & 1.47 & $\mathrm{e}$ & $e$ \\
\hline 4 & 11 & e & 3.98 & $0.72 \pm 1.39$ & 0.002 \\
\hline 5 & 12 & e & 2.50 & e & e \\
\hline \multicolumn{6}{|c|}{$\begin{array}{l}\text { The environmental level was less than the reagent blank; therefore the data have not been labelled } \\
\text { incremental concentrations. } \\
\text { b Error limits are estimates of the standard error of the estimated means at the } 95 \% \text { confidence level. } \\
\text { c LDL for plutonium- } 238 \text { in river water is } 4.0 \times 10^{-12} \mu \mathrm{Ci} / \mathrm{mL} \text {. } \\
\text { d DOE DCG for plutonium- } 238 \text { in water is } 40,000 \times 10^{-12} \mu \mathrm{Ci} / \mathrm{mL} \text {. } \\
\text { e Below reagent blank. } \\
\text { * Sampling locations shown on Figure } 4-12 \text {. }\end{array}$} \\
\hline
\end{tabular}


Table 4-8. Concentrations ${ }^{a}$ of Plutonium-239,240 in the Great Miami River in 1993

\begin{tabular}{cccccc}
\hline & $\begin{array}{c}\text { Number } \\
\text { of } \\
\text { Location* } \\
\text { Samples }\end{array}$ & \multicolumn{3}{c}{$\begin{array}{c}\text { Plutonium-239,240 } \\
10^{-12} \mu \mathrm{Ci} / \mathrm{mL}\end{array}$} & $\begin{array}{c}\text { Average as a } \\
\text { percent of } \\
\text { DOE DCGd }\end{array}$ \\
\cline { 3 - 6 } & 12 & $e$ & 5.40 & $0.62 \pm 1.33$ & 0.002 \\
2 & 12 & $e$ & 4.45 & $0.63 \pm 1.29$ & 0.002 \\
3 & 12 & $e$ & 2.20 & $e$ & $e$ \\
4 & 11 & $e$ & 3.75 & $e$ & $e$ \\
5 & 12 & $e$ & 0.70 & $e$ & $e$ \\
\hline
\end{tabular}

a The environmental level was less than the reagent blank; therefore the data have not been labelled incremental concentrations.

b Error limits are estimates of the standard error of the estimated means at the $95 \%$ confidence level.

C $L D L$ for plutonium-239 in river water is $6.0 \times 10^{-12} \mu \mathrm{Ci} / \mathrm{mL}$.

d DOE DCG for plutonium-239 in water is $30,000 \times 10^{-12} \mu \mathrm{Ci} / \mathrm{mL}$.

Q Below reagent blank.

" Sampling locations shown on Figure 4-12. 
Table 4-9. Incremental Concentrations ${ }^{a}$ of Uranium-233,234 and Uranium-238 in the Great Miami River in 1993

\begin{tabular}{|c|c|c|c|c|c|}
\hline \multirow[b]{2}{*}{ Location* } & \multirow{2}{*}{$\begin{array}{l}\text { Number } \\
\text { of } \\
\text { Samples }\end{array}$} & \multicolumn{3}{|c|}{$\begin{array}{c}\text { Uranium-233,234 } \\
10^{-9} \mu \mathrm{Ci} / \mathrm{mL}\end{array}$} & \multirow{2}{*}{$\begin{array}{l}\text { Average as a } \\
\text { percent of } \\
\text { DOE DCGd }\end{array}$} \\
\hline & & Minimum & Maximum & Average ${ }^{b, c}$ & \\
\hline 1 & 12 & e & 0.39 & $0.10 \pm 0.18$ & 0.02 \\
\hline 2 & 12 & $e$ & 0.14 & e & e \\
\hline 3 & 12 & e & 0.16 & $0.03 \pm 0.16$ & 0.006 \\
\hline 4 & 12 & e & 0.13 & $0.02 \pm 0.16$ & 0.004 \\
\hline 5 & 12 & e & 0.19 & $0.03 \pm 0.16$ & 0.006 \\
\hline Location* & $\begin{array}{l}\text { Number } \\
\text { of } \\
\text { Samoles }\end{array}$ & \multicolumn{3}{|c|}{$\begin{array}{l}\text { Uranium-238 } \\
10^{-9} \mu \mathrm{Ci} / \mathrm{mL}\end{array}$} & $\begin{array}{l}\text { Average as a } \\
\text { percent of } \\
\text { DOF DCGd }\end{array}$ \\
\hline 1 & 12 & e & 0.29 & $0.09 \pm 0.17$ & 0.02 \\
\hline 2 & 12 & e & 0.18 & e & $e$ \\
\hline 3 & 12 & e & 0.17 & $0.03 \pm 0.15$ & 0.005 \\
\hline 4 & 12 & e & 0.20 & $0.02 \pm 0.16$ & 0.003 \\
\hline 5 & 12 & e & 0.17 & $0.03 \pm 0.16$ & 0.005 \\
\hline
\end{tabular}

average environmental level shown in Table 4-2 subtracted from the data.

b Error limits are estimates of the standard error of the estimated means at the $95 \%$ confidence level.

$c$ LDL for uranium-233,234 is $0.06 \times 10^{-9} \mu \mathrm{Ci} / \mathrm{mL}$. The LDL for uranium-238 is $0.02 \times 10^{-9} \mu \mathrm{Ci} / \mathrm{mL}$.

d DOE DCG for uranium-233,234 in water is $500 \times 10^{-9} \mu \mathrm{Ci} / \mathrm{mL}$. The DOE DCG for uranium-238 in water is $600 \times 10^{-9} \mu \mathrm{Ci} / \mathrm{mL}$.

e Below environmental level.

- Sampling locations shown on Figure 4-12. 
Table 4-10. Incremental Concentrations ${ }^{a}$ of Tritium in Pond Water in 1993

\begin{tabular}{|c|c|c|c|c|c|}
\hline Location* & $\begin{array}{l}\text { Number } \\
\text { of } \\
\text { Samnles }\end{array}$ & Minimim & $\begin{array}{c}\text { Tritium } \\
10^{-6} \mu \mathrm{Ci} / \mathrm{mL}\end{array}$ & Avaragob.c & $\begin{array}{l}\text { Average as a } \\
\text { percent of }\end{array}$ \\
\hline 11 & 4 & $e$ & 0.04 & $e$ & e \\
\hline 12 & 4 & e & 0.09 & e & e \\
\hline 13 & 3 & e & 0.06 & e & e \\
\hline 14 & 4 & $e$ & 0.07 & e & $\mathrm{e}$ \\
\hline 15 & 4 & e & 0.03 & $e$ & $e$ \\
\hline 17 & 4 & 0.02 & 0.10 & $0.06 \pm 0.22$ & 0.003 \\
\hline
\end{tabular}

a Average environmental level shown in Table 4-2 subtracted from the data.

b Error limits are estimates of the standard error of the estimated means at the $95 \%$ confidence level.

c LDL for tritium in water is $0.8 \times 10^{-6} \mu \mathrm{Ci} / \mathrm{mL}$.

d DOE DCG for tritium in water is $2,000 \times 10^{-6} \mu \mathrm{Ci} / \mathrm{mL}$.

$\theta$ Below environmental level.

* Sampling locations shown on Figure 4-12.

Table 4-11. Incremental Concentrations ${ }^{a}$ of Plutonium-238 in Pond Water in 1993

\begin{tabular}{|c|c|c|c|c|c|}
\hline Location* & $\begin{array}{l}\text { Number } \\
\text { of } \\
\text { Samples }\end{array}$ & Minimum & $\begin{array}{l}\text { Plutonium-23 } \\
10^{-12} \mu \mathrm{Ci} / \mathrm{mL} \\
\text { Maximum }\end{array}$ & $\frac{8}{\text { Average }^{b, c}}$ & $\begin{array}{l}\text { Average as a } \\
\text { percent of } \\
\text { DOE DCGd }\end{array}$ \\
\hline 11 & 4 & $e$ & 0.39 & $e$ & e \\
\hline 12 & 4 & e & e & e & e \\
\hline 13 & 3 & $e$ & 0.26 & $e$ & e \\
\hline 14 & 4 & $e$ & e & e & e \\
\hline 15 & 4 & e & 0.41 & e & e \\
\hline 17 & 4 & $e$ & 1.11 & $0.09 \pm 1.83$ & 0.0002 \\
\hline
\end{tabular}

a Average environmental level shown in Table 4-2 subtracted from the data.

b Error limits are estimates of the standard error of the estimated means at the $95 \%$ confidence level.

c LDL for plutonium-238 in water is $6.8 \times 10^{-12} \mu \mathrm{Ci} / \mathrm{mL}$.

d DOE DCG for plutonium-238 in water is $40,000 \times 10^{-12} \mu \mathrm{Ci} / \mathrm{mL}$.

e Below environmental level.

* Sampling locations shown on Figure 4-12. 
Table 4-12. Incremental Concentrations ${ }^{a}$ of Plutonium-239,240 in Pond Water in 1993

\begin{tabular}{|c|c|c|c|c|c|}
\hline \multirow[b]{2}{*}{ Location* } & \multirow{2}{*}{$\begin{array}{l}\text { Number } \\
\text { of } \\
\text { Samples }\end{array}$} & \multicolumn{3}{|c|}{$\begin{array}{l}\text { Plutonium- } 239,240 \\
10^{-12} \mu \mathrm{Ci} / \mathrm{mL}\end{array}$} & \multirow{2}{*}{$\begin{array}{l}\text { Average as a } \\
\text { percent of } \\
\text { DOE DCGd }\end{array}$} \\
\hline & & Minimum & Maximum & Averageb,c & \\
\hline 11 & 4 & e & 1.50 & $0.48 \pm 2.37$ & 0.002 \\
\hline 12 & 4 & e & 0.90 & e & $\dot{e}$ \\
\hline 13 & 3 & e & 0.75 & $e$ & e \\
\hline 14 & 4 & e & 6.75 & $1.37 \pm 6.0$ & 0.005 \\
\hline 15 & 4 & e & 0.19 & e & $e$ \\
\hline 17 & 4 & $e$ & $e$ & e & e \\
\hline
\end{tabular}

a Average environmental level shown in Table 4-2 subtracted from the data.

b Error limits are estimates of the standard error of the estimated means at the $95 \%$ confidence level.

C LDL for plutonium-239 in pond water is $4.5 \times 10^{-12} \mu \mathrm{Ci} / \mathrm{mL}$.

D DOE DCG for plutonium-239 in water is $30,000 \times 10^{-12} \mu \mathrm{Ci} / \mathrm{mL}$.

e Below environmental level.

* Sampling locations shown on Figure 4-12. 
Table 4-13. Incremental Concentrations ${ }^{a}$ of Plutonium-238 in River and Pond Sediments in 1993.

\section{River Sediment Sampling Locations}

\begin{tabular}{ccccc}
\hline & $\begin{array}{c}\text { Number } \\
\text { of } \\
\text { Samples }\end{array}$ & \multicolumn{3}{c}{$\begin{array}{c}\text { Plutonium-238 } \\
10^{-9} \mu \mathrm{Ci} / \mathrm{g}\end{array}$} \\
\cline { 3 - 5 } Socation $^{*}$ & 4 & $\mathrm{~d}$ & 24.61 & $6.17 \pm 19.65$ \\
1 & 4 & 7.15 & 46.23 & $21.27 \pm 27.82$ \\
2 & 4 & 0.01 & 36.54 & $18.35+24.16$ \\
3 & 4 & 34.23 & 85.54 & $58.13 \pm 42.69$ \\
4 & 4 & 3.02 & 278.20 & $72.86 \pm 217.82$ \\
5 & & & & Average ${ }^{b, c}$ \\
& & & &
\end{tabular}

\section{. Pond Sediment Sampling Locations}

\begin{tabular}{ccccc}
\hline & $\begin{array}{c}\text { Number } \\
\text { of } \\
\text { Location* }\end{array}$ & \multicolumn{3}{c}{$\begin{array}{c}\text { Plutonium-238 } \\
10^{-9} \mu \mathrm{Ci} / \mathrm{g}\end{array}$} \\
\cline { 3 - 5 } & Samples & Minimum & Maximum & Average, $\mathrm{c}^{\mathrm{b}}$ \\
\hline 11 & 4 & $\mathrm{~d}$ & $\mathrm{~d}$ & $\mathrm{~d}$ \\
12 & 4 & $\mathrm{~d}$ & $\mathrm{~d}$ & $\mathrm{~d}$ \\
13 & 3 & $\mathrm{~d}$ & $\mathrm{~d}$ & $\mathrm{~d}$ \\
14 & 4 & $\mathrm{~d}$ & 1.59 & $\mathrm{~d}$ \\
15 & 4 & $\mathrm{~d}$ & $\mathrm{~d}$ & $\mathrm{~d}$ \\
17 & 4 & 2.38 & 11.39 & $7.18 \pm 8.49$ \\
\hline
\end{tabular}

a Average environmental level shown in Table 4-2 subtracted from the data.

$b$ Error limits are estimates of the standard error of the estimated means at the $95 \%$ confidence level.

$c^{c}$ LDL for plutonium-238 in river sediment is $0.5 \times 10^{-9} \mu \mathrm{Ci} / \mathrm{g}$. LDL for plutonium-238 in pond sediment is $1.2 \times 10^{-9} \mu \mathrm{Ci} / \mathrm{g}$.

d Below environmental level.

* Sampling locations shown on Figure 4-12. 
Table 4-14. Incremental Concentrations ${ }^{\mathrm{a}}$ of Plutonium-239,240 in River and Pond Sediments in 1993

River Sediment Sampling Locations

\begin{tabular}{|c|c|c|c|c|}
\hline \multirow[b]{2}{*}{ Location* } & \multirow{2}{*}{$\begin{array}{l}\text { Number } \\
\text { of } \\
\text { Samples }\end{array}$} & \multicolumn{3}{|c|}{$\begin{array}{l}\text { Plutonium-239,240 } \\
10^{-9} \mu \mathrm{Ci} / \mathrm{g} \\
\end{array}$} \\
\hline & & Minimum & Maximum & Average $b, c$ \\
\hline 1 & 4 & $d$ & 3.37 & $1.14 \pm 3.67$ \\
\hline 2 & 4 & $d$ & 0.74 & $d$ \\
\hline 3 & 4 & $d$ & $d$ & $d$ \\
\hline 4 & 4 & $d$ & 6.44 & $1.56 \pm 5.73$ \\
\hline 5 & 4 & 0.26 & 20.92 & $6.49 \pm 15.50$ \\
\hline
\end{tabular}

Pond Sediment Sampling Locations

\begin{tabular}{ccccc}
\hline & $\begin{array}{c}\text { Number } \\
\text { of } \\
\text { Samples }\end{array}$ & \multicolumn{3}{c}{$\begin{array}{c}\text { Plutonium-239,240 } \\
10^{-9} \mu \mathrm{Ci} / \mathrm{g}\end{array}$} \\
\cline { 3 - 5 } Location* & Minimum & Maximum & Average b,c \\
\hline 11 & 4 & $\mathrm{~d}$ & 0.62 & $\mathrm{~d}$ \\
12 & 4 & $\mathrm{~d}$ & 1.71 & $\mathrm{~d}$ \\
13 & 3 & $\mathrm{~d}$ & $\mathrm{~d}$ & $\mathrm{~d}$ \\
14 & 4 & $\mathrm{~d}$ & $\mathrm{~d}$ & $\mathrm{~d}$ \\
15 & 4 & $\mathrm{~d}$ & $\mathrm{~d}$ & $\mathrm{~d}$ \\
17 & 4 & $\mathrm{~d}$ & $\mathrm{~d}$ & $\mathrm{~d}$ \\
\hline
\end{tabular}

a Average environmental level shown in Table 4-2 subtracted from the data.

b Error limits are estimates of the standard error of the estimated means at the $95 \%$ confidence level.

c LDL for plutonium-239 in river sediment is $0.5 \times 10^{-9} \mu \mathrm{Ci} / \mathrm{g}$. LDL for plutonium-239 in pond sediment is $0.6 \times 10^{-9} \mu \mathrm{Ci} / \mathrm{g}$.

d Below environmental level.

* Sampling locations shown on Figure 4-12. 


\subsection{Produce and Vegetation}

Various locally grown produce and vegetation samples are collected during the growing season from the surrounding area. Additionally, fish are collected from the Great Miami River. The intent of this aspect of the Environmental Monitoring Program at Mound is to determine whether significant concentrations of radionuclides are present in plant and animal life.

In 1993, samples of grass, rootcrops, and tomatoes were collected from a number of regional cities. Fish were collected from the river downstream of Mound's discharge points.

Plutonium concentrations are determined by ashing the samples, then proceeding with the technique used for plutonium analyses of airsamples (Section 4.4). Tritium concentrations are determined by removing and distilling the water from the sample, then analyzing the distillate using liquid scintillation spectrometry.

\section{Results for 1993}

The results for the produce, vegetation, and fish analyses are shown in Tables 4-15 through 4-17. As seen in the tables, most of the samples were below their respective environmental levels or reagent blanks. Only those cities in proximity to Mound had average concentrations that were positive. The results demonstrate that exposure to Mound's effluents via food-related pathways is negligible. 
Table 4-15. Incremental Concentrations ${ }^{a}$ of Tritium in Vegetation and Produce in 1993

\begin{tabular}{|c|c|c|c|c|c|}
\hline \multirow[b]{2}{*}{ Location" } & \multirow{2}{*}{$\begin{array}{c}\text { Type } \\
\text { of } \\
\text { Sample }\end{array}$} & \multirow{2}{*}{$\begin{array}{l}\text { Number } \\
\text { of } \\
\text { Samples }\end{array}$} & \multicolumn{3}{|c|}{$\begin{array}{c}\text { Tritium } \\
10^{-6} \mu \mathrm{Ci} / \mathrm{g}\end{array}$} \\
\hline & & & Minimum & Maximum & Average $b, c$ \\
\hline Bellbrook: & $\begin{array}{l}\text { Grass } \\
\text { Tomatoes }\end{array}$ & $\begin{array}{l}4 \\
4\end{array}$ & $\begin{array}{l}d \\
d\end{array}$ & $\begin{array}{l}0.03 \\
0.07\end{array}$ & $\begin{array}{c}d \\
0.04 \pm 0.07\end{array}$ \\
\hline Centerville & $\begin{array}{l}\text { Grass } \\
\text { Tomatoes }\end{array}$ & $\begin{array}{l}4 \\
4\end{array}$ & $\frac{0.22}{d}$ & $\begin{array}{c}0.31 \\
d\end{array}$ & $0.27 \pm 0.11$ \\
\hline Franklin & $\begin{array}{l}\text { Grass } \\
\text { Tomatoes }\end{array}$ & $\begin{array}{l}\dot{4} \\
4\end{array}$ & $\begin{array}{l}d \\
d\end{array}$ & $\begin{array}{l}0.24 \\
0.04\end{array}$ & $0.13 \pm 0.18$ \\
\hline Germantown & $\begin{array}{l}\text { Grass } \\
\text { Tomatoes }\end{array}$ & $\begin{array}{l}4 \\
4\end{array}$ & $\begin{array}{l}d \\
d\end{array}$ & $\begin{array}{l}0.10 \\
0.04\end{array}$ & $0.03 \pm 0.13$ \\
\hline Miamisburg & $\begin{array}{l}\text { Grass } \\
\text { Tomatoes }\end{array}$ & $\begin{array}{l}4 \\
4\end{array}$ & $\begin{array}{c}0.36 \\
d\end{array}$ & $\begin{array}{l}0.43 \\
0.06\end{array}$ & $\begin{array}{l}0.40 \pm 0.10 \\
0.03 \pm 0.08\end{array}$ \\
\hline Trotwood & $\begin{array}{l}\text { Grass } \\
\text { Tomatoes }\end{array}$ & $\begin{array}{l}4 \\
4\end{array}$ & $\begin{array}{c}d \\
0.05\end{array}$ & $\begin{array}{l}0.08 \\
0.09\end{array}$ & $\begin{array}{l}0.05 \pm 0.10 \\
0.06 \pm 0.06\end{array}$ \\
\hline
\end{tabular}

a Average environmental level shown in Table 4-2 subtracted from the data.

b Error limits are estimates of the standard error of the estimated means at the $95 \%$ confidence level.

c LDL for tritium in grass is $0.1 \times 10^{-6} \mu \mathrm{Ci} / \mathrm{g}$. For tritium in tomatoes, the LDL is $0.2 \times 10^{-6} \mu \mathrm{Ci} / \mathrm{g}$.

d Below environmental level.

- Community locations shown on Figure 4-11. 
Table 4-16. Concentrations ${ }^{a}$ of Plutonium-238 in Vegetation and Produce in 1993

\begin{tabular}{|c|c|c|c|c|c|}
\hline \multirow[b]{2}{*}{ Location" } & \multirow{2}{*}{$\begin{array}{c}\text { Type } \\
\text { of } \\
\text { Sample }\end{array}$} & \multirow{2}{*}{$\begin{array}{c}\text { Number } \\
\text { of } \\
\text { Samples }\end{array}$} & \multicolumn{3}{|c|}{$\begin{array}{l}\text { Plutonium-238 } \\
10^{-9} \mathrm{uCi} / \mathrm{q}\end{array}$} \\
\hline & & & Minimum & Maximum & Average $b, c$ \\
\hline \multirow[t]{2}{*}{ Bellbrook } & Grass & 4 & d & $d$ & d \\
\hline & Root crops & 4 & $\theta$ & e & e \\
\hline \multirow[t]{2}{*}{ Centerville } & Grass & 4 & $d$ & $d$ & $d$ \\
\hline & Root crops & 4 & 0.004 & 0.07 & $0.03 \pm 0.05$ \\
\hline \multirow[t]{2}{*}{ Franklin } & Grass & 4 & $d$ & 0.004 & d \\
\hline & Root crops & 4 & e & 0.04 & $0.02 \pm 0.03$ \\
\hline \multirow[t]{2}{*}{ Germantown } & Grass & 4 & $d$ & 0.04 & $d$ \\
\hline & Root crops & 4 & $\theta$ & 0.01 & $0.002 \pm 0.01$ \\
\hline \multirow[t]{2}{*}{ Miamisburg } & Grass & 4 & 0.10 & 0.36 & $0.23 \pm 0.17$ \\
\hline & Root crops & 4 & 0.01 & 0.09 & $0.04 \pm 0.06$ \\
\hline \multirow[t]{2}{*}{ Trotwood } & Grass & 4 & d & 0.07 & $0.02 \pm 0.06$ \\
\hline & Root crops & 4 & $e$ & 0.05 & $0.02 \pm 0.05$ \\
\hline $\begin{array}{l}\text { Great Miami } \\
\text { River }\end{array}$ & Fish & 4 & $d$ & $d$ & $d$ \\
\hline
\end{tabular}

a The average environmental level was less than the reagent blank for the root crop data. Therefore, those values have not been labelled "incremental" concentrations. For the grass data, the average environmental level (Table 4-2) was subtracted from the data; therefore, those values are "incremental" concentrations.

b Error limits are estimates of the standard error of the estimated means at the $95 \%$ confidence level.

c LDL for plutonium-238 in grass is $0.1 \times 10^{-9} \mu \mathrm{Ci} / \mathrm{g}$. For plutonium-238 in root crops, the $L D L$ is

$0.5 \times 10^{-9} \mu \mathrm{Ci} / \mathrm{g}$. For plutonium-238 in fish the $\mathrm{LDL}$ is $0.2 \times 10^{-9} \mu \mathrm{Ci} / \mathrm{g}$.

$\mathrm{d}$ Below environmental level.

$\Theta$ Below reagent blank.

* Community locations shown on Figure 4-11. 
Table 4-17. Concentrations ${ }^{a}$ of Plutonium-239,240 in Vegetation and Produce in 1993

\begin{tabular}{|c|c|c|c|c|c|}
\hline \multirow[b]{2}{*}{ Location* } & \multirow{2}{*}{$\begin{array}{c}\text { Type } \\
\text { of } \\
\text { Sample }\end{array}$} & \multirow{2}{*}{$\begin{array}{c}\text { Number } \\
\text { of } \\
\text { Samples }\end{array}$} & \multicolumn{3}{|c|}{$\begin{array}{c}\text { Plutonium-239,240 } \\
10^{-9} \mu \mathrm{Ci} / \mathrm{g} \\
\end{array}$} \\
\hline & & & Minimum & Maximum & Average $e^{b}, c$ \\
\hline \multirow[t]{2}{*}{ Bellbrook } & Grass & 4 & d & $d$ & $d$ \\
\hline & Root crops & 4 & $e$ & 0.08 & $0.03 \pm 0.06$ \\
\hline \multirow[t]{2}{*}{ Centerville } & Grass & 4 & $d$ & $d$ & $d$ \\
\hline & Root crops & 4 & 0.01 & 0.03 & $0.02 \pm 0.01$ \\
\hline \multirow[t]{2}{*}{ Franklin } & Grass & 4 & $d$ & $d$ & $d$ \\
\hline & Root crops & 4 & $e$ & 0.02 & $0.01 \pm 0.02$ \\
\hline \multirow[t]{2}{*}{ Germantown } & Grass & 4 & $d$ & 0.01 & d \\
\hline & Root crops & 4 & e & 0.04 & $0.02 \pm 0.03$ \\
\hline \multirow[t]{2}{*}{ Miamisburg } & Grass & 4 & $d$ & 0.12 & $0.03 \pm 0.10$ \\
\hline & Root crops & 4 & e & $e$ & $\theta$ \\
\hline \multirow[t]{2}{*}{ Trotwood } & Grass & 4 & $d$ & 0.02 & d \\
\hline & Root crops & 4 & $e$ & $e$ & $\theta$ \\
\hline $\begin{array}{l}\text { Great Miami } \\
\text { River }\end{array}$ & Fish & 4 & $d$ & 0.04 & $0.008 \pm 0.04$ \\
\hline
\end{tabular}

a The average environmental level was less than the reagent blank for the root crop data. Therefore, those values have not been labelled "incremental" concentrations. For the grass data, the average environmental level (Table 4-2) was subtracted from the data; therefore, those values are "incremental" concentrations.

b Error limits are estimates of the standard error of the estimated means at the $95 \%$ confidence level.

c LDL for plutonium-239 in grass is $0.2 \times 10^{-9} \mu \mathrm{Ci} / \mathrm{g}$. For plutonium-239 in root crops, the LDL is $0.6 \times 10^{-9} \mu \mathrm{Ci} / \mathrm{g}$. For plutonium-239 in fish the LDL is $0.03 \times 10^{-9} \mu \mathrm{Ci} / \mathrm{g}$.

$\mathrm{d}_{\text {Below environmental level. }}$

\& Below reagent blank.

- Community locations shown on Figure 4-11. 


\subsection{Offsite Dose Impacts}

\section{Dose Estimates Based on Measured Concentrations}

Mound used the data presented in this report to estimate maximum doses to an offsite individual. The figure-of-merit used to calculate those doses was the committed effective dose equivalent (CEDE). CEDE calculations are required of DOE facilities according to DOE Order 5400.1. These calculations are also useful in evaluating the success of ALARA (As Low As Reasonably Achievable) policies. It is the philosphy of Mound, and of the DOE complex as a whole, to ensure that all doses from radiation exposure remain ALARA.

To provide an extra degree of conservatism, dose estimates are often calculated based on maximum exposure conditions. This "maximumindividual", as defined for purposes of calculating CEDEs, is a hypothetical person who remained at the site boundary 24 hours per day throughout 1993 . This individual was assumed to have:
- continually breathed air containing the maximum radionuclide concentrations found at an onsite air sampling station,

- drawn all of his drinking water from the offsite well with the maximum radionuclide concentrations, and

- used offsite foods exhibiting the maximum radionuclide concentrations as components of his diet.

The radionuclides and the exposure pathways which contribute to the maximum individual's CEDEs are shown in Figure 4-13. Values for the CEDEs are shown in Table 4-18. More detailed information on the CEDE calculations, including the concentration values used, is presented in the Appendix.

Figure 4-13. Exposure Pathways for Dose Calculations Based on Measured Data for 1993

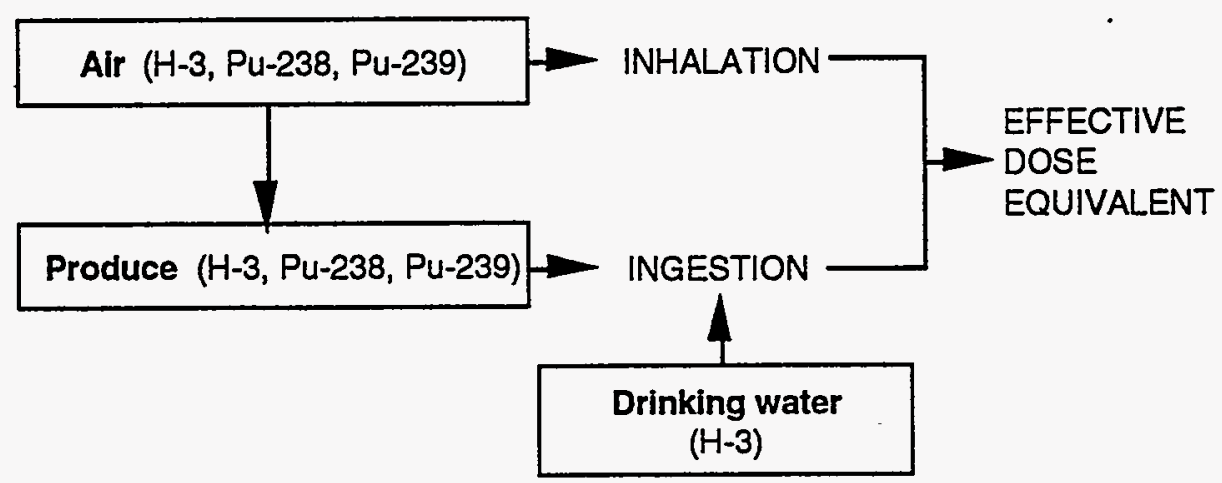


Table 4-18. Maximum Committed Effective Dose Equivalents to a Hypothetical Individual in 1993

\begin{tabular}{llll}
\hline Radionuclide & Pathway & mrem & mSV \\
\hline \multirow{2}{*}{ Tritium } & Air & 0.005 & 0.00005 \\
& Water & 0.04 & 0.0004 \\
& Produce & 0.004 & 0.00004 \\
\cline { 2 - 3 } & Total & 0.05 & 0.0005 \\
Plutonium-238 & Air & 0.13 & 0.0013 \\
& Produce & 0.07 & 0.0007 \\
\cline { 2 - 3 } & Total & 0.20 & 0.002 \\
& Air & 0.005 & 0.00005 \\
Plutonium-239 & Produce & 0.009 & 0.00009 \\
& Total & 0.01 & 0.0001 \\
& & & \\
& & 0.26 & 0.0026 \\
\hline
\end{tabular}

\section{Dose Estimates for NESHAPs Compliance}

The National Emission Standards for Hazardous Air Pollutants; Radionuclides regulations (NESHAPs; Radionuclides; 40 CFR 61, Subpart H) limit offsite doses from airborne releases to 10 mrem effective dose equivalent (EDE) per year. As specified by the EPA in 40 CFR 61, Subpart $H$, the preferred technique for demonstrating compliance with this dose standard is a modelled approach.

Maximum individual. Mound uses the EPA's ' computer code CAP-88 to evaluate doses for NESHAPs compliance. The 1993 input data for the CAP-88 calculations are listed in the Appendix. Based on the CAP-88 output, the maximum EDE from all airborne releases was $0.04 \mathrm{mrem}$. This estimate represents $0.4 \%$ of the dose standard.

Population doses. CAP- 88 also has the capability of estimating population doses from airborne releases. The population, approximately $3,035,000$ persons, within a radius of $80 \mathrm{~km}(50$ mi) of Mound received an estimated 2.1 personrem from Plant operations in 1993. CAP-88 determined this number by calculating average doses to individuals in areas defined by their distance and compass sector relative to the release point. The dose for each area was then multiplied by the number of people living there. For example, an average dose of $0.001 \mathrm{rem} \times 10,000$ persons in the area yields a 10 person-rem collective dose for that region.

Mound's dose contribution of 2.1 person-rem can be put in perspective by comparison with background doses. The average dose from background sources is 300 mrem $(0.3 \mathrm{rem})$ per individual per year. A background collective dose can be estimated for the $80-\mathrm{km}$ population by multiplying 0.3 rem $\times 3.035$ million persons. The result, about one million person-rem, represents an estimate of the collective dose from all background sources of ionizing radiation. Mound's contribution, 2.1 person-rem, is approximately $0.00021 \%$ of that value. 


\subsection{NONRADIOLOGICAL ENVIRONMENTAL PROGRAM INFORMATION}

The Mound Plant releases minor quantities of nonradiological constituents to the atmosphere. These releases are governed by State of Ohio permits. Mound monitors the impact of the Plant's nonradiological airborne releases by measuring airborne particulates at seven onsite and 15 offsite locations. Nonradiological liquid releases, however, are subject to much more extensive sampling protocols. Each year Mound collects over 1000 water samples to demonstrate compliance with the Site's National Pollutant Discharge Elimination System (NPDES) permit.

\subsection{Air Monitoring Program}

The primary source of nonradiological airborne emissions at Mound is the steam power plant. The plant is normally fueled with natural gas but under certain circumstances fuel oil is used. Fuel oil with a $0.1 \%$ sulfur content is burned during unusually cold weather or if the natural gas supply to Mound is interrupted. Approximately 13,888 liters (3669 gallons) of fuel oil were burned during 1993.
As described in Chapter 3, Mound has four air permits from the Ohio EPA. A number of other sources, such as the powerhouse, are registered with the Regional Air Pollution Control Agency (RAPCA).

Nonradiological airborne emissions for 1993 are summarized in Table 5-1.

Table 5-1. Nonradiological Airborne Effluent Data for 1993

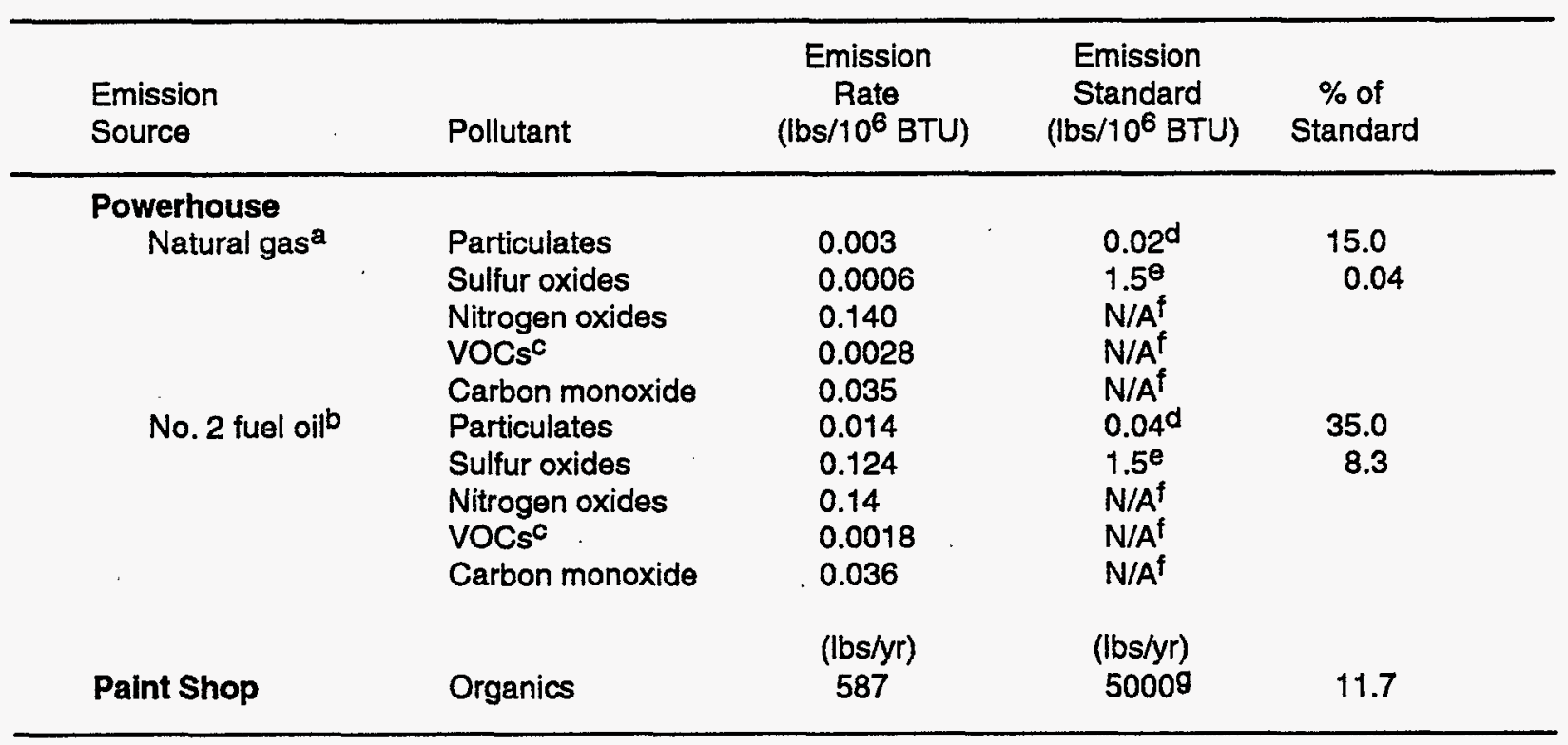

aEmission factors from AP-42, Small Industrial Boilers (EPA, 1985). Assumed fuel heat content $=1000$ BTU/At ${ }^{3}$.

${ }^{b}$ No. 2 fuel oil nominal sulfur content $=0.12 \%$. Assumed fuel heat content $=139.0 \mathrm{kBTU} / \mathrm{gal}$.

cVOCs = Volatile organic compounds (excluding methane).

DOhio EPA Regulation 3745-17-10.

Ohio EPA Regulation 3745-18-63.

$f_{N} / A=$ not applicable. Boiler size is below regulatory threshold.

gCondition of permit. 
Mound evaluates particulate concentrations at 7 onsite and 15 offsite locations. High-volume particulate air samples are collected weekly by flowing air through a $200-\mathrm{mm}$ diameter fiber glass filter. The system operates at about $1.3 \times 10^{6}$ $\mathrm{cm}^{3} / \mathrm{min}$ which represents a sample volume of
$13,000 \mathrm{~m}^{3}$ of air per week. By weighing the filter paper before and after use, it is possible to determine the mass of particulates retaineu by the filter. The mass loading and known air volume can then be used to generate concentration values ( Table 52).

Table 5-2. 1993 Particulate Concentrations

\begin{tabular}{|c|c|c|c|c|c|}
\hline \multirow{2}{*}{$\begin{array}{l}\text { Sampling } \\
\text { Location }^{\mathrm{a}}\end{array}$} & \multirow{2}{*}{$\begin{array}{l}\text { Number } \\
\text { of } \\
\text { Samples }\end{array}$} & \multicolumn{2}{|c|}{$\begin{array}{l}\text { Particulate Concentration } \\
\qquad\left(\mu \mathrm{g} / \mathrm{m}^{3}\right)\end{array}$} & & \multirow{2}{*}{$\begin{array}{l}\text { Arithmetic } \\
\text { Average } \\
\left(\mu g^{2} \mathrm{~m}^{3}\right)\end{array}$} \\
\hline & & Minimum & Maximum & & \\
\hline \multicolumn{6}{|l|}{ Offsite } \\
\hline 101 & 51 & 23 & 88 & & $46 \pm 4$ \\
\hline 102 & 52 & 16 & 59 & & $31 \pm 3$ \\
\hline 103 & 50 & 11 & 44 & & $25 \pm 2$ \\
\hline 104 & 52 & 17 & 54 & & $31 \pm 2$ \\
\hline 105 & 51 & 15 & 188 & & $42 \pm 10$ \\
\hline 108 & 52 & 17 & 68 & & $42 \pm 3$ \\
\hline 110 & 52 & 15 & 49 & & $27 \pm 2$ \\
\hline 111 & 52 & 17 & 76 & & $36 \pm 3$ \\
\hline 112 & 52 & 14 & 47 & & $27 \pm 2$ \\
\hline 115 & 52 & 15 & 90 & & $32 \pm 4$ \\
\hline 118 & 52 & 13 & 46 & & $26 \pm 2$ \\
\hline $119^{d}$ & 46 & 11. & 44 & & $25 \pm 2$ \\
\hline 122 & 52 & 12 & 58 & & $29 \pm 3$ \\
\hline 123 & 52 & 17 & 55 & & $34 \pm 2$ \\
\hline 124 & 52 & 15 & 59 & & $31 \pm 3$ \\
\hline \multicolumn{6}{|l|}{ Onsite } \\
\hline 211 & 49 & 11 & 177 & & $39 \pm 6$ \\
\hline 212 & 48 & 5 & 127 & - & $37 \pm 6$ \\
\hline $213 \mathrm{~A}$ & 49 & 10 & 65 & & $36 \pm 3$ \\
\hline $214 R$ & 48 & 13 & 70 & & $34 \pm 3$ \\
\hline $215 \therefore$ & 49 & 10 & 56 & . & $27 \pm 3$ \\
\hline 216 . & 49 & 16 & 66 & $\because$ & $35 \pm 3$ \\
\hline 217 & 49 & 16 & 71 & . & $35 \pm 4$ \\
\hline
\end{tabular}

a Sampling locations shown in Figures 4-10 and 4-11 for onsite and offsite sampling stations, respectively.

b Ohio Ambient Air Quality Standard is $50 \mu \mathrm{g} / \mathrm{m}^{3}$ (annual arithmetic mean).

c Values are weekly averages.

Error limits are estimates of the standard error of the estimated means at the $95 \%$ confidence level.

d Background location (approx. $28 \mathrm{mi}$. NW of Mound). 


\section{Chapter 5}

As the data in Tables 5-1 and 5-2 demonstrate, nonradioactive air emissions from Mound in 1993 did not significantly affect ambient air quality. All regulated releases were below permit limits, and comparisons of particulate concentrations measured onsite versus offsite suggest little or no influence by Mound. Particulate measurements for a few sampling locations exhibited periodic increases due to construction activities. These elevated air loadings were of short duration and did not significantly affect average values for 1993.

\subsection{Water Monitoring Program}

Mound releases wastewater to offsite surface waters via three discharge systems. In 1993, Mound discharged an average of 2.78 million liters ( 0.73 million gallons) of water per day to the Great Miami River. U.S. Geological Survey data indicate that the 1993 flow rate in the River averaged 2470 million gallons per day (MGD), with a minimum and maximum flow rate of 65 MGD and 16,215MGD, respectively. The average magnitude of the river flow rate is significantly greater than that of Mound's effluents. Therefore, releases from Mound can be expected to have minimal impact on river water quality.

Mound's discharges are regulated by a National Pollutant Discharge Elimination System(NPDES) permit. Mound's permit was renewed in October of 1992; it will remain valid through March of 1997.

\section{NPDES Monitoring Requirements}

Mound's NPDES permit requires scheduled collection and analysis of Plant effluents at four onsite locations (Outfalls 5601, 5602, 5603, and 5002). Flow-weighted effluent limitations are further imposed for the combined discharges from Outfalls 5601 and 5602 (calculated Outfall 5001). Additional sampling requirements are required for one offsite outfall (5604) and three Great Miami River locations (5801, 5901, and 5902).
These locations are shown in Figure 5-1. The sampling requirements established for each outfall are listed in Table 5-3.

Outfall 5601. Outfall 5601 contains the effluent from Mound's sanitary sewage treatment plant. Flow-proportional, 24-hour composite samples and periodic grab samples are collected at this outfall. NPDES permit requirements for this location focus on bacteria and heavy metals. Though not a condition of the permit, Mound also analyzes the effluent quarterly for total toxic organics (TTOs).

Outfall 5602. Outfall 5602 includes storm water runoff, single-pass cooling water, cooling tower blowdown, zeolite softener backwash, and effluent from the radioactive waste disposal facilitiy. Flowproportional, 24-hour composite samples and periodic grab samples are collected at this outfall. NPDES permit requirements for this location are more limited: chemical oxygen demand, suspended solids, and oil and grease content are of concern. Though not a condition of the permit, Mound also analyzes the effluent quarterly for total toxic organics (TTOs).

Outfall 5603. Outfall 5603 is associated with an electroplating facility operated onsite. Timeproportional composite samples and periodic grab samples are collected at this outfall. Because the effluent is associated with a plating shop, the parameters of concern are heavy metals and cyanide. The NPDES permit also requires quarterly TTO sampling.

Outfall 5002. Discharge 5002 contains softener backwash and most of the Plant's storm water runoff. Flow-proportional, 24-hour composite samples and periodic grab samples are collected at this outfall. NPDES permit requirements for this location focus on bacteria and heavy metals. Though not a condition of the permit, Mound also analyzes the effluent quarterly for total toxic organics (TTOs). 
Figure 5-1. NPDES Sampling Locations

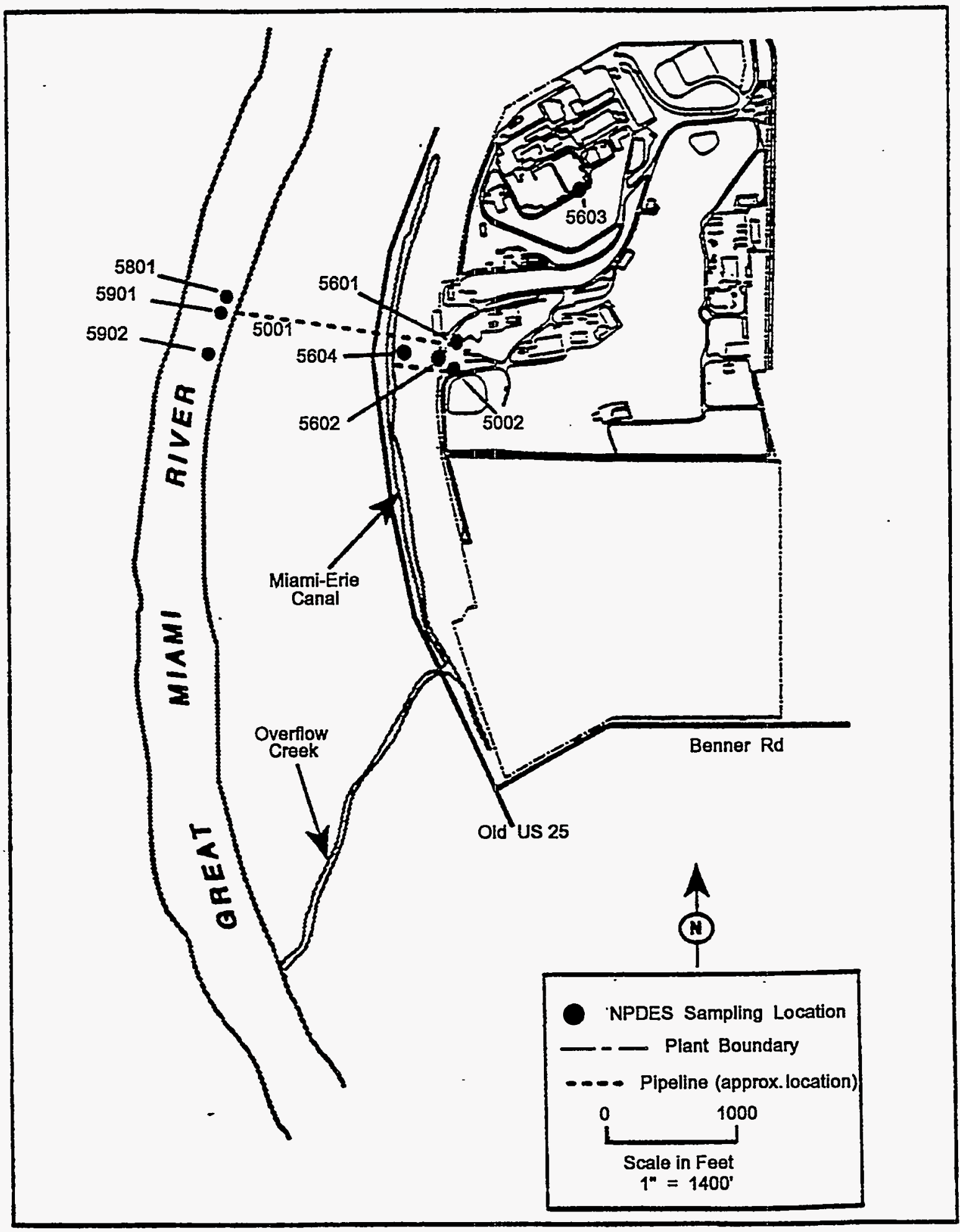


Table 5-3. National Pollutant Discharge Elimination System Data for 1993

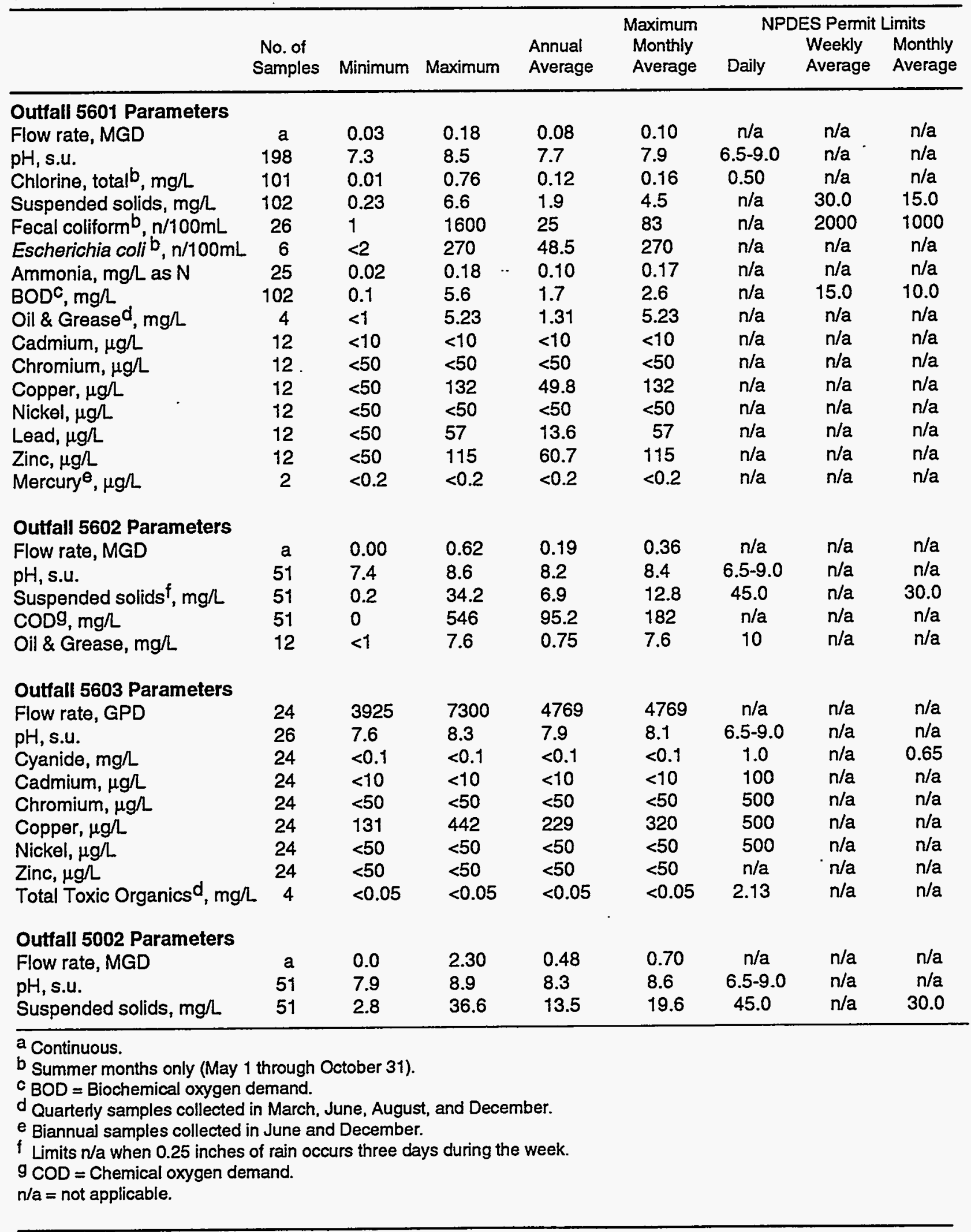


Table 5-3 (continued)

\begin{tabular}{|c|c|c|c|c|c|c|c|}
\hline & $\begin{array}{l}\text { No. of } \\
\text { Samples }\end{array}$ & Minimum & Maximum & $\begin{array}{l}\text { Annual } \\
\text { Average }\end{array}$ & $\begin{array}{l}\text { Maximum } \\
\text { Monthly } \\
\text { Average }\end{array}$ & $\begin{array}{l}\text { NPDES } \\
\text { Daily }\end{array}$ & $\begin{array}{l}\text { it Limits } \\
\text { Monthly } \\
\text { Average }\end{array}$ \\
\hline \multicolumn{8}{|l|}{ Outfall 5001 Parameters } \\
\hline Flow rate, MGD & a & 0.04 & 0.71 & 0.25 & 0.42 & $n / a$ & $\mathrm{n} / \mathrm{a}$ \\
\hline $\mathrm{pH}$, s.u. & 27 & 7.7 & 8.4 & 8.1 & 8.4 & $6.5-9.0$ & $n / a$ \\
\hline Residual Chlorineb ${ }^{b}, \mathrm{mg} / \mathrm{L}$ & 26 & 0.01 & 0.15 & 0.04 & 0.06 & $0.038^{h}$ & $n / a$ \\
\hline Cyanide, mg/L & 12 & $<0.01$ & $<0.01$ & $<0.01$ & $<0.01$ & 0.083 & 0.023 \\
\hline Pentachlorophenol, $\mu \mathrm{g} / \mathrm{L}$ & 12 & $<4$ & $<4$ & $<4$ & $<4$ & $n / a$ & $\mathrm{n} / \mathrm{a}$ \\
\hline \multicolumn{8}{|l|}{ Bis(2-ethylhexyl) } \\
\hline phthalate, $\mu \mathrm{g} / \mathrm{L}$ & 12 & $<4$ & 232 & 26 & 232 & $n / a$ & $\mathrm{n} / \mathrm{a}$ \\
\hline Cadmium, $\mu g / L$ & 51 & $<10$ & 1.3 & $1: 9$ & $<10$ & 43 & $\mathrm{n} / \mathrm{a}$ \\
\hline Chromium, $\mu \mathrm{g} / \mathrm{L}$ & 51 & $<50$ & $<50$ & $<50$ & $<50$ & 878 & 546 \\
\hline Copper, $\mu g \Omega$ & 51 & $<50$ & 106 & 44.5 & 93 & 120 & $\mathrm{n} / \mathrm{a}$ \\
\hline Nickel, $\mu g / L$ & 51 & $<50$ & 62 & $<50$ & $<50$ & 1261 & 760 \\
\hline Lead, $\mu \mathrm{g} \Omega$ & 51 & $<50$ & 135 & $<50$ & 79 & 305 & 191 \\
\hline \multirow{2}{*}{\multicolumn{8}{|c|}{ Ceriodaphnia dubia }} \\
\hline & & & & & & & \\
\hline acute, TUi & 8 & 0 & 1.7 & 0.6 & 1.7 & $n / a$ & $\mathrm{n} / \mathrm{a}$ \\
\hline chronic, TU & 4 & 0 & 1.3 & 1.3 & 1.3 & $n / a$ & $\mathrm{n} / \mathrm{a}$ \\
\hline \multicolumn{8}{|l|}{ Pimephales promelas } \\
\hline acute, TU & 8 & 0 & 0.4 & $<0.1$ & 0.4 & $n / a$ & $\mathrm{n} / \mathrm{a}$ \\
\hline chronic, TU & 4 & 0 & 0 & 0 & 0 & $\mathrm{n} / \mathrm{a}$ & n/a \\
\hline \multicolumn{8}{|l|}{ Outfall 5604 Parameters } \\
\hline Flow rate, MGD & \multirow{2}{*}{\multicolumn{7}{|c|}{ Outfall not used during 1993.}} \\
\hline $\mathrm{pH}, \mathrm{s.u}$. & & & & & & & \\
\hline \multirow{2}{*}{\multicolumn{8}{|c|}{$\begin{array}{l}\text { Outfall 5801 Parameters } \\
\text { \% affected: } \\
\text { Ceriodaphnia dubia. }\end{array}$}} \\
\hline & & & & & & & \\
\hline 48-hour acute, TUi & 12 & 0 & 10 & 2.9 & 10.0 & $n / a$ & $\mathrm{n} / \mathrm{a}$ \\
\hline \multicolumn{8}{|l|}{ Pimephales promelas } \\
\hline 96-hour acute, TU & 12 & 0 & 17.5 & 2.5 & 17.5 & $\mathrm{n} / \mathrm{a}$ & $\mathrm{n} / \mathrm{a}$ \\
\hline
\end{tabular}

a Continuous.

b Summer months only (May 1 through October 31).

c $\mathrm{BOD}=$ Biochemical oxygen demand.

d G: rarteriy samples collected in March, June, August, and December.

e Biannual samples collected in June and December.

$f$ Limits $n / a$ when 0.25 inches of rain occurs three days during the week.

$\mathrm{g} \mathrm{COD}=$ Chemical oxygen demand.

h Limit not imposed until October 1, 1995.

i TU = toxicity units.

$\mathrm{n} / \mathrm{a}=$ not applicable. 
Table 5-3 (continued)

\begin{tabular}{|c|c|c|c|c|c|c|c|}
\hline & $\begin{array}{l}\text { No. of } \\
\text { Samples }\end{array}$ & Minimum & Maximum & $\begin{array}{l}\text { Annual } \\
\text { Average }\end{array}$ & $\begin{array}{l}\text { Maximum } \\
\text { Monthly } \\
\text { Average }\end{array}$ & $\begin{array}{l}\text { NPD } \\
\text { Daily }\end{array}$ & $\begin{array}{l}\text { it Limits } \\
\text { Monthly } \\
\text { Average }\end{array}$ \\
\hline \multicolumn{8}{|c|}{$\begin{array}{l}\text { Outfall } 5901 \text { Parameters } \\
\text { \% affected: } \\
\text { Ceriodaphnia dubia }\end{array}$} \\
\hline $\begin{array}{l}\text { 48-hour acute, TUi } \\
\text { Pimephales promelas }\end{array}$ & 12 & 0 & 100 & 19.2 & 100 & $n / a$ & $n / a$ \\
\hline 96-hour acute, TU & 12 & 0 & 30 & 2.9 & 30 & $\mathrm{n} / \mathrm{a}$ & $n / a$ \\
\hline \multicolumn{8}{|c|}{$\begin{array}{l}\text { Outfall } 5902 \text { Parameters } \\
\% \text { affected: }\end{array}$} \\
\hline $\begin{array}{l}\text { 7-day chronic, TUi } \\
\text { Pimephales promelas }\end{array}$ & 4 & 0 & 10 & 5.0 & 10.0 & $\mathrm{n} / \mathrm{a}$ & $n / a$ \\
\hline 7-day chronic, TU & 4 & 5 & 22.5 & 9.4 & 22.5 & $n / a$ & $n / a$ \\
\hline
\end{tabular}

a Continuous.

b Summer months only (May 1 through October 31).

c BOD = Biochemical oxygen demand.

d Quarterly samples collected in March, June, August, and December.

e Biannual samples collected in June and December.

$t$ Limits $n / a$ when 0.25 inches of rain occurs three days during the week.

$9 \mathrm{COD}=$ Chemical oxygen demand.

$h$ Limit not imposed until October 1, 1995.

$\mathrm{i} \mathrm{TU}=$ toxicity units.

$\mathrm{n} / \mathrm{a}=$ not applicable.

Calculated Outfall 5001. Outfall 5001 represents the combined effluents of 5601 and 5602 . These discharges are combined and released to the Great Miami River via a closed pipe. Since sampling the pipe is not practical, Mound's NPDES permit imposes additional limits for this outfall based on flow-weighted calculations. The concentrations of materials present in Outfalls 5601 and 5602 are used, along with their respective flow rates, to estimate concentrations in the effluent discharged through the pipe. The limits associated with Outfall 5001 are also listed in Table 5-3.
Outfall 5604. Outfall 5604 is an abandoned well located west of the Plant site. In the past Mound has purged the well, known as Miamisburg Abandoned Well No. 2, to lower tritium concentrations. The purged water was then directed through a closed pipe to the Great Miami River. When this activity is performed, Mound's NPDES permit requires that the flow rate and $\mathrm{pH}$ be recorded. The well was most recently pumped in 1991. It was pumped for six days; a total volume of 3.51 million gallons was discharged at an average $\mathrm{pH}$ of 7.2 . 


\section{Nonradiological Environmental Program Information}

Sampling Locations 5801, 5901, and 5902. A new requirement of Mound's NPDES permit involves toxicity testing of water samples taken from the Great Miami River. The permit specifies that monthly (for acute toxicity testing) and quarterly (for chronic toxicity testing) samples be collected from specific river locations and plant effluents (Table 5-3 and Figure 5-1). The water samples are then evaluated using water fleas (Ceriodaphnia dubia) and fathead minnows (Pimephales promelas).

\section{Results}

A total of 1574 samples were analyzed forNPDES parameters in 1993. Key results are summarized in Tables 5-3 and 5-4. Analytical procedures were consistent with the methods specified in regulations of the Clean Water Act, 40 CFR 136. Sampling and analytical services were provided by Mound's Environmental Monitoring and Bioassay Labs and by outside contractors. All such procedures were required to meet Mound standards for quality assurance and quality control.

One NPDES exceedance or "upset" did occur in 1993. On August 5, 1993, Mound recorded a chlorine concentration of $0.76 \mathrm{mg} / \mathrm{L}$ for Outfall 5601 ; the daily limit for chlorine at that location is $0.5 \mathrm{mg} / \mathrm{L}$. The upset was reported to the Ohio EPA within hours of discovery. The problem was traced to a faulty solenoid valve which was promptly replaced.

A review of Mound's NPDES performance over the past five years is shown in Figure 5-2. As seen in the Figure, Mound recorded a total of eight NPDES upsets between 1989 and 1993. During that time period, 5254 NPDES samples were collected.

Figure 5-2. NPDES Sample Profile for the Five-Year Period 1989 - 1993

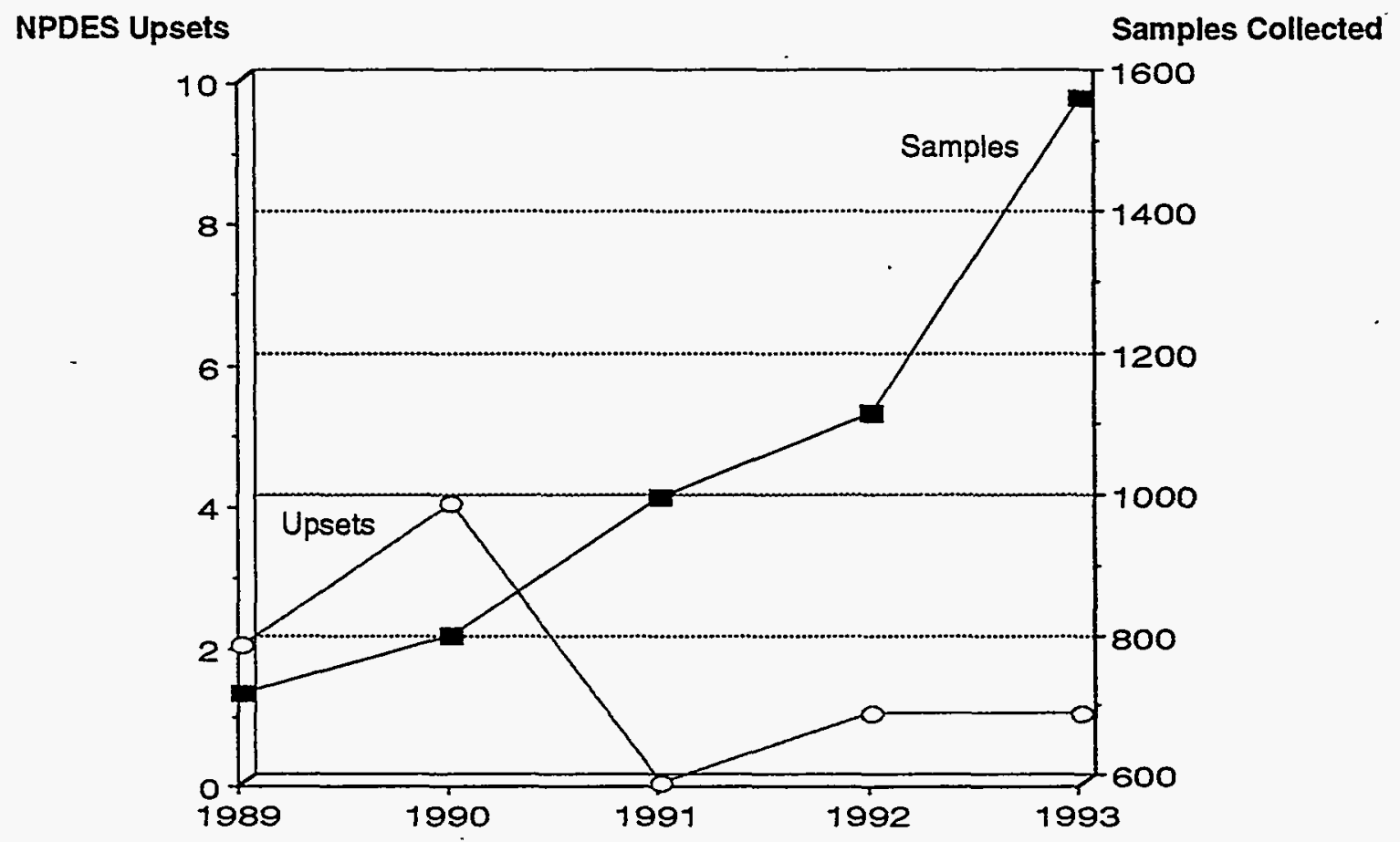


Table 5-4. Summary of Organic Compounds Detected in Mound Effluents in 1993

\begin{tabular}{|c|c|c|c|c|c|c|}
\hline \multirow[b]{2}{*}{ Outfall ${ }^{\star}$} & \multirow[b]{2}{*}{ Parameter } & \multicolumn{5}{|c|}{ Concentration, $\mu \mathrm{g} / \mathrm{L}$} \\
\hline & & $\begin{array}{c}\text { 1st } \\
\text { Quarter }\end{array}$ & $\begin{array}{c}\text { 2nd } \\
\text { Quarter }\end{array}$ & $\begin{array}{c}\text { 3rd } \\
\text { Quarter }\end{array}$ & $\begin{array}{c}\text { 4th } \\
\text { Quarter }\end{array}$ & MDLa \\
\hline \multirow[t]{4}{*}{5601} & Chloroform & $N D^{b}$ & 2.2 & ND & ND & 1 \\
\hline & Bis(2-ethylhexyl)phthalate & ND & ND & ND & $5^{c}$ & 4 \\
\hline & Napthalene & ND & ND & 39 & ND & 4 \\
\hline & Trichloroethene & ND & ND & ND & 1.6 & 1 \\
\hline \multirow[t]{3}{*}{5602} & Bromoform & 2.1 & 1.0 & ND & ND & 1 \\
\hline & Dibromochloromethane & 1.9 & ND & ND & ND & 1 \\
\hline & Bis(2-ethylhexyl)phthalate & ND & 7.0 & ND & ND & 4 \\
\hline \multirow[t]{6}{*}{5603} & Tetrachloroethene & ND & ND & ND & 2.7 & 1 \\
\hline & Bromoform & 5.0 & 2.0 & 5.8 & 1.3 & 1 \\
\hline & Dibromochloromethane & 5.1 & 2.3 & 3.6 & 1.7 & 1 \\
\hline & Bis(2-ethylhexyl)phthalate & ND & ND & ND & 9.0 & 4 \\
\hline & Bromodichloromethane & 2.1 & 1.0 & ND & ND & 1 \\
\hline & Trichloroethene & ND & ND & ND & 5.9 & 1 \\
\hline 5002 & Bis(2-ethylhexyl)phthalate & 5.0 & ND & 13 & ND & 4 \\
\hline
\end{tabular}

- Outfall locations shown on Figure 5-1.

a $\mathrm{MDL}=$ Method detection limit.

b ND = None detected.

c This compound was present in the extraction blank at a concentration of $5 \mu \mathrm{g} / \mathrm{L}$. 


\section{Nonradiological Environmental Program Information}

\subsection{Submissions Under SARA Title III}

Title III of the Superfund Amendments and Reauthorization Act (SARA) addresses the emergency planning and community right-toknow responsibilites of facilities handling hazardous substances. Sections 311 and 312 of Title III specify reporting requirements for the use and/or storage of "extremely hazardous" and "hazardous" substances. For facilities subject to Sections 311 and 312 , chemical usage, storage, and location information must be submitted to regional emergency response agencies by March 1 of each year. For 1993, Mound reported using and/or storing three extremely hazardous substances and 8 hazardous substances. This information, along with site maps showing usage and storage locations, was submitted to the State Emergency Response Commission, the Miami Valley Regional Planning Commission, and the City of Miamisburg Fire Department. The 11 substances handled by Mound are listed in Table 5-5.

\section{Table 5-5. 1993 Emergency and Hazardous Chemical Data for Mound}

\section{Hazardous Substances}

Diesel fuel

No. 2 fuel oil

Gasoline, unleaded
Nitrogen, liquid

Helium, liquid

Argon, liquid
Ethylene glycol

Calcium chloride

\section{Extremely Hazardous Substances}

Chlorine

Sulfuric acid

Nitric acid

Section 313 of Title III specifies reporting requirements associated with the release of toxic chemicals. Each year Mound files a Section 313 report, Form R, for methylene chloride. (Methylene chloride usage in recent years has declined; however, the reporting requirements use 1988 as a baseline.) Based on a review of chemical release data for 1993, no additional chemicals in use at Mound warrant Section 313 submissions.

\subsection{Environmental Occurrences}

Under CERCLA and the Clean Water Act, reportable quantity ( $R Q$ ) levels have been established for designated hazardous substances. If a spill or other inadvertent release to the environment exceeds the $R Q$, immediate notification of the appropriate federal agencies (e.g., National Response Center, EPA, or Coast Guard) is required. No such releases occurred at Mound during 1993. 


\subsection{GROUNDWATER MONITORING PROGRAM}

The Mound Plant site lies atop the largest of Ohio's sole-source aquifers, the Buried Valley Aquifer (BVA). The City of Miamisburg, and a number of other communities in the area, draw drinking water from the BVA. Mound also relies on the BVA for drinking and process water.

Mound has approximately 200 active groundwater monitoring sites in place onsite and offsite to characterize the impact Plant operations may have on the BVA. These sites consist of three production wells, 126 monitoring wells, 39 piezometers, ten capture pits, nine residential wells, and 12 community wells. The groundwater monitoring program has been developed to meet the SDWA monitoring requirements, RCRA monitoring requirements as applicable or relevant and appropriate requirements (ARARs) for the CERCLA Program, and DOE-mandated practices.

\subsection{Regional Geohydrology}

Beneath the Miami Valley region of southwest Ohio lies the Buried Valley Aquifer (BVA). The BVA was designated a sole-source aquifer by the USEPA in May, 1988. This distinction indicates that the aquifer supplies all of the drinking.water to the communities above it. The approximate area extent of the BVA is shown in Figure 6-1.

Figure 6-1. Location and Extent of the Buried Valley Aquifer

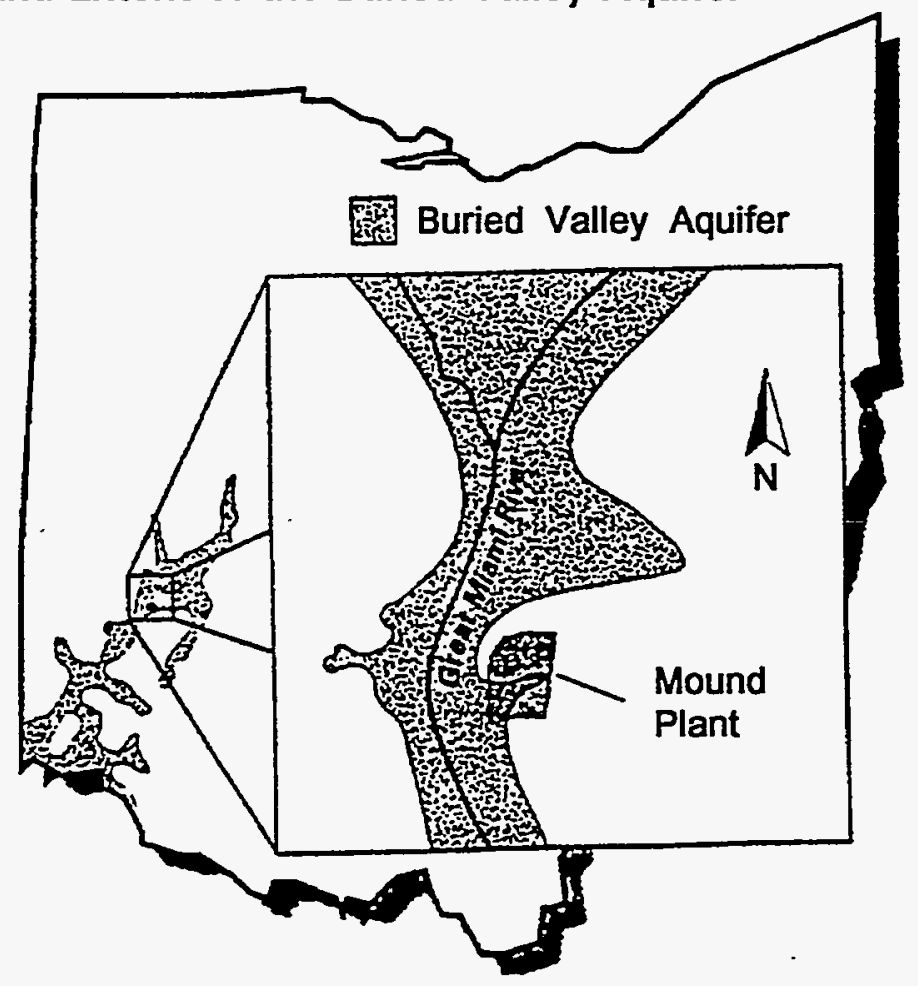


The aquifer has a north-south orientation and reaches a maximum thickness of about $46 \mathrm{~m}$ ( 150 $\mathrm{ft}$ ) near the Great Miami River channel. Groundwater in the area generally flows south, following the downstream course of the River. Recharge by induced stream infiltration occurs, although in this region the aquifer contains extensive layers of clayish till which impede infiltration. The BVA west of the Plant site is estimated to have calculated transmissivity values ranging from 200,000 to 430,000 gallons per day per foot. The transmissivity values are based upon hydraulic characterization data obtained from a May 1993 aquifer pump test (Section 6.2).

The BVA is somewhat overdrawn between the cities of West Carrollton and Dayton. Practices involving relocation of well fields and artificial recharge via infiltration lagoons are in use to reduce the magnitude of the reversal. Currently, there is no evidence that the gradient reversal affects regions south of West Carrollton such as Miamisburg. At Miamisburg, pumping does not influence the natural groundwater gradient except in the immediate vicinity of individual well fields.

\section{Uses of Groundwater in the Vicinity}

There are seven municipal water supplies and numerous industrial users within an $8 \mathrm{~km}(5 \mathrm{mi})$ radius of the Mound Plant. The locations of public and private water supply wells are shown in Figure 6-2 (pages 6-4 and 6-5). The only industrial user within $8 \mathrm{~km}(5 \mathrm{mi})$ downgradient is the O. H. Hutchings Power Generation Station. Industrial groundwater users located north (upgradient) of the site are isolated from Mound by hydraulic barriers.

The City of Springboro is the first downgradient water supply, but it should not be significantly affected by Mound Plant since it is approximately $6.5 \mathrm{~km}$ (4 mi) down-valley of the Plant. The City of Miamisburg owns ten wells in the BVA. At this time only the four wells located on the west side of the Great Miami River are in use. These wells are upgradient and should not be impacted by groundwater contamination from the Mound Plant. All city wells currently in service are separated from the plant by a minimum straight-line distance of $0.8 \mathrm{~km}(0.5 \mathrm{mi})$.

In 1992 a residential well and cistern study (DOE, 1993a) was conducted. A total of 216 residential wells and 14 cisterns were identified within a 2mile radius of the Mound Plant. A representative subset of these wells will be used by Mound's ER Program to assess potential groundwater impacts of plant operations on these water sources.

\subsection{Hydrology at Mound}

As seen in Figure 6-1, the "tongue" of the BVA extends onto the Mound Plant site. Within the limits of the property, the maximum known thickness of the aquifer is about $21 \mathrm{~m}(70 \mathrm{ft})$ at the extreme southwest corner of the site. Present usage of BVA water by Mound ranges from 19 to 32 liters/second ( 300 to 500 gallons per minute). Recharge to the portion of the BVA underlying Mound primarily arises from direct infiltration of river water, precipitation, and leakage from valley walls. These sources of recharge provide sufficient volumes of water to balance Mound's withdrawals.

Groundwater elevations are shown on Figure 6-3 (pages 6-6 and 6-7). Groundwater levels vary from elevations near $700 \mathrm{ft}$ to approximately 800 ft. Onsite groundwater levels increase with increasing ground surface elevations. (Ground surface elevations were shown on Figure 1-6.) The maximum groundwater level beneath the site is 800 feet. This elevation occurs under the main hill which has a maximum ground surface elevation of approximately $880 \mathrm{ft}$. 


\section{Aquifer Pump Test}

An aquifer test was performed from May 14 through June 28 at one of the Mound Plant production wells, Well No. 0071 (also referred to as Well \#1). The test was used to determine the aquifer characteristics in and around Operable Unit 1 . Sixty-two wells and piezometers in the vicinity of OU 1 , both onsite and offsite, were monitored for drawdown during the test. The calculated transmissivity of the surrounding aquifer ranged from 27,500 to $55,200 \mathrm{ft}^{2} /$ day. These values are lower than those calculated for a 1990 aquifer test. In the 1990 test, transmissivities ranged from 37,000 to 83,000 $\mathrm{ft}^{2} /$ day.
Another purpose of the aquifer test was to demonstrate the effectiveness of Well 0071 as a capture well. Selected wells, including Well 0071, were monitored for volatile organic compounds during the test. The single VOC common to all of the wells tested was trichloroethene. The change in trichloroethene concentrations during the pump test is shown in Figure 6-4. The general trend in the concentrations for the non-production wells was characterized by slight increases followed by slight decreases. More information on the test and its results can be found in the OU 1 Remedial Investigation Report (DOE 1994).

\section{Figure 6-4. Trichloroethene Concentrations During the Time Series Sampling}

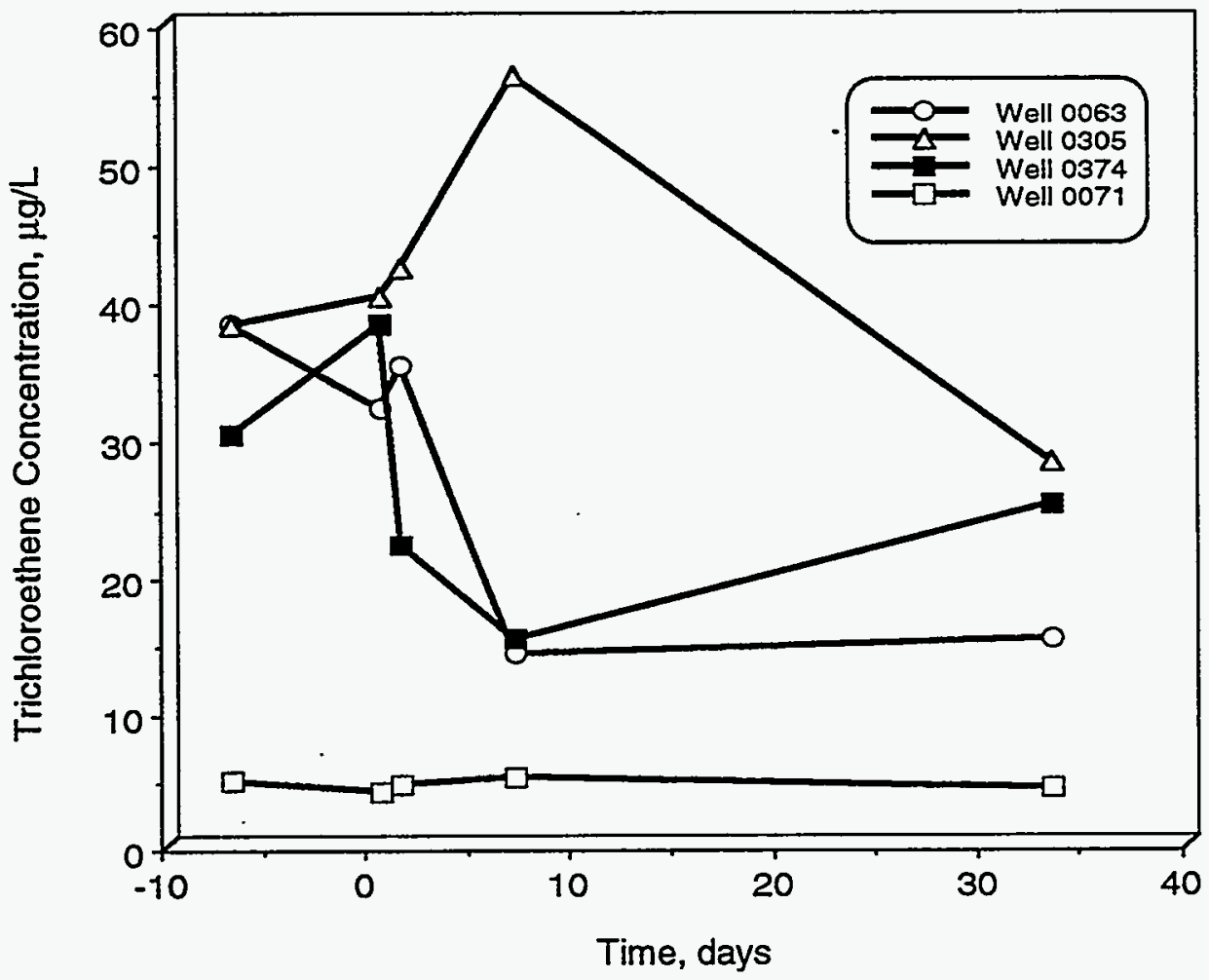


Figure 6-2. Production and Monitoring Well Locations (Plate 1 of 2)

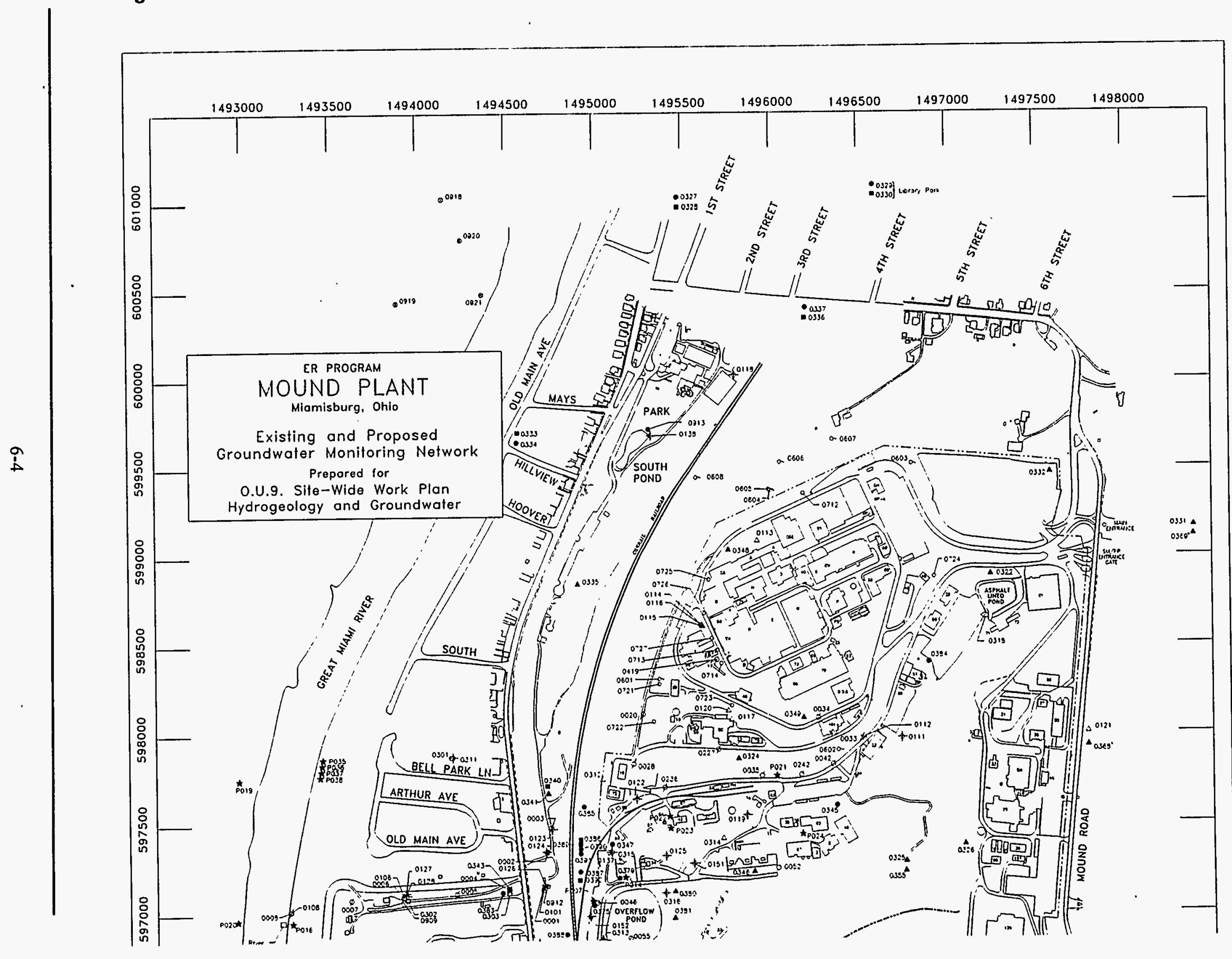


Figure 6-2. Production and Monitoring Well Locations (Plate 2 of 2)

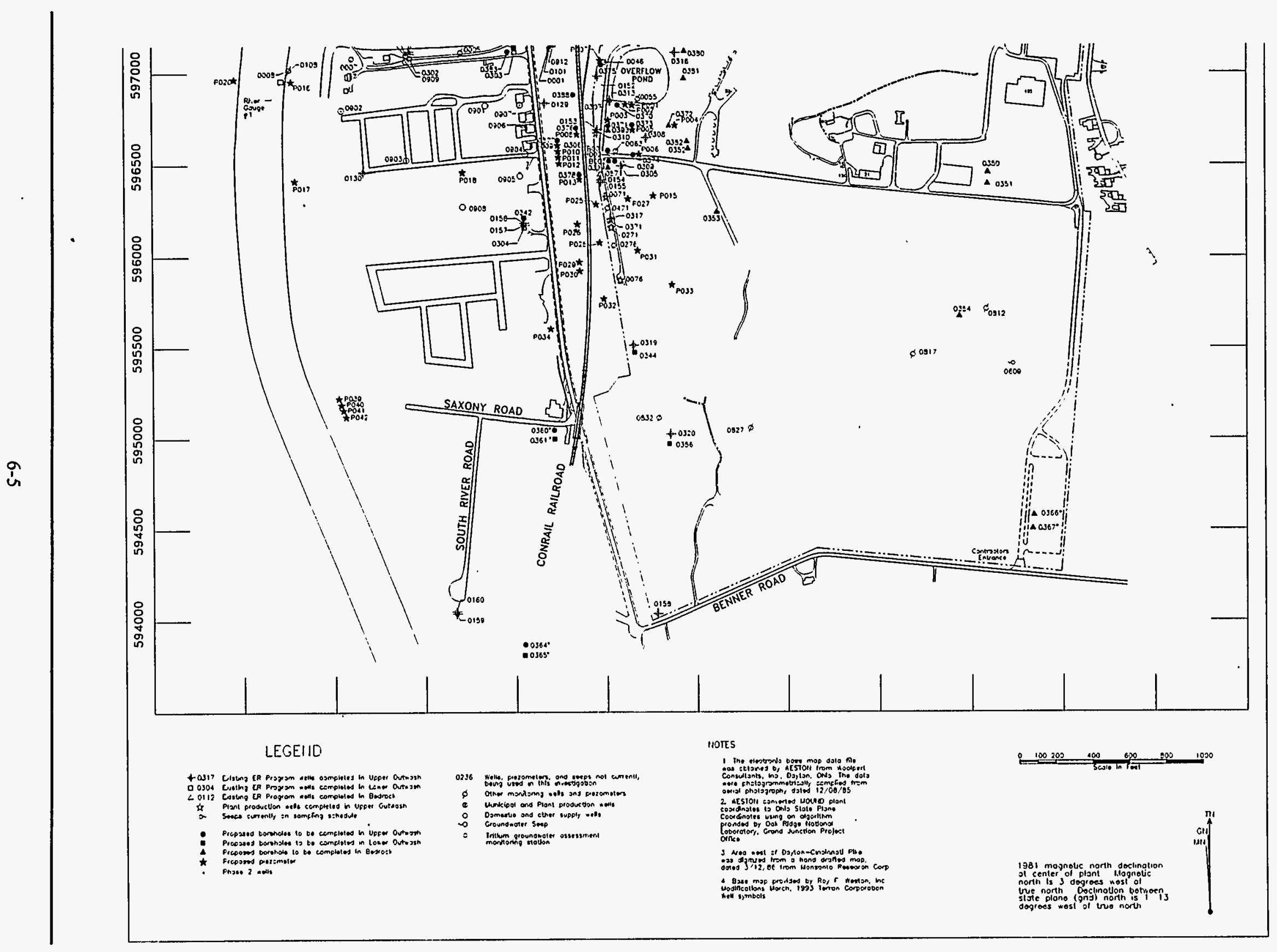




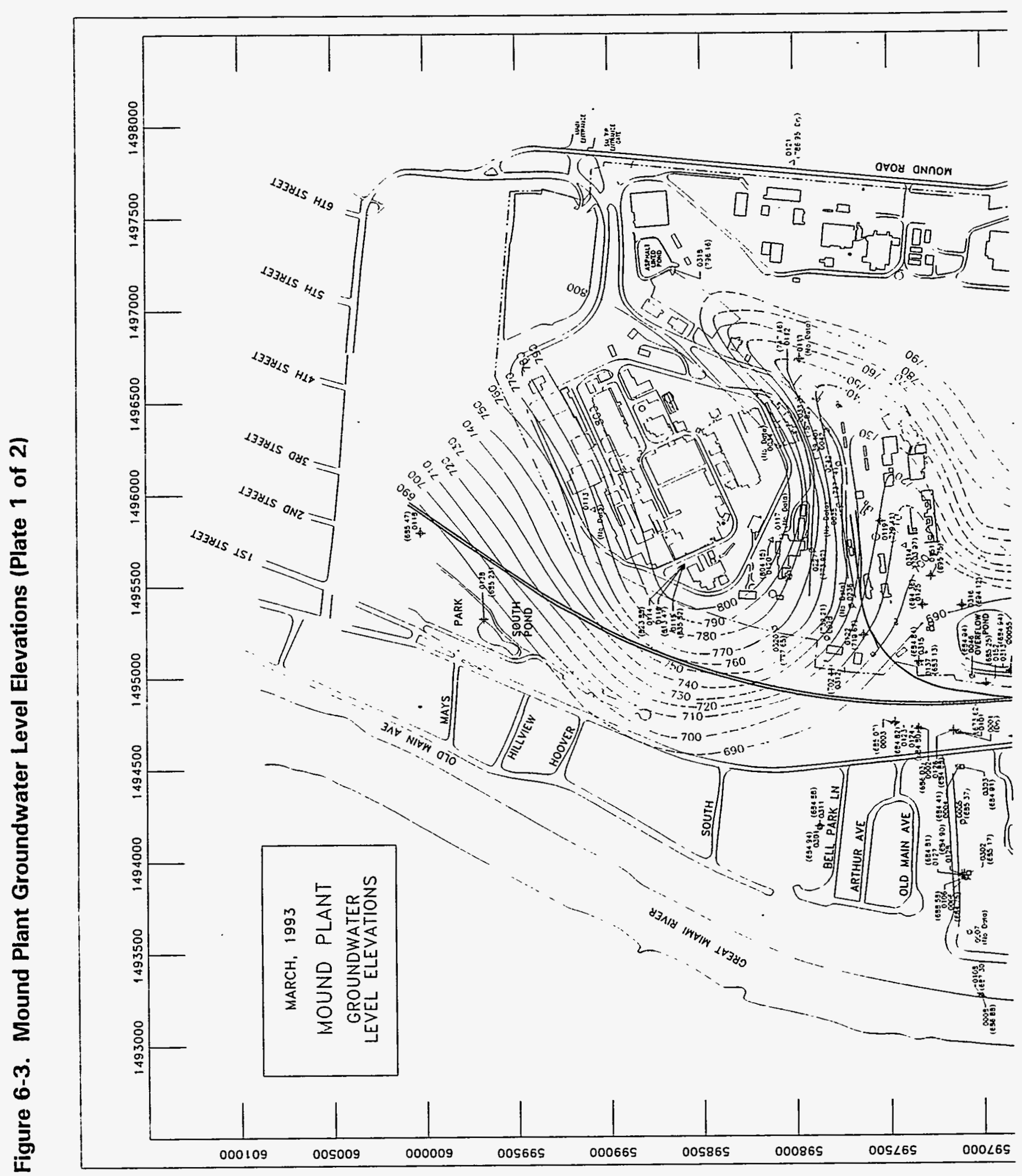




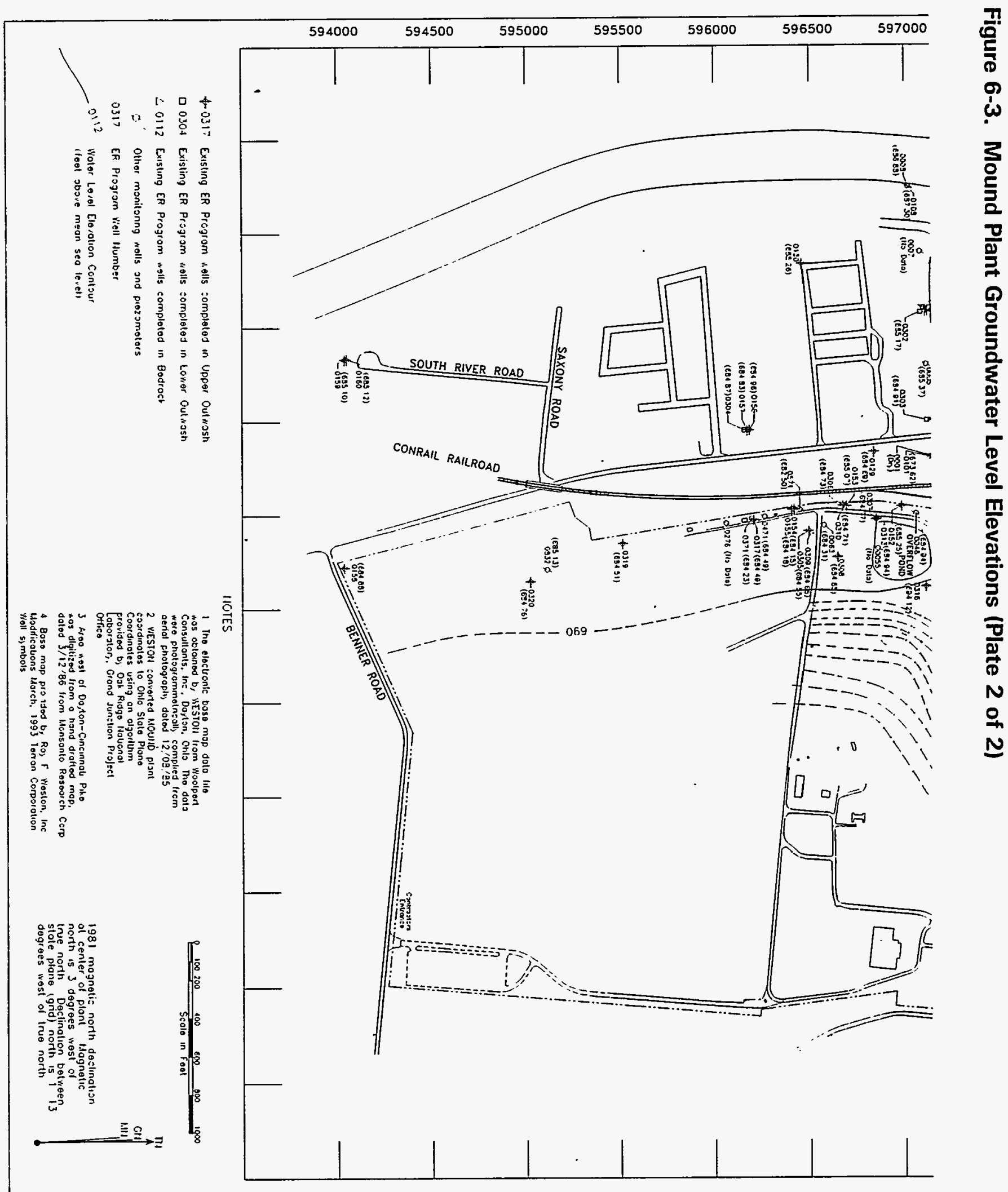


Bedrock permeability. As a result of the dramatic changes in elevations associated with the Plant's topography, the Site has a variety of groundwater regimes. Virtually impermeable bedrock underlies all but the first few feet of the hilltop and hillside areas at Mound. Although the rock itself is impermeable, small quantities of groundwater seep through joints and cracks. The upper $6 \mathrm{~m}$ (20 $\mathrm{ft}$ ) of bedrock, where chemical weathering leads to enlargement of the cracks, is the most permeable. Permeability of the upper $6 \mathrm{~m}(20 \mathrm{ft})$ of bedrock is estimated to range from 40 to $400 \mathrm{~L} / \mathrm{day} / \mathrm{m}^{2}$ (1 to $10 \mathrm{gal} /$ day $\left./ \mathrm{ft}^{2}\right)$. Below this depth, bedrock permeability generally ranges from 0 to $8 \mathrm{~L} /$ day/ $\mathrm{m}^{2}$ (0 to $0.2 \mathrm{gal} /$ day $\left./ \mathrm{ft}^{2}\right)$.

Glacial till and outwash permeability. Hydraulic properties of the glacial tills that form a veneer over the site vary depending on the proportions of fine- and course-grained material at a given location. Values of permeability normally range from 0.0041 to $0.041 \mathrm{~L} /$ day $/ \mathrm{m}^{2}(0.0001$ to 0.001 $\mathrm{gal} /$ day $\left./ \mathrm{ft}^{2}\right)$, although values up to $2.8 \mathrm{~L} /$ day $/ \mathrm{m}^{2}$ $\left(0.007 \mathrm{gal} /\right.$ day $\left.\mathrm{ft}^{2}\right)$ have been measured in upper weathered zones. Below the glacial till in the lower valley is a zone of glacial outwash composed of sand and gravel. The permeability of this zone is estimated to range from 40,700 to $81,000 \mathrm{~L} /$ day $/ \mathrm{m}^{2}\left(1,000\right.$ to $2,000 \mathrm{gal} /$ day $\left.\mathrm{ft}^{2}\right)$.

\section{Seeps}

A key issue for groundwater protection at Mound is the seepage of contaminated water to the surface of the Main Hill. At points along the Plant's north hillside, bedrock is exposed and seep lines exist. A generalized cutaway depicting this phenomenon is shown in Figure 6-5. Numerous samples have been collected from the seeps and analyzed for tritium and volatile organic compounds. Results for 1993 are discussed in Section 6.4 .

\section{Figure 6-5. Geologic Cutaway of the Mound Plant}

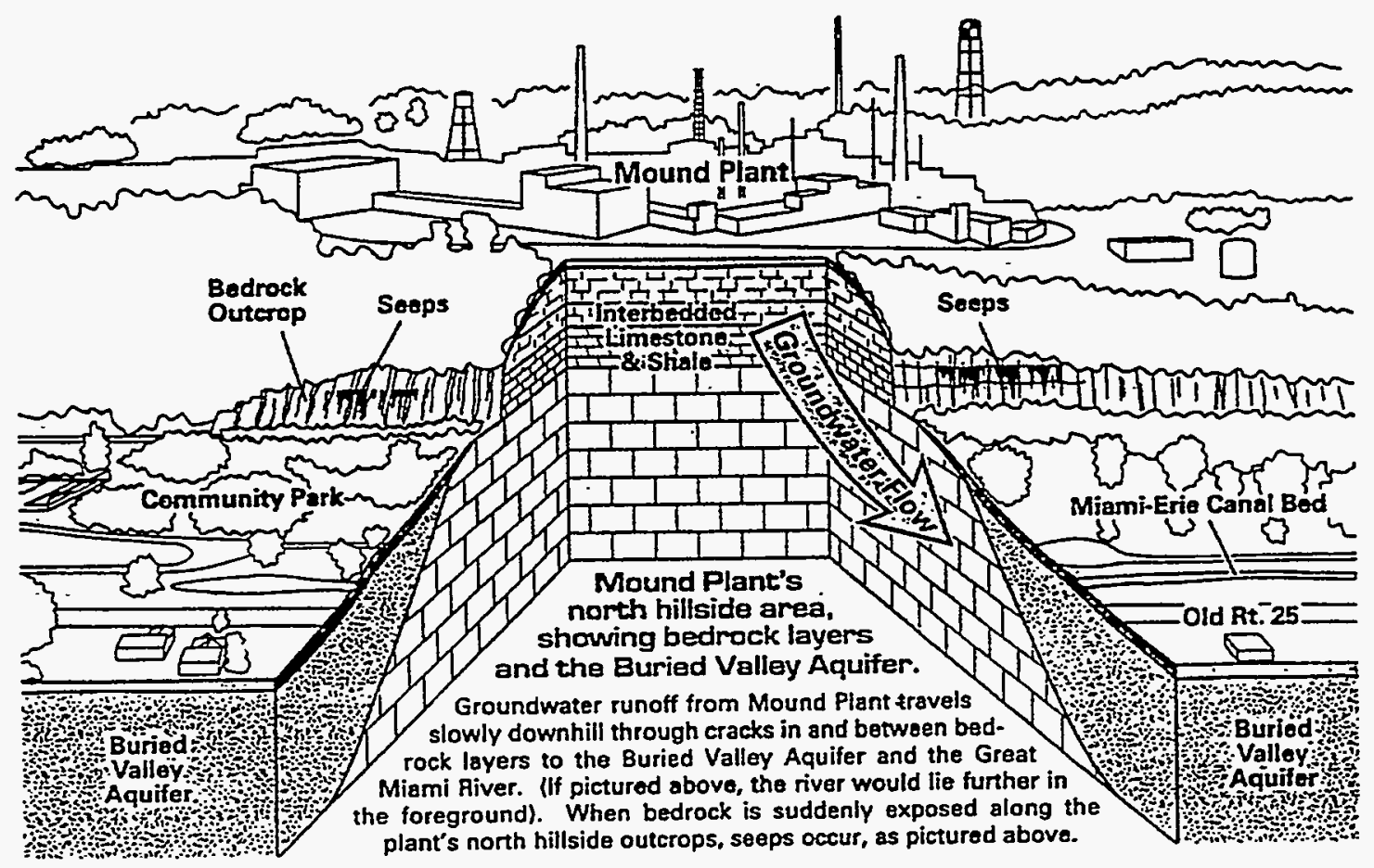




\section{Surface Water Features}

There are no perennial streams on the Plant site. A natural drainage area exists in the deep valley separating the two main hills, but water in this area generally has a short residence time. The basin is relatively small and the slopes are relatively steep. Therefore, runoff through site drainage features is rapid.

\subsection{Offsite Groundwater Monitoring Program}

The offsite groundwater monitoring program at Mound consists of routine collection of samples from production wells, private wells, regional drinking water supplies, and BVA monitoring wells. Samples are collected and analyzed primarily for radionuclides and volatile organic compounds (VOCs). Data from the groundwater analyses performed in 1993 are presented below. (Validated data from newly-installed OU 9 wells were not available at the time this report was published.) Sampling and analytical procedures used to generate these results are documented in Mound's Environmental Monitoring Plan (1994) and Mound's Groundwater Protection Management Program Plan (DOE 1993b).

\section{Tritium in Production and Private Wells}

Private wells immediately downgradient of the Plant have tritium concentrations that are above background. "Background" is established each year by collecting well water from a location unaffected by Plant operations. Those samples are collected from a well $38 \mathrm{~km}$ (22 mi) southeast of Mound. In 1993, tritium concentrations measured at that location were less than or equal to the reagent blanks.

Because tritium is known to have migrated from the Site, downgradient wells are closely monitored for tritium. Sampling results for 1993 are shown in Table 6-1. As seen in the table, the maximum tritium concentration observed was approximately $6.5 \mathrm{nCi} / \mathrm{L}$. This value represents $32.5 \%$ of the EPA's drinking water standard of $20 \mathrm{nCi} / \mathrm{L}$. Average tritium concentrations, however, ranged from $0.24 \mathrm{nCi} / \mathrm{L}$ to $3.6 \mathrm{nCi} / \mathrm{L}$, or $1.2 \%$ and $18 \%$ of the drinking water standard, respectively.

Table 6-1. Tritium Concentrations in Offsite Production and Private Wells in 1993

\begin{tabular}{ccccccc}
\hline $\begin{array}{c}\text { Well } \\
\text { I.D.* }\end{array}$ & $\begin{array}{c}\text { Historic } \\
\text { Designation }\end{array}$ & $\begin{array}{c}\text { Number } \\
\text { of } \\
\text { Samples }\end{array}$ & Minimum & Maximum & $\begin{array}{c}\text { Tritium } \\
\text { nCil }\end{array}$ & $\begin{array}{c}\text { Average as a } \\
\text { Averagea,b of the EPA } \\
\text { StandardC }\end{array}$ \\
\hline 0904 & J-1 & 10 & 0.63 & 1.29 & $0.88 \pm 0.16$ & 4.4 \\
0905 & Tr-1 & 10 & $\mathrm{~d}$ & 0.50 & $0.29 \pm 0.11$ & 1.5 \\
0906 & B-R & 8 & 2.36 & 4.04 & $3.26 \pm 0.48$ & 16.3 \\
0907 & B-H & 8 & 1.58 & 2.54 & $2.19 \pm 0.24$ & 11.0 \\
0909 & MCD & 12 & $\mathrm{~d}$ & 0.45 & $0.24 \pm 0.08$ & 1.2 \\
0912 & MSBG2 & 44 & 0.97 & 6.55 & $3.62 \pm 0.43$ & 18.1 \\
0913 & MSBG3 & 12 & 0.99 & 5.19 & $2.13 \pm 0.87$ & 4.4 \\
\hline
\end{tabular}

a Error limits are estimates of the standard error of the estimated means at the $95 \%$ confidence level.

$b$ LDL for tritium in private well waters is $0.7 \mathrm{nCil}$.

c The EPA standard for tritium in drinking water is $20 \mathrm{nCi} / \mathrm{L}$.

d Below reagent blank.

* Well locations are shown on Figure 6-2. 


\section{Tritium in Community Drinking Water Supplies}

Tritium is the most mobile of the radionuclides released from the Plant. For this reason, Mound also monitors tritium concentrations in a number of regional groundwater supplies. The results for 1993 are presented in Table 6-2. The table shows that all of the values were near or below the lower limit of detection. However, the results, reflect the pattern of tritium concentrations one would expect: highest averages near the site (Miamisburg, Franklin) and lowest averages at greater distances (e.g., Bellbrook, Middletown).

\section{Tritium in Offsite Monitoring Wells}

To provide additional information on the extent of offsite tritium migration, Mound also collects groundwater samples from a number of offsite monitoring wells. The results for 1993 are shown in Table 6-3. (The data in Table 6-3 have not been presented as percentages of the EPA drinking water standard because these wells are used exclusively for monitoring purposes.) The 1993 data confirm that the tritium contamination is minor.

Table 6-2. Tritium Concentrations in Community Drinking Water Supplies in 1993

\begin{tabular}{|c|c|c|c|c|c|c|}
\hline Location* & $\begin{array}{l}\text { Number } \\
\text { of } \\
\text { Samples }\end{array}$ & \multicolumn{3}{|c|}{$\begin{array}{c}\text { Tritium } \\
\mathrm{nCi} / \mathrm{L}\end{array}$} & $\begin{array}{l}\text { Average as } \\
\text { a percent } \\
\text { of the EPA } \\
\text { Standardc }\end{array}$ & \\
\hline Bellbrook & 12 & d & 0.09 & $d$ & $d$ & \\
\hline Centerville & 12 & $d$ & 0.18 & $0.01 \pm 0.07$ & 0.05 & \\
\hline Dayton & 12 & $d$ & 0.14 & d & $d$ & \\
\hline Franklin & 12 & $d$ & 0.19 & $0.06 \pm 0.05$ & 0.3 & \\
\hline Germantown & 12 & $d$ & 0.15 & d & $d$ & \\
\hline Kettering & 12 & $d$ & 0.10 & d & $d$ & \\
\hline Miamisburg & 12 & 0.06 & 0.49 & $0.30 \pm 0.07$ & 1.5 & \\
\hline Middletown & 12 & $d$ & 0.14 & $d$ & $d$ & \\
\hline Moraine & 12 & $d$ & 0.15 & $d$ & $d$ & \\
\hline Springboro & 12 & $d$ & 0.46 & $0.18 \pm 0.11$ & 0.9 & \\
\hline Waynesville & 12 & d. & 0.23 & $0.02 \pm 0.08$ & 0.1 & \\
\hline W. Carrollton & 12 & $d$ & 0.17 & $0.05 \pm 0.06$ & 0.3 & \\
\hline
\end{tabular}

a Error limits are estimates of the standard error of the estimated means at the $95 \%$ confidence level.

b LDL for tritium in community drinking water is $0.7 \mathrm{nCi} / \mathrm{L}$.

c EPA drinking water standard for tritium is $20 \mathrm{nCi} / \mathrm{L}$; this standard is applied to total, not incremental, concentrations of tritium.

d Below reagent blanks.

* Sampling locations shown on Figure 4-11. 
Table 6-3. Tritium Concentrations in Offsite Monitoring Wells in 1993

\begin{tabular}{|c|c|c|c|c|c|}
\hline Well & Historic & $\begin{array}{c}\text { Number } \\
\text { of }\end{array}$ & & $\begin{array}{c}\text { Tritium } \\
\mathrm{nCi} / \mathrm{L}\end{array}$ & \\
\hline I.D.* & Designation & Samples & Minimum & Maximum & Average $^{a}$ \\
\hline 0002 & OW-2 & 3 & 5.94 & 9.62 & $7.45 \pm 4.79$ \\
\hline 0003 & OW-3 & 4 & 0.78 & 2.93 & $1.60 \pm 1.60$ \\
\hline 0004 & OW-4 & 2 & 2.12 & 2.29 & $2.21 \pm 1.08$ \\
\hline 0005 & OW-5 & 12 & 1.11 & 1.92 & $1.53 \pm 0.16$ \\
\hline 0006 & OW-6 & 4 & 4.62 & 5.19 & $4.87 \pm 0.38$ \\
\hline 0101 & $O W-1 A$ & 12 & 3.82 & 4.38 & $4.03 \pm 0.11$ \\
\hline 0106 & $O W-6 A$ & 12 & 0.10 & 0.38 & $0.21 \pm 0.05$ \\
\hline 0118 & & 2 & 0.63 & 0.96 & $0.80 \pm 0.17$ \\
\hline 0123 & & 2 & 0.52 & 0.20 & $0.36 \pm 0.16$ \\
\hline 0129 & & 2 & 1.93 & 1.06 & $1.50 \pm 0.44$ \\
\hline 0160 & & 2 & 0.34 & 0.23 & $0.29 \pm 0.06$ \\
\hline
\end{tabular}

a LDL for tritium in monitoring wells is $0.7 \mathrm{nCi} / \mathrm{L}$.

* Well locations shown on Figure 6.2. 


\section{Offsite Monitoring Activities for Other Radionuclides}

Private well waters in the immediate vicinity of the Plant are also analyzed for plutonium-238, plutonium-239,240, uranium-233,234, and uranium-238. Results for 1993 are shown in Tables $6-4$ and $6-5$ for plutonium and uranium, respectively. Averages reported in both tables demonstrate that concentrations measured in 1993 were comparable to background levels for these radionuclides. (Background levels for 1993 are also listed in the tables.)

Table 6-4. Plutonium Concentrations in Offsite Drinking Water and an Offsite Private Well in 1993

\begin{tabular}{|c|c|c|c|c|c|c|}
\hline \multirow{2}{*}{$\begin{array}{l}\text { Well } \\
\text { I.D.* }\end{array}$} & \multirow{2}{*}{$\begin{array}{l}\text { Historic } \\
\text { Designation }\end{array}$} & \multirow{2}{*}{$\begin{array}{l}\text { Number } \\
\text { of } \\
\text { Samples }\end{array}$} & \multicolumn{3}{|c|}{$\begin{array}{l}\text { Plutonium-238 } \\
10^{-12} \mu \mathrm{Ci} / \mathrm{mL}\end{array}$} & \multirow{2}{*}{$\begin{array}{l}\text { Average as a \% } \\
\text { of } 0.04 \times \text { the } \\
\text { DOE DCGd }\end{array}$} \\
\hline & & & Minimum & Maximum & Average $a, b, c$ & \\
\hline
\end{tabular}

$\begin{array}{llllcc}\text { Miamisburg water supply } & 12 & e & 2.60 & 0.02 \pm 1.10 & 0.001 \\ 0904 \quad \mathrm{~J}-1 & 10 & e & 1.43 & e & e\end{array}$

\begin{tabular}{|c|c|c|c|c|c|c|}
\hline \multirow{2}{*}{$\begin{array}{l}\text { Well } \\
\text { I.D.* }\end{array}$} & \multirow{2}{*}{$\begin{array}{l}\text { Historic } \\
\text { Designation }\end{array}$} & \multirow{2}{*}{$\begin{array}{l}\text { Number } \\
\text { of } \\
\text { Samples }\end{array}$} & \multicolumn{3}{|c|}{$\begin{array}{c}\text { Plutonium-239,240 } \\
10^{-12} \mu \mathrm{Ci} / \mathrm{mL}\end{array}$} & \multirow{2}{*}{$\begin{array}{c}\text { Average as a \% } \\
\text { of } 0.04 \times \text { the } \\
\text { DOE DCGd }\end{array}$} \\
\hline & & & Minimum & Maximum & Average $^{a, b, c}$ & \\
\hline \multicolumn{2}{|c|}{ Miamisburg water supply } & 12 & e & 4.18 & $0 . .39 \pm 0.89$ & 0.03 \\
\hline 0904 & $\mathrm{~J}-1$ & 10 & $\theta$ & 2.28 & $\bar{\theta}$ & $\boldsymbol{\theta}$ \\
\hline
\end{tabular}

a Error limits are estimates of the standard error of the estimated means at the $95 \%$ confidence level.

$b$ LDL for plutonium-238 in well water is $6.3 \times 10^{-12} \mu \mathrm{Ci} / \mathrm{mL}$. LDL for plutonium-239 in well water is $3.3 \times 10^{-12} \mu \mathrm{Ci} / \mathrm{mL}$.

$c^{c}$ Background concentration of plutonium-238 in 1993 averaged $1.20 \pm 3.35 \times 10^{-12} \mu \mathrm{Ci} / \mathrm{mL}$. Background concentration of plutonium-239 in 1993 averaged $0.66 \pm 0.67 \times 10^{-12} \mu \mathrm{Ci} / \mathrm{mL}$.

d DOE DCGs correspond to doses of $100 \mathrm{mrem} / \mathrm{yr}$. Since the EPA dose standard is $4 \mathrm{mrem} / \mathrm{yr}$, the averages have been reported as percentages of $0.04 \times$ the DCGs. $0.04 \times$ the DCG for plutonium-238 and $0.04 \times$ the DOE DCG for plutonium-239 are $1600 \times 10^{-12} \mu \mathrm{Ci} / \mathrm{mL}$ and $1200 \times 10^{-12} \mu \mathrm{Ci} / \mathrm{mL}$, respectively.

e Below reagent blank.

* Well locations are shown on Figure 6-2. 
The results from additional plutonium and uranium sampling exercises conducted in 1993 have not been included in Tables 6-4 and 6-5. Specifically, two samples were taken from Wells 0118,0123 , 0129 , and 160.

All of the plutonium-238 and plutonium-239,240 results were below the lower detection limits (LDLs). The LDLs for Pu-238 and Pu-239,240 were $0.01 \mathrm{pCi} / \mathrm{L}$ and $0.005 \mathrm{pCi} / \mathrm{L}$, respectively.
The uranium-233,234 results for the four wells ranged from $0.06 \mathrm{pCi} / \mathrm{L}$ (Well 0160 ) to $0.29 \mathrm{pCiL}$ (Well 0118). The uranium-238 results ranged from below the LDL (Well 0160) to $0.23 \mathrm{pCi} / \mathrm{L}$ (Well 0118). The LDL for uranium-238 is 0.03 $\mathrm{pCi} / \mathrm{L}$.

For purposes of comparing the data described above with the values in Tables 6-4 and 6-5, note that $1 \mathrm{pCi} / L=10^{-9} \mu \mathrm{Ci} / \mathrm{mL}$.

Table 6-5. Uranium Concentrations in Offsite Drinking Water and an Offsite Private Well in 1993

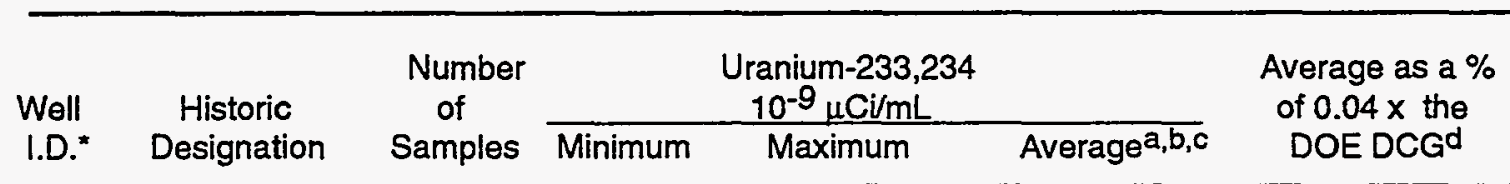

$\begin{array}{llllll}\text { Miamisburg water supply } & 12 & 0.28 & 0.51 & 0.41 \pm 0.05 & 2.1 \\ 0904 \quad \mathrm{~J}-1 & 10 & 0.13 & 0.21 & 0.17 \pm 0.02 & 0.7\end{array}$

\begin{tabular}{|c|c|c|c|c|c|c|}
\hline $\begin{array}{l}\text { Well } \\
\text { I.D.* }\end{array}$ & $\begin{array}{c}\text { Historic } \\
\text { Designation }\end{array}$ & $\begin{array}{l}\text { Number } \\
\text { of } \\
\text { Samples }\end{array}$ & Minimum & $\begin{array}{l}\text { Uranium-238 } \\
10^{-9} \mu \mathrm{Ci} / \mathrm{mL}\end{array}$ & Average $a, b, c$ & $\begin{array}{c}\text { Average as a \% } \\
\text { of } 0.04 \times \text { the } \\
\text { DOE DCGd }\end{array}$ \\
\hline \multicolumn{2}{|c|}{ Miamisburg water supply } & 12 & 0.30 & 0.43 & $0.36 \pm 0.03$ & 1.8 \\
\hline 0904 & J-1 & 10 & 0.12 & 0.16 & $0.14 \pm 0.01$ & 0.6 \\
\hline
\end{tabular}

a Error limits are estimates of the standard error of the estimated means at the $95 \%$ confidence level.

b LDL for uranium-233,234 is $0.06 \times 10^{-9} \mu \mathrm{Ci} / \mathrm{mL}$; the LDL for uranium-238 is $0.02 \times 10^{-9} \mu \mathrm{Ci} / \mathrm{mL}$.

c Background concentrations for uranium-233,234 and uranium-238 in 1993 averaged $0.28 \pm 0.02 \times 10^{-9}$ $\mu \mathrm{Ci} / \mathrm{mL}$ and $0.20 \pm 0.01^{\prime} \times 10^{-9} \mu \mathrm{Ci} / \mathrm{mL}$, respectively.

d DOE DCGs correspond to doses of $100 \mathrm{mrem} / \mathrm{yr}$. Since the EPA dose standard is $4 \mathrm{mrem} / \mathrm{yr}$, the averages have been reported as percentages of $0.04 \times$ the DCGs. $0.04 \times$ the DCG for uranium233,234 and $0.04 \times$ the DOE DCG for uranium-238 are $20 \times 10^{-9} \mu \mathrm{Ci} / \mathrm{mL}$ and $24 \times 10^{-9} \mu \mathrm{Ci} / \mathrm{mL}$, respectively.

Well locations are shown on Figure 6-2. 


\section{VOCs in Offsite Monitoring Wells}

The offsite monitoring wells are also used to evaluate concentrations of volatile organic compounds (VOCs). VOCs of concern at industrial sites are typically halogenated solvents such as 1,1,1-trichloroethane, trichloroethene, tetrachloroethene, and cis-1,2-dichloroethene. Concentrations of these compounds measured in offsite monitoring wells in 1993 are presented in Table 6-6. The table also lists the Maximum
Contaminant Level (MCL) for 1,1,1trichloroethane. However, MCLs are not truly applicable to these samples. MCLs are used by the EPA to ensure compliance with the Primary Drinking Water Standards. Since the samples do not represent drinking water, the MCLs should only be used to help put the observed concentrations in perspective.

Table 6-6. VOC Concentrations in Offsite Monitoring Wells in 1993

\begin{tabular}{|c|c|c|c|c|}
\hline \multirow{2}{*}{$\begin{array}{l}\text { Well } \\
\text { I.D.* }\end{array}$} & \multirow[b]{2}{*}{ Compound } & \multicolumn{3}{|c|}{$\mu \mathrm{g} / \mathrm{L}$} \\
\hline & & 1st Quarter & 3rd Quarter & $\mathrm{MCL}^{\mathrm{a}}$ \\
\hline 0118 & No compounds detected & -- & --- & --- \\
\hline 0123 & No compounds detected & --- & -.- & --- \\
\hline 0129 & 1,1,1-Trichloroethane & 3.2 & $1.3(R)$ & 200 \\
\hline 0160 & No compounds detected & -- & -- & -- \\
\hline
\end{tabular}

a $\mathrm{MCL}=$ Maximum Contaminant Level (based on EPA Primary Drinking Water Standards). $(R)=$ The data point is unusable. (Compound may or may not be present.)

* Well locations shown on Figure 6.2. 


\subsection{Onsite Groundwater Monitoring Program}

The onsite groundwater monitoring program at Mound consists of routine collection of samples from production wells andBVA monitoring wells. Samples are collected and analyzed primarily for radionuclides and volatile organic compounds (VOCs). Data from the groundwater analyses performed in 1993 are presented below. Sampling and analytical procedures used to generate these results are documented in Mound's Environmental Monitoring Plan (1994) and Mound's Groundwater Protection Management Program Plan (DOE 1993b).

\section{Tritium in Mound's Production Wells}

There are three deep wells onsite which provide drinking water and process water for the Mound Plant. Tritium concentrations in those wells are evaluated on a monthly basis. The results for 1993 are summarized in Table 6-7. As seen in the table, elevated levels of tritium are associated with the wells. However, the maximum concentration observed, $3.2 \mathrm{nCi}$ of tritium per liter of water, represents only $16 \%$ of the drinking water standard.

Table 6-7. Tritium Concentrations in Onsite Production Wells in 1993

\begin{tabular}{|c|c|c|c|c|c|c|}
\hline \multirow{2}{*}{$\begin{array}{l}\text { Well } \\
\text { I.D.* }\end{array}$} & \multirow{2}{*}{$\begin{array}{c}\text { Historic } \\
\text { Designation }\end{array}$} & \multirow{2}{*}{$\begin{array}{l}\text { Number } \\
\text { of } \\
\text { Samples }\end{array}$} & \multicolumn{3}{|c|}{$\begin{array}{c}\text { Tritium } \\
\text { nCil }\end{array}$} & \multirow{2}{*}{$\begin{array}{l}\text { Average as a } \\
\% \text { of the EPA } \\
\text { Standardc }\end{array}$} \\
\hline & & & Minimum & Maximum & Average $^{a, b}$ & \\
\hline 0071 & No. 1 & 40 & 0.7 & 3.2 & $1.4 \pm 0.2$ & 7.0 \\
\hline 0271 & No. 2 & 39 & 0.7 & 2.1 & $1.6 \pm 0.1$ & 8.0 \\
\hline 0076 & No. 3 & 46 & 0.6 & 1.7 & $1.1 \pm 0.1$ & 5.5 \\
\hline
\end{tabular}

a Error limits are estimates of the standard error of the estimated means at the $95 \%$ confidence level.

b LDL for tritium in onsite well water is $0.6 \mathrm{nCi} / \mathrm{L}$.

c The EPA standard for tritium in drinking water is $20 \mathrm{nCi}$.

- Well locations are shown on Figure 6-2.

\section{Tritium in the BVA}

Mound maintains an extensive network of onsite Buried Valley Aquifer (BVA) monitoring wells (Figure 6-2). Samples from a number of these wells are collected and analyzed for tritium. The results for 1993 are listed in Table 6-8. Data from Table 6-8 and from previous years demonstrate that some degree of tritium contamination is present in the aquifer.
The maximum concentration observed in 1993 was $33.5 \mathrm{nCi} / \mathrm{L}$ (Well 0120, located near WD Building). This value would be considered unacceptable from the perspective of the drinking water standard for tritium. However, the value was encountered in a monitoring well. Therefore, the drinking water standard does not apply and higher values (relative to production wells) are to be expected. 
Table 6-8. Tritium Concentrations in Onsite Monitoring Wells in 1993

\begin{tabular}{|c|c|c|}
\hline \multirow{2}{*}{$\begin{array}{l}\text { Well } \\
\text { I.D.* }\end{array}$} & \multicolumn{2}{|c|}{$\begin{array}{l}\text { Tritium } \\
\mathrm{nCi} / \mathrm{L}\end{array}$} \\
\hline & 1st Quarter & 3rd Quarter \\
\hline 0063 & 5.99 & 4.54 \\
\hline 0120 & 25.74 & 33.5 \\
\hline 0155 & 1.90 & 2.14 \\
\hline 0305 & 6.65 & 5.20 \\
\hline 0306 & 5.17 & 6.31 \\
\hline 0307 & 7.85 & 7.15 \\
\hline 0313 & 5.97 & 4.85 \\
\hline 0315 & 4.94 & 5.66 \\
\hline 0318 & 2.70 & 2.85 \\
\hline
\end{tabular}

* Well locations shown on Figure 6.2. 


\section{Tritium in the Seeps}

Tritium has been recognized as a persistent contaminant in the Main Hill seeps since 1986 (DOE 1987). Since then, tritium has been the focus of extensive sampling activities in that area. Table 6-9 shows concentrations of tritium in seep samples for 1993. (Seep locations are shown on Figure 6-6.) The highest tritium concentrations are clearly associated with Seep 601 . This result is consistent with observations in previous years.
Remediation of the seeps is being addressed through Mound's CERCLA Program. The seeps are included in Operable Unit 2 of the environmental restoration (ER) program established for Mound. An overview of the status of the ER Program appears in Section 3.7 of this report.

Table 6-9. Tritium Concentrations in Seeps in 1993

\begin{tabular}{cccccc}
\hline $\begin{array}{c}\text { Seep } \\
\text { I.D.* }\end{array}$ & $\begin{array}{c}\text { Historic } \\
\text { Designation }\end{array}$ & $\begin{array}{c}\text { Number } \\
\text { of } \\
\text { Samples }\end{array}$ & Minimum & Maximum & Average \\
\hline 0601 & S001 & 208 & 45.9 & 308.2 & 152.1 \\
0602 & S002 & 13 & 3.6 & 25.2 & 13.5 \\
0605 & S005 & 11 & 13.9 & 88.4 & 62.2 \\
0606 & S006 & 10 & 6.1 & 64.4 & 29.8 \\
0607 & S007 & 116 & 6.4 & 25.2 & 17.6 \\
\hline
\end{tabular}

- Seep locations are shown on Figure 6-6. 


\section{Figure 6-6. Seep and Capture Pit Sampling Locations}

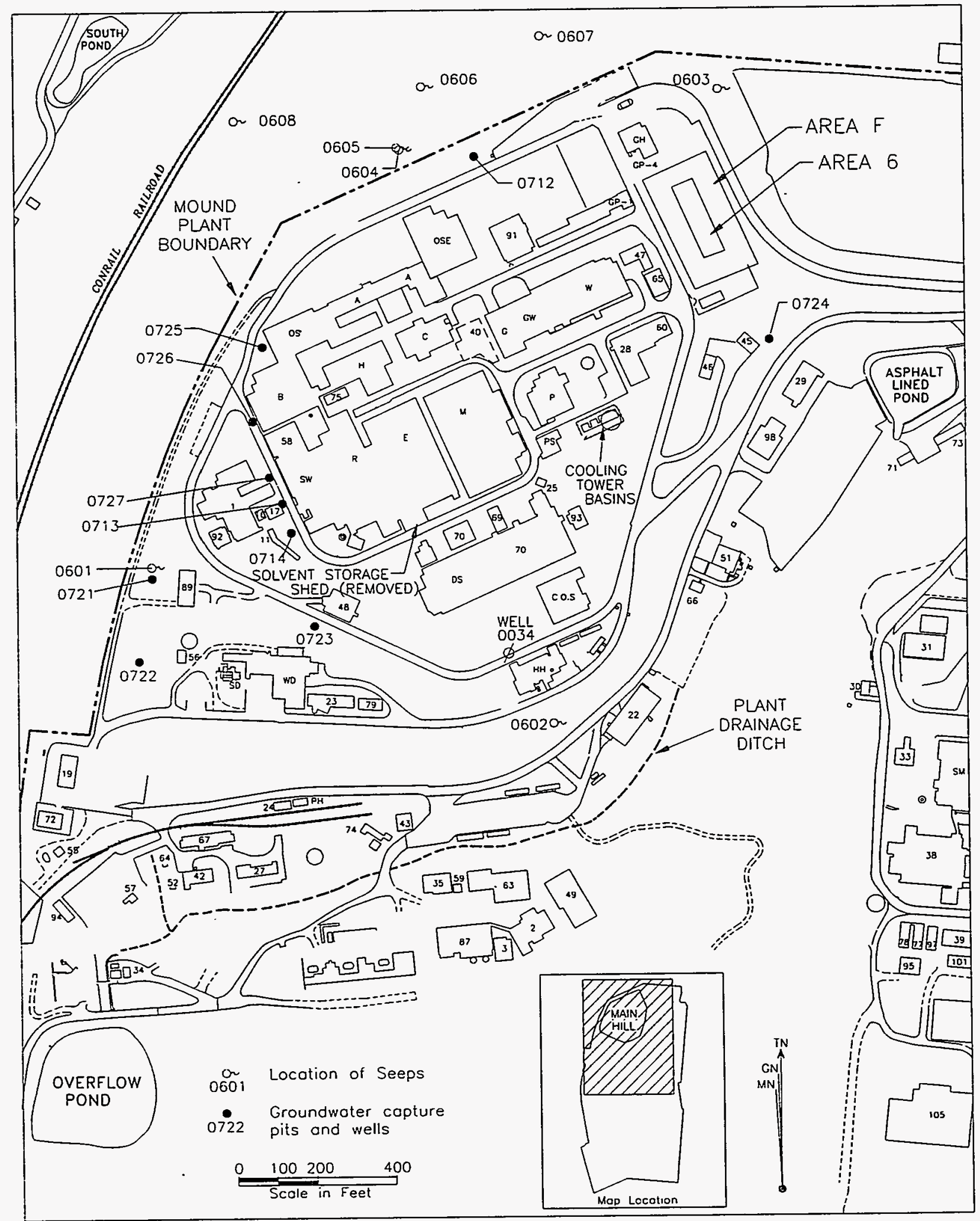




\section{Tritium in the Capture Pits}

A number of groundwater collection devices, or "capture pits", are used on the Main Hill to isolate and monitor contamination in perched groundwater. These devices have been designed to collect pockets of shallow groundwater which may have been contaminated as a result of past operational practices.
In 1993, numerous samples were collected from the pits and analyzed for tritium. The results are shown in Table 6-10. The locations of the sampling points for the capture pits are shown on Figure 66.

Table 6-10. Tritium Concentrations in the Capture Pits in 1993

\begin{tabular}{lccccc}
\hline $\begin{array}{l}\text { Capture Pit } \\
\text { I.D.* }\end{array}$ & $\begin{array}{c}\text { Historic } \\
\text { Designation }\end{array}$ & $\begin{array}{c}\text { Number } \\
\text { of } \\
\text { Samples }\end{array}$ & Minimum & Maximum & Average \\
\hline 0712 & P012 & 28 & 0.9 & 3.5 & 2.0 \\
0714 & P014 & 78 & 175.5 & 589.9 & 364.0 \\
0725 & W005 & 115 & 1.4 & 236.8 & 5.8 \\
0726 & W006 & 119 & 3.8 & 611.4 & 159.0 \\
0727 & W007 & 72 & 4.6 & 844.8 & 334.1 \\
\hline
\end{tabular}

* Capture pit locations are shown on Figure 6-6. 


\section{Onsite Monitoring Activities for Other Radionuclides}

Samples collected from the Plant's three production wells are also analyzed for plutonium238, plutonium-239,240, uranium-233,234, and uranium-238. Results for 1993 are shown in Tables 6-11 and 6-12 for plutonium and uranium, respectively. Averages reported in both tables demonstrate that average concentrations measured in 1993 were comparable to background levels for these radionuclides. (Background levels for 1993 are also listed in the tables.)

Table 6-11. Plutonium Concentrations in Onsite Production Wells in 1993

\begin{tabular}{lcccccc}
\hline Well & $\begin{array}{c}\text { Historic } \\
\text { 1.D.* }\end{array}$ & $\begin{array}{c}\text { Number } \\
\text { of } \\
\text { Designation }\end{array}$ & Samples & Minimum & $\begin{array}{c}\text { Plutonium-238 } \\
10^{-12} \mu \mathrm{Ci} / \mathrm{mL}\end{array}$ & $\begin{array}{c}\text { Average as a } \\
\text { Maximum of 0.04 X } \\
\text { the DOE DCGd }\end{array}$ \\
\hline 0071 & No.1 & 11 & $e$ & 3.28 & $0.88 \pm 0.95$ & 0.06 \\
0271 & No.2 & 10 & $e$ & 4.03 & $0.46 \pm 1.39$ & 0.03 \\
0076 & No.3 & 12 & $e$ & 3.00 & $0.47 \pm 0.87$ & 0.03
\end{tabular}

\begin{tabular}{|c|c|c|c|c|c|c|}
\hline \multirow{2}{*}{$\begin{array}{l}\text { Well } \\
\text { I.D." }\end{array}$} & \multirow{2}{*}{$\begin{array}{c}\text { Historic } \\
\text { Designation }\end{array}$} & \multirow{2}{*}{$\begin{array}{l}\text { Number } \\
\text { of } \\
\text { Samples }\end{array}$} & \multicolumn{3}{|c|}{$\begin{array}{l}\text { Plutonium-239,240 } \\
10^{-12} \mu \mathrm{Ci} / \mathrm{mL}\end{array}$} & \multirow{2}{*}{$\begin{array}{l}\text { Average as a } \\
\% \text { of } 0.04 \times \\
\text { the DOE DCG }\end{array}$} \\
\hline & & & Minimum & Maximum & Average $e^{a, b, c}$ & \\
\hline 0071 & No. 1 & 11 & $e$ & 2.45 & $0.82 \pm 0.70$ & 0.07 \\
\hline 0271 & No. 2 & 10 & $e$ & 3.35 & $0.60 \pm 0.90$ & 0.05 \\
\hline 0076 & No. 3 & 12 & $\theta$ & 1.15 & $0.20 \pm 0.47$ & 0.02 \\
\hline
\end{tabular}

a Error limits are estimates of the standard error of the estimated means at the $95 \%$ confidence level.

$b$ LDL for plutonium-238 in drinking water is $6.3 \times 10^{-12} \mu \mathrm{Ci} / \mathrm{mL}$; the $\mathrm{LDL}$ for plutonium-239 in drinking water is $3.3 \times 10^{-12} \mu \mathrm{Ci} / \mathrm{mL}$.

c Background concentrations for plutonium-238 and plutonium-239 in 1993 averaged $1.20 \pm 3.35 \times 10^{-12}$ $\mu \mathrm{Ci} / \mathrm{mL}$ and $0.66 \pm 0.67 \times 10^{-12} \mu \mathrm{Ci} / \mathrm{mL}$, respectively.

d DOE DCGs correspond to doses of $100 \mathrm{mrem} / \mathrm{yr}$. Since the EPA dose standard is $4 \mathrm{mrem} / \mathrm{yr}$, the averages have been reported as percentages of $0.04 \times$ the DCGs. $0.04 \times$ the DCG for plutonium238 and $0.04 \times$ the DOE DCG for plutonium-239 are $1600 \times 10^{-12} \mu \mathrm{Ci} / \mathrm{mL}$ and $1200 \times 10^{-12} \mu \mathrm{Ci} / \mathrm{mL}$, respectively.

Q Below reagent blank.

- Well locations are shown on Figure 6-2. 
Table 6-12. Uranium Concentrations in Onsite Production Wells in 1993

\begin{tabular}{|c|c|c|c|c|c|c|}
\hline \multirow{2}{*}{$\begin{array}{l}\text { Well } \\
\text { I.D.* }\end{array}$} & \multirow{2}{*}{$\begin{array}{l}\text { Historic } \\
\text { Designation }\end{array}$} & \multirow{2}{*}{$\begin{array}{l}\text { Number } \\
\text { of } \\
\text { Samples }\end{array}$} & \multicolumn{3}{|c|}{$\begin{array}{c}\text { Uranium-233,234 } \\
10^{-9} \mu \mathrm{Ci} / \mathrm{mL}\end{array}$} & \multirow{2}{*}{$\begin{array}{l}\text { Average as a } \\
\% \text { of } 0.04 \times \\
\text { the DOE DCGC }\end{array}$} \\
\hline & & & Minimum & Maximum & Average $\mathrm{a}, \mathrm{b}$ & \\
\hline 0071 & No. 1 & 11 & 0.20 & 0.26 & $0.22 \pm 0.01$ & 1.1 \\
\hline 0271 & No. 2 & 10 & 0.14 & 0.23 & $0.19 \pm 0.02$ & 1.0 \\
\hline 0076 & No. 3 & 12 & 0.19 & 0.27 & $0.23 \pm 0.02$ & 1.2 \\
\hline
\end{tabular}

\begin{tabular}{lcccccc}
\hline $\begin{array}{c}\text { Well } \\
\text { I.D.* }\end{array}$ & $\begin{array}{c}\text { Historic } \\
\text { Designation }\end{array}$ & $\begin{array}{c}\text { Number } \\
\text { of } \\
\text { Samples }\end{array}$ & Minimum & $\begin{array}{c}\text { Uranium-238 } \\
10-9 \mu \mathrm{Ci} / \mathrm{mL}\end{array}$ & $\begin{array}{c}\text { Maximum } \\
\text { Average as a } \\
\text { the DOE DCGc }\end{array}$ \\
\hline 0071 & No.1 & 11 & 0.16 & 0.22 & $0.19 \pm 0.01$ & 0.8 \\
0271 & No.2 & 10 & 0.13 & 0.20 & $0.16 \pm 0.01$ & 0.7 \\
0076 & No.3 & 12 & 0.16 & 0.24 & $0.20 \pm 0.01$ & 0.8 \\
\hline
\end{tabular}

a Error limits are estimates of the standard error of the estimated means at the $95 \%$ confidence level.

$b$ LDL for uranium-233,234 in drinking water is $0.06 \times 10^{-9} \mu \mathrm{Ci} / \mathrm{mL}$; the $\mathrm{LDL}$ for uranium-238 in drinking water is $0.02 \times 10^{-9} \mu \mathrm{Ci} / \mathrm{mL}$.

c DOE DCGs correspond to doses of $100 \mathrm{mrem} / \mathrm{yr}$. Since the EPA dose standard is $4 \mathrm{mrem} / \mathrm{yr}$, the averages have been reported as percentages of $0.04 \times$ the DCGs. $0.04 \times$ the DCG for uranium233 and $0.04 \times$ the DOE DCG for uranium-238 are $20 \times 10^{-9} \mu \mathrm{Ci} / \mathrm{mL}$ and $24 \times 10^{-9} \mu \mathrm{Ci} / \mathrm{mL}$, respectively:

* Well locations are shown on Figure 6-2. 


\section{VOC Monitoring Activities}

Production wells. The Plant's drinking water supply is provided by three production wells. These wells have exhibited VOC contamination in the form of halogenated solvents. The five halogenated solvents typically present in trace concentrations are freon-113, 1, 1, 1trichloroethane, cis-1,2-dichloroethene, trichloroethene, and tetrachloroethene. Results for 1993 are shown in Table 6-13: As seen in the Table, the Plant continues to record trichloroethene levels above the MCL in Well 0071. Though the MCL was exceeded, the "running" annual average was $2.79 \mu \mathrm{g} / \mathrm{L}$. (The running annual average determines compliance with the SDWA.)

Well 0071 is used only in emergencies; consequently, it did not provide drinking water to the Plant in 1993. Nevertheless; this issue is carefully monitored since the production wells are located near a suspected source of VOC contamination.

Table 6-13. VOC Concentrations in Onsite Production Wells in 1993

\begin{tabular}{|c|c|c|c|c|c|c|}
\hline \multirow{2}{*}{$\begin{array}{l}\text { Well } \\
\text { I.D.* }\end{array}$} & \multirow[b]{2}{*}{ Compound } & \multirow{2}{*}{$\begin{array}{l}\text { No. of } \\
\text { Samples }\end{array}$} & \multirow[b]{2}{*}{ Minimum } & \multicolumn{2}{|c|}{$\mu \mathrm{g} / \mathrm{L}$} & \multirow[b]{2}{*}{$\overline{M C L^{2}}$} \\
\hline & & & & Maximum & Average & \\
\hline \multirow[t]{4}{*}{0071} & 1,1,1-Trichloroethane & 7 & N.D. & 1.4 & 0.20 & 200 \\
\hline & cis-1,2-Dichloroethene & 7 & 0.6 & 17.0 & 5.04 & 70 \\
\hline & Trichloroethene & 7 & 1.6 & 5.2 & 2.79 & 5 \\
\hline & Tetrachloroethene & 7 & N.D. & 0.7 & 0.17 & 5 \\
\hline \multirow[t]{5}{*}{0271} & Freon $113^{\circ}$ & 7 & N.D. & $3.0^{c}$ & 0.43 & d \\
\hline & $1,1,1$-Trichloroethane & 7 & N.D. & 1.2 & 0.33 & 200 \\
\hline & cis-1,2-Dichloroethene & 7 & N.D. & 7.2 & 2.29 & 70 \\
\hline & Trichloroethene & 7 & N.D. & 1.8 & 1.16 & 5 \\
\hline & Tetrachloroethene & 7 & N.D. & 0.5 & 0.07 & 5. \\
\hline \multirow[t]{4}{*}{0076} & Freon $113^{b}$ & 7 & N.D. & $2.0^{c}$ & 0.29 & $d$ \\
\hline & 1,1,1-Trichloroethane & 7 & N.D. & 0.6 & 0.09 & 200 \\
\hline & cis-1,2-Dichloroethene & 7 & 0.6 & 3.0 & 1.33 & 70 \\
\hline & Trichloroethene & 7 & 1.5 & 2.0 & 1.80 & 5 \\
\hline
\end{tabular}

a $\mathrm{MCL}=$ Maximum Contaminant Level (based on EPA Primary Drinking Water Standards).

- Freon $113=1,1,2$-trichloro-1,2,2-trifluoroethane.

c Freon 113 was detected twice, but the results were estimated and have not been included in this table.

- There is no MCL for freon 113.

N.D. = Not detected.

- Well locations shown on Figure 6.2. 


\section{Chapter 6}

BVA. Within the Mound Plant, numerous monitoring wells in the upper and lower units of the Buried Valley aquifer have been sampled routinely since 1988 . Results confirm the presence of VOC contamination in the aquifer. Based on routine sampling of the BVA monitoring network, the contamination appears to be greatest along the western Plant boundary, immediately southwest of the Main Hill. Generally, within the boundaries of the plant, the contamination tends to decrease from west to east and from north to south.

The results for 1993 are shown in Table 6-14. Trichloroethene and tetrachloroethene are the principal contaminants which exceed the MCL for drinking water. MCLs are used as guidelines to help put observed concentrations in perspective. The MCLs are not truly applicable to these wells, since the samples do not represent drinking water.

In 1993, 15 additional monitoring wells were installed in Operable Unit 1. These wells were sampled in the spring for inorganic and organic constituents. Five wells exhibited some degree of VOC contamination (Table 6-14). Significant amounts of VOCs were not detected in most of the other newly-installed and existing wells.

Table 6-14. VOC Concentrations in Onsite Monitoring Wells in 1993

\begin{tabular}{|c|c|c|c|c|}
\hline \multirow{2}{*}{$\begin{array}{l}\text { Well } \\
\text { I.D.* }\end{array}$} & \multirow[b]{2}{*}{ Compound } & \multicolumn{3}{|c|}{$\mu \mathrm{g} / \mathrm{L}$} \\
\hline & & 1st Quarter & 3rd Quarter & $\mathrm{MCL}^{\mathrm{a}}$ \\
\hline \multirow[t]{5}{*}{0063} & Freon $113^{b}$ & $2.5^{\mathrm{U}}$ & N.De & d \\
\hline & cis-1,2-Dichloroethene & $N / A^{c}$ & $3.1^{\mathrm{J}}$ & 70 \\
\hline & Trichloroethene & $N / A^{c}$ & $21^{J}$ & 5 \\
\hline & Tetrachloroethene & $N / A^{c}$ & $27^{J}$ & 5 \\
\hline & Tetrachloromethane & $N / A^{c}$ & 2.7 & 5 \\
\hline \multirow[t]{4}{*}{0155} & Freon $113^{b}$ & $1.4^{\mathrm{U}}$ & N.D. ${ }^{\circ}$ & d \\
\hline & Trichloroethene & $N / A^{c}$ & 3.5 & 5 \\
\hline & Trichloromethane & $N / A^{c}$ & 0.81 & 5 \\
\hline & cis-1,2-Dichloroethene & $N / A^{c}$ & 3.0 & 70 \\
\hline \multirow[t]{5}{*}{0305} & cis-1,2-Dichloroethene & 28.0 & 8.6 & 70 \\
\hline & Trichloroethene & 32.0 & 23.0 & 5 \\
\hline & Tetrachloroethene & 28.0 & 16.0 & 5 \\
\hline & Tetrachloromethane & $N . D^{e}$ & 1.6 & 5 \\
\hline & Trichloromethane & N.D & 3.6 & 5 \\
\hline
\end{tabular}

aCL = Maximum Contaminant Level (based on EPA Primary Drinking Water Standards).

b Freon $113=1,1,2$-trichloro-1,2,2-trifluoroethane.

c Not analyzed for this constituent.

d There is no MCL for Freon 113.

- N.D. = Not detected.

' N.S. = Not sampled during third quarter sweeps.

I Estimated quantity.

$\checkmark$ Suspect analysis due to interference problems.

* Well locations shown on Figure 6.2. 
Table 6-14. (continued)

$\begin{array}{ll}\text { Well } & \text { Compound } \\ 0306 & \begin{array}{l}\text { Dibromochloromethane } \\ \text { Trichloroethene } \\ \text { Tetrachloroethene } \\ \text { Xylenes, totalu }\end{array} \\ 0307 & \begin{array}{l}\text { Trichloroethene } \\ \text { Tetrachloroethene } \\ \text { Tetrachloromethane } \\ \text { Trichloromethane }\end{array}\end{array}$

0313

Dibromochloromethane
Trichloroethene
Tetrachloroethene
Tetrachloromethane
Xylenes, total

0315

Trichloroethene

Tetrachloromethane

cis-1,2-Dichloroethene

2.0

16.0

5.2

2.1

$\mu \mathrm{g} / \mathrm{L}$

\begin{tabular}{lll}
\hline 1st Quarter & 3rd Quarter & $\mathrm{MCL}^{\mathrm{a}}$
\end{tabular}

9.0

15.0

2.0

N.D. ${ }^{\circ}$

N.D

6.0

4.4

100

N.D

5

10

0

6.7

10

1.3

0.81

5

5

5

$2.4^{\mathrm{U}}$

6.6

11.0

1.5

$1.3^{u}$

N.D. ${ }^{\circ}$

3.5

7.5

N.D. ${ }^{\circ}$

5

7.2

3.6
N.D.

N.D.

100

5

5

5

10

8.6

3.1

5

1.5

5

70

0318

No compounds detected

0370

Freon-113
1,1,1-Trichloroethane
Chloroethene
cis-1,2-Dichloroethene
trans-1,2-Dichloroethene
Trichloroethene
Tetrachloroethene
N.D. ${ }^{\circ}$
$1.6^{\mathrm{J}}$
4.5
$640^{\mathrm{J}}$
$2.6^{\mathrm{J}}$
$.210^{\mathrm{J}}$
$270^{\mathrm{s}}$

$3.7^{3}$

$0.4^{J}$

$1.8^{\mathrm{J}}$

190

$1.1^{\mathrm{J}}$

$72^{\mathrm{J}}$

140

-.-

d

200

2

70

100

5

5

a $\mathrm{MCL}=$ Maximum Contaminant Level (based on EPA Primary Drinking Water Standards).

Freon $113=1,1,2$-trichloro-1,2,2-trifluoroethane.

c Not analyzed for this constituent.

- There is no MCL for Freon 113.

e N.D. = Not detected.

' N.S. = Not sampled during third quarter sweeps.

$\checkmark$ Estimated quantity.

"Suspect analysis due to interference problems.

* Well locations shown on Figure 6.2. 
Table 6-14. (continued)

\begin{tabular}{|c|c|c|c|c|}
\hline \multirow{2}{*}{$\begin{array}{l}\text { Well } \\
\text { I.D.* }\end{array}$} & \multirow[b]{2}{*}{ Compound } & \multicolumn{3}{|c|}{$\mu \mathrm{g} / \mathrm{L}$} \\
\hline & & 1st Quarter & 3rd Quarter & $\mathrm{MCL}^{\mathrm{a}}$ \\
\hline $\begin{array}{l}0370 \\
\text { (con'd) }\end{array}$ & $\begin{array}{l}\text { Fluorotrichloromethane } \\
\text { Trichloromethane } \\
\text { Tetrachloromethane }\end{array}$ & $\begin{array}{c}12 \\
130^{J} \\
4.6\end{array}$ & $\begin{array}{l}2.2^{\mathrm{J}} \\
25^{\mathrm{J}} \\
3.2^{\mathrm{J}}\end{array}$ & $\begin{array}{c}d \\
100 \\
5\end{array}$ \\
\hline 0373 & $\begin{array}{l}\text { Freon-113 } \\
\text { cis,1-2-Dichloroethene } \\
\text { Trichloroethene } \\
\text { Tetrachloroethene } \\
\text { Fluorotrichloromethane } \\
\text { Trichloromethane } \\
\text { Tetrachloromethane }\end{array}$ & $\begin{array}{l}\text { N.D.e } \\
17^{\jmath} \\
31^{\mathrm{J}} \\
40^{\mathrm{J}} \\
3.3^{\mathrm{J}} \\
13 \\
4.0\end{array}$ & $\begin{array}{l}5.2 \\
13^{J} \\
31^{J} \\
49^{\jmath} \\
3.2 \\
8.3^{j} \\
4.5^{J}\end{array}$ & $\begin{array}{c}d \\
70 \\
5 \\
5 \\
d \\
100 \\
5\end{array}$ \\
\hline 0374 & $\begin{array}{l}\text { Tetrachloroethene } \\
\text { Trichloroethene }\end{array}$ & $\begin{array}{l}23.0 \\
24.0\end{array}$ & $\begin{array}{l}\text { N.S.' } \\
\text { N.S.' }\end{array}$ & $\begin{array}{l}5 \\
5\end{array}$ \\
\hline 0375 & $\begin{array}{l}\text { Tetrachloroethene } \\
\text { Trichloroethene }\end{array}$ & $\begin{array}{l}5.3^{\jmath} \\
3.9^{J}\end{array}$ & $\begin{array}{l}4.8 \\
2.7\end{array}$ & $\begin{array}{l}5 \\
5\end{array}$ \\
\hline 0378 & $1,1,1$-Trichloroethane & 13.0 & $16.0^{J}$ & 200 \\
\hline 0379 & $\begin{array}{l}\text { Tetrachloromethane } \\
\text { Tetrachloroethene }\end{array}$ & $\begin{array}{l}3.4 \\
2.7\end{array}$ & $\begin{array}{l}2.6^{\mathrm{J}} \\
2.4^{\mathrm{J}}\end{array}$ & $\begin{array}{l}5 \\
5\end{array}$ \\
\hline & Trichloroethene & 2.8 & $1.4^{\mathrm{J}}$ & 5 \\
\hline 0397 & $\begin{array}{l}\text { Freon-113 } \\
\text { cis-1,2-Dichloroethene } \\
\text { Trichloroethene } \\
\text { Tetrachloroethene } \\
\text { Trichloromethane } \\
\text { Tetrachloromethane }\end{array}$ & $\begin{array}{l}\text { N.D. } \\
\text { N.D. } \\
8.9^{j} \\
12 \\
0.7^{j} \\
2.3^{j}\end{array}$ & $\begin{array}{c}2.1 \\
1.1 \\
11.0 \\
14.0 \\
0.9 \\
1.5\end{array}$ & $\begin{array}{c}d \\
70 \\
5 \\
5 \\
100 \\
5\end{array}$ \\
\hline
\end{tabular}

- MCL = Maximum Contaminant Level (based on EPA Primary Drinking Water Standards).

- Freon $113=1,1,2$-trichloro-1,2,2-trifluoroethane.

- Not analyzed for this constituent.

d There is no MCL for Freon 113.

- N.D. = Not detected.

' N.S. = Not sampled during third quarter sweeps.

$\checkmark$ Estimated quantity.

$\checkmark$ Suspect analysis due to interference problems.

- Well locations shown on Figure 6.2. 
Seeps. Samples collected from the Main Hill in 1988 first confirmed the presence of VOCs in Seeps 0601, 0602, 0605, and 0607 (EG\&GMound, 1991). (The seep locations were shown on Figure 6-6.) The seeps were sampled for VOCs during the 1993 sweep sampling campaign. Validation of the data had not been completed by the publication date of this report.

Capture pits. The capture pits were not sampled for VOCs in 1993.

\subsection{Five-Year Trends for Wells of Interest}

As seen in Sections 6.1 through 6.4 of this chapter, a large volume of groundwater monitoring data is generated each year for the Mound Plant. It is important that the data be reviewed for evidence of long-term trends, especially in cases where there is some history of elevated concentrations of contaminants. In this section, five-year trends are presented for certain indicator parameters measured in wells of interest.

\section{Trend Data for Offsite Drinking Water}

A primary environmental consideration for the Mound Plant is to ensure that area drinking water supplies are not adversely affected by Plant operations. The most mobile of the constituents released to groundwater by Mound is tritium. For this reason, tritium is an excellent indicator of offsite migration. Detailed information regarding tritium levels in offsite wells was presented in Section 6.3.

Among the wells listed in those sections, two drinking water sources can be considered key receptor wells. First, the drinking water supply of the City of Miamisburg is of interest due to the proximity of the City's well fields to the Plant. And second, Well 0904, a private well, is useful as an indicator because it reflects potential impact to small drinking water systems.
Five-year trends for tritium concentrations in the two wells described above are shown in Figure 67. As seen in the figure, tritium levels in the wells have exhibited little change during the period 1989 through 1993. Some evidence of a downward trend in tritium concentrations is evident for the private well, but the magnitude of change is small. All of the values shown on the graph are significantly below the drinking water standard for tritium, $20 \mathrm{nCi} / \mathrm{L}$.

\section{Trend Data for Onsite Production Wells and Seeps}

As previously described in this chapter, tritium and certain volatile organic compounds (VOCs) have been observed in the groundwater system underlying the Plant site. As discussed in Section 6.4 , VOCs of concern include trichloroethene, tetrachloroethene, and 1,2-dichloroethene. Trichloroethene is used in this section as an "indicator" VOC.

An appropriate onsite indicator well is Production WellNo. 3 (also referred to as Well 0076) because it serves as the primary source of drinking water for the Plant. Another important monitoring point for the evaluation of groundwater conditions is associated with the seep sites. Data collected to-date suggest Seep 0601 is an appropriate location for the observation of long-term trends.

Five-year trend data for Mound Production Well No. 3 are shown in Figures 6-8 and 6-9 for tritium and trichloroethene, respectively. Similarly, Figures 6-10 and 6-11 present five-year-trend data for tritium and trichloroethene at Seep 0601.

Figure 6-8 indicates that tritium levels in Mound Well No. 3 are well below the applicable drinking waterstandard $(20 \mathrm{nCi} / \mathrm{L})$ and are not significantly different from the values reported for offsite drinking water systems. Some evidence of a downward trend is suggested by the data. 
Figure 6-7. Annual Average Tritium Concentration in Offsite Drinking Water, 1989 - 1993

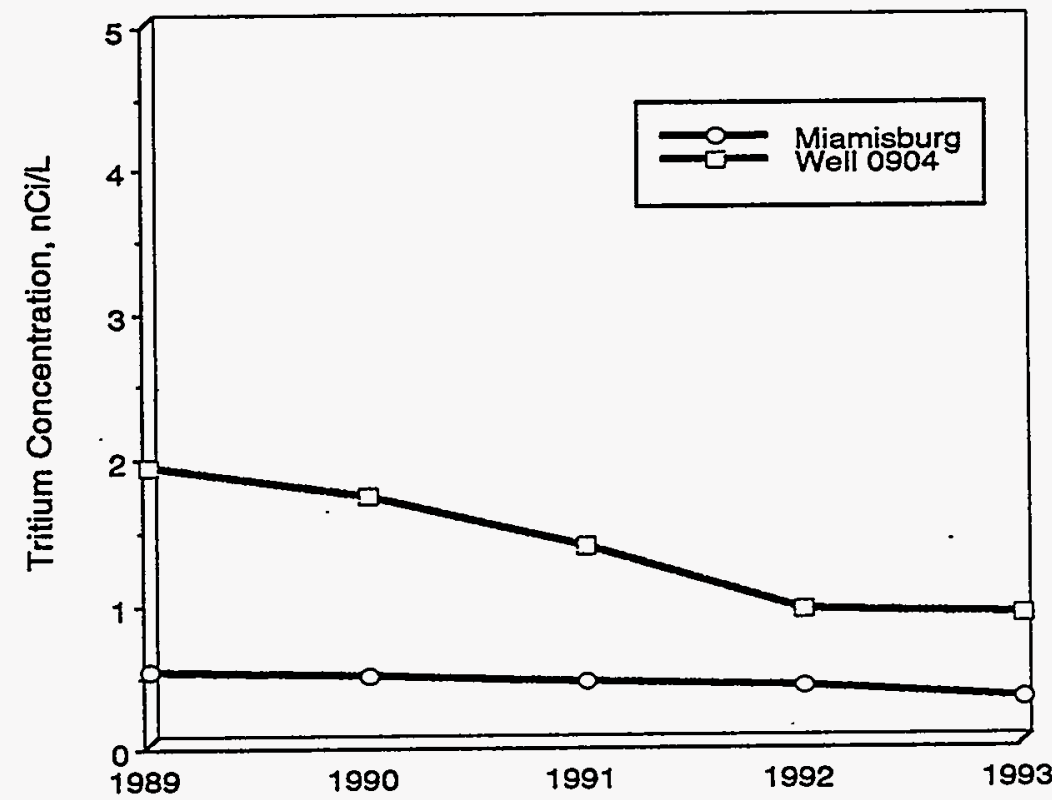

(Drinking water standard for tritium $=20 \mathrm{nCi} /$.)

Figure 6-8. Annual Average Tritium Concentration in Onsite Drinking Water, 1989 - 1993

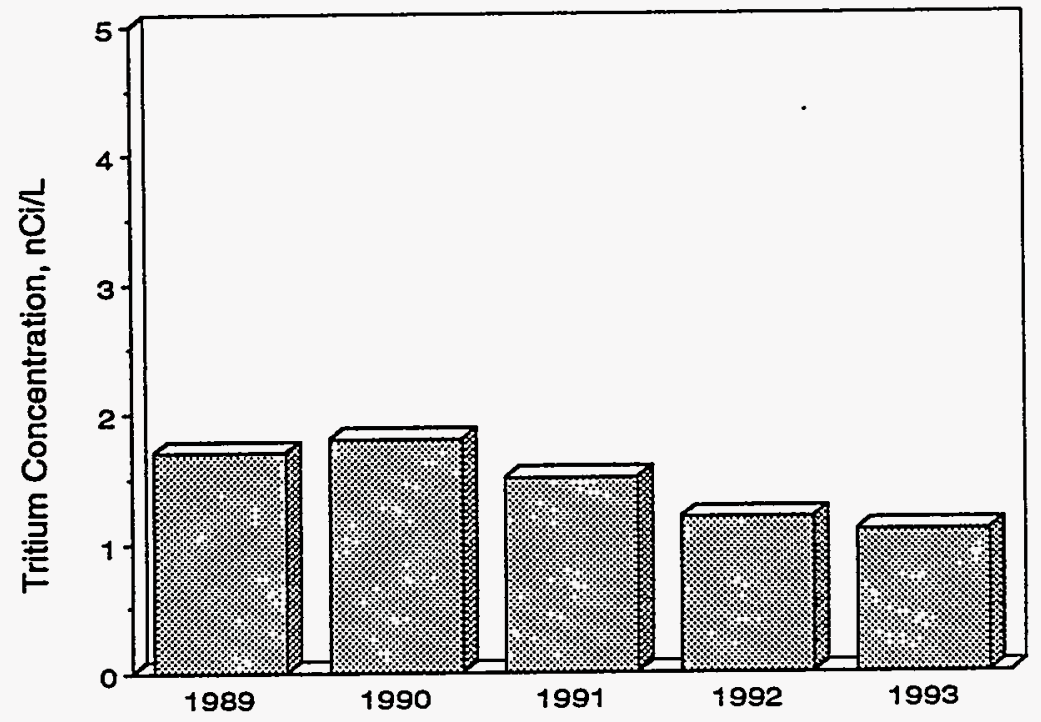

(Drinking water standard for tritium $=20 \mathrm{nCi} /$.) 
For the trichloroethene in Well No. 3 (Figure 69), slightly elevated concentrations have been observed. However, as documented by the footnote to the figure, observed concentrations have remained below the applicable MCL.

Figure 6-10 presents tritium concentration data for Seep 0601. Data for the period 1989-1993 show tritium concentrations ranging from approximately $100 \mathrm{nCi} / \mathrm{L}$ to just over $200 \mathrm{nCi} / \mathrm{L}$. From the figure, it can be noted that average concentrations have both increased and decreased over the five-year period shown. Additional data will be required to evaluate the presence or absence of a clear trend.
As seen in Figure 6-11, Seep 0601 is also characterized by elevated levels of trichloroethene. Additionally, though not shown in the figure, over the past few years tetrachloroethene has also emerged as a key contributor to VOC contamination in the seep.

Because Mound seep sites are not sources of drinking water, tritium levels above the drinking water standard, or VOC values in excess of a maximum contaminant level, should not be interpreted as indicative of a human health or environmental concern. Mound's Environmental Restoration (ER) Program will evaluate the risks associated with contamination in the seeps and will identify remediation actions which may be appropriate.

Figure 6-9. Annual Average Indicator VOC Concentration in Onsite Drinking Water, 1989 $-1993$

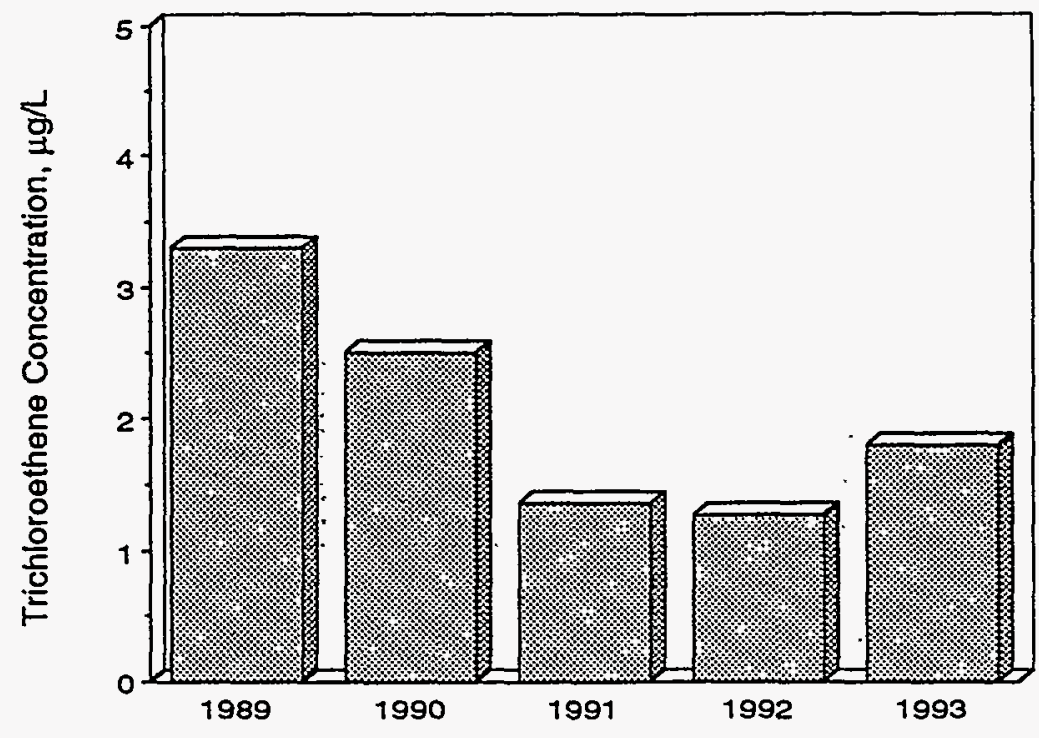

(MCL for trichloroethene $=5 \mu \mathrm{g} / \mathrm{L}$.) 
Figure 6-10. Annual Average Tritium Concentration for Seep 0601, 1989 - 1993

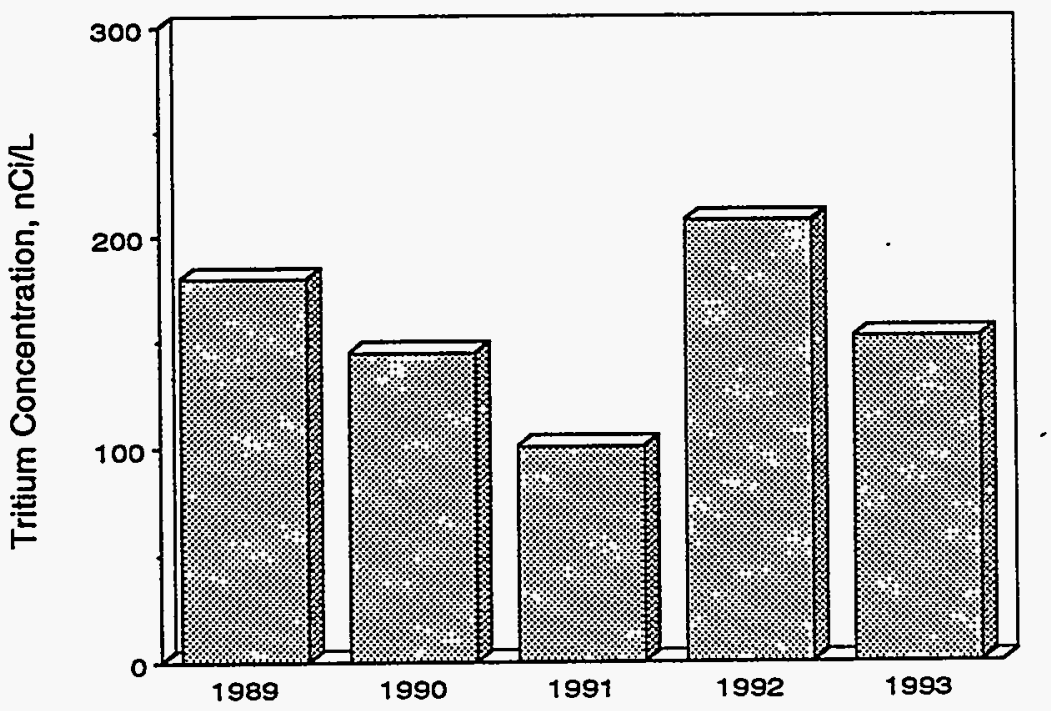

Figure 6-11. Annual Average Indicator VOC Concentration for Seep 0601, 1989 - 1993

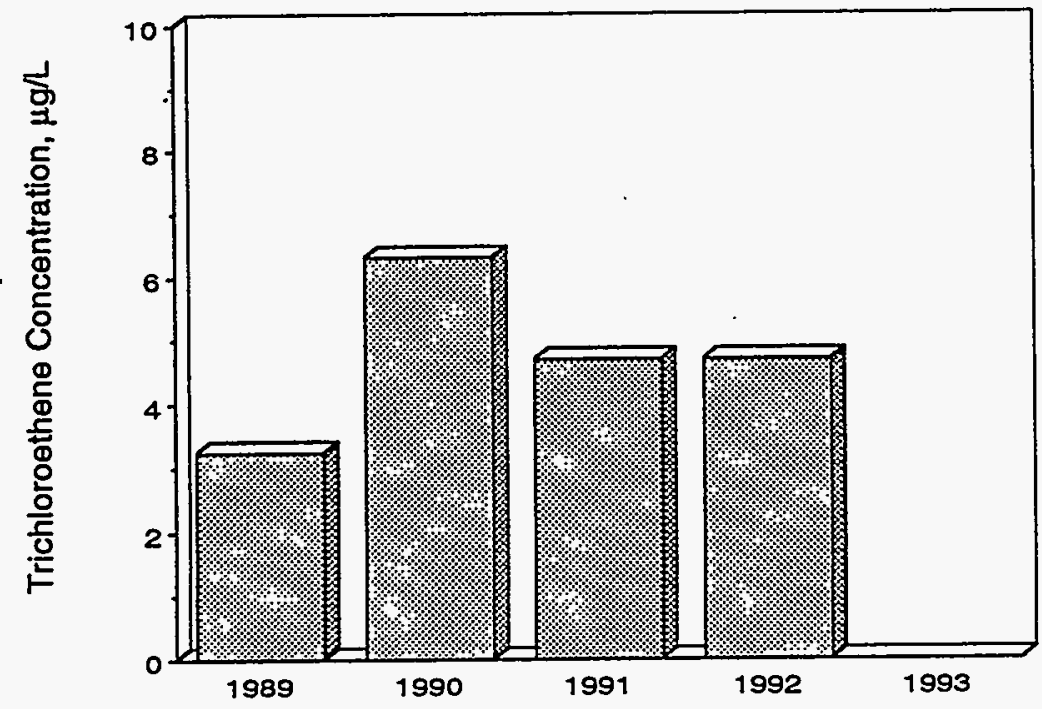


Groundwater Monitoring Program 


\section{Chapter 7}

\subsection{QUALITY ASSURANCE PROGRAMS FOR ENVIRONMENTAL DATA}

Mound participates in quality assurance (QA) exercises sponsored by the DOE and the EPA. Such exercises provide objective evaluations of the validity of the environmental data generated by Mound. In this Chapter, QA programs involving radiological and nonradiological analyses of a variety of environmental media are described. In addition to these external QA programs, Mound performs internal QA studies that make use of field and reagent blanks, internal standards, and duplicate samples.

\section{EML QA Program}

Twice each year, DOE's Environmental Measurements Laboratory (EML) conducts blind environmental sampling exercises for DOE sites. Each participating lab is given a number of samples to analyze for radiological constituents. The radionuclides are present as contaminants on air filters, or in soil, vegetation, or water. A laboratory's performance is evaluated by comparing their results with EML's reference values.

The concentrations reported by Mound for the March and September 1993 studies are shown in Table 7-1. The reference values established by EML are also shown in the Table. A useful method of evaluating Mound's performance is to. examine the ratio of Mound's result to the EML reference concentration for each environmental medium. This information is shown in Figure 71.

In 1993, EG\&G Mound performed 50 multiple analyses on four environmental media. As evidenced by Table 7-1 and Figure 7-1, 31 results were within $10 \%$ of the reference values, 11 were within $20 \%$, three were within $30 \%$, and one of the results exceeded the $50 \%$ range specified as "acceptable" by EML.

\section{NPDES QA Program}

National Pollutant Discharge Elimination System (NPDES) permits are used by the EPA to regulate discharges of liquid effluents. The permits limit the concentrations of certain wastewater constituents to protect the receiving body of water. To ensure that a facility does not exceed those limits, the NPDES permit imposes strict requirements for effluent characterization. The EPA requires that labs performing analyses for NPDES parameters participate in QA exercises. These exercises assure EPA that the labs are producing reliable and accurate data.

In 1993, as in previous years, Mound participated in the NPDES QA exercise. In this program, a contractor lab, Bionetics, prepares water samples forblind analysis. Labs, including Mound, analyze these samples and then submit the results to the contractor. The contractor evaluates the data based on limits for acceptability.

Mound's performance for 1993 is shown in Table 7-2. Of the 15 parameters analyzed, Mound was rated "acceptable" on 13. Two "check for error" messages were noted. The check for error messages were associated with slightly high results for cadmium and copper. A review of EG\&G Mound's analytical protocol did not reveal a systematic error, and, as seen in Table 7-2, the sample results were with the EPA's acceptance limits. 
Table 7-1. Mound DOE Quality Assessment Program Results for 1993: Radionuclides in Environmental Samples

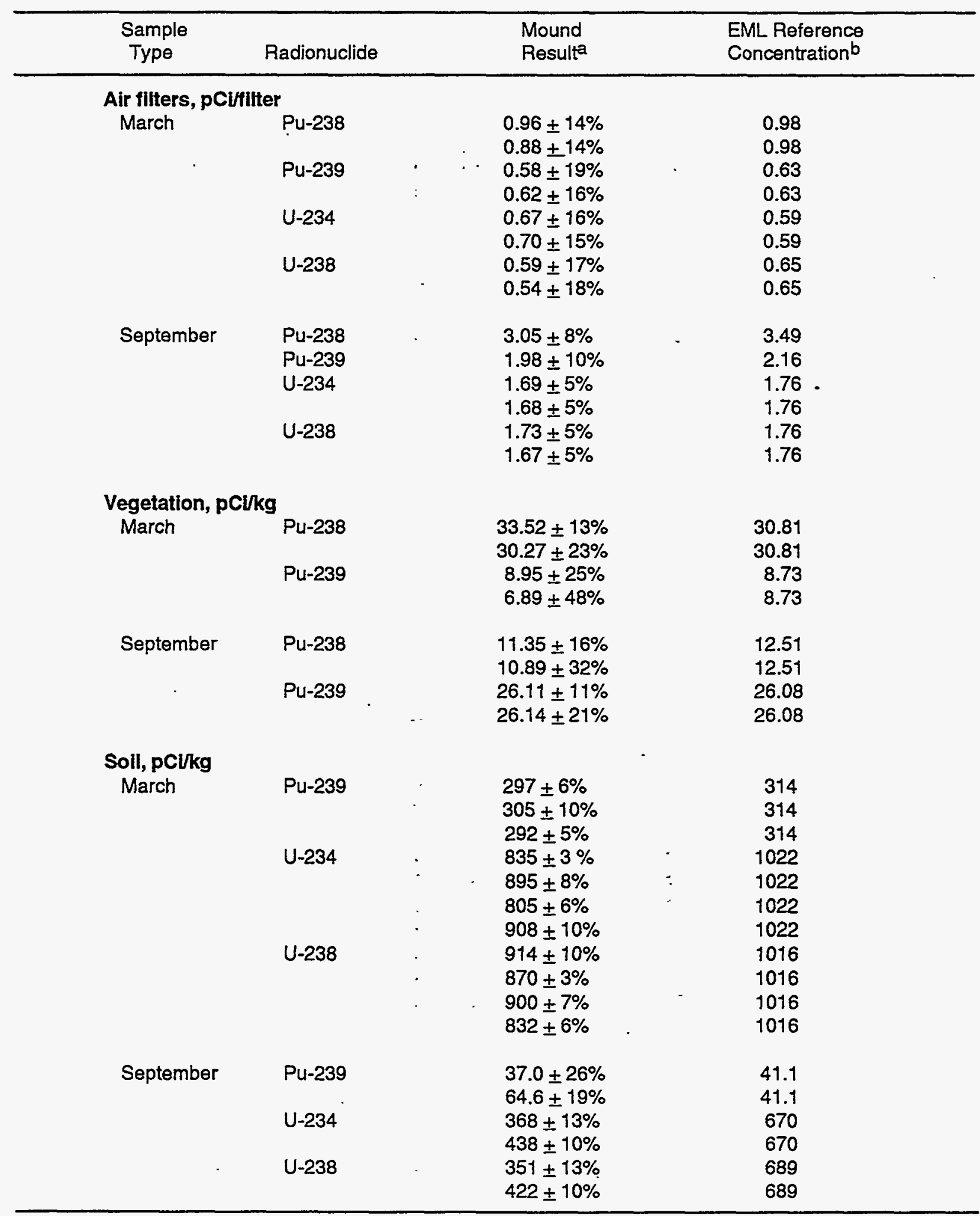


Table 7-1 (continued)

\begin{tabular}{clcc}
\hline $\begin{array}{c}\text { Sample } \\
\text { Type }\end{array}$ & Radionuclide & $\begin{array}{l}\text { Mound } \\
\text { Resulta }\end{array}$ & $\begin{array}{c}\text { EML Reference } \\
\text { Concentrationb }\end{array}$ \\
\hline Water, pCIL & & & \\
March & H-3 & $2425 \pm 10 \%$ & 2622 \\
& Pu-238 & $16.27 \pm 10 \%$ & 13.24 \\
& Pu-239 & $22.60 \pm 9 \%$ & 22.43 \\
& U-234 & $4.30 \pm 15 \%$ & 4.05 \\
& U-238 & $4.38 \pm 15 \%$ & 4.05 \\
September & H-3 & $7244 \pm 10 \%$ & 7298 \\
& & $7244 \pm 10 \%$ & 7298 \\
& Pu-238 & $9.19 \pm 8 \%$ & 9.14 \\
& Pu-239 & $29.46 \pm 4 \%$ & 30.81 \\
& $U-234$ & $27.84 \pm 4 \%$ & 28.65 \\
& U-238 & $28.11 \pm 4 \%$ & 29.19 \\
\hline
\end{tabular}

a The Mound error is the two-sigma error based on counting statistics or replicate analysis.

$b$ The EML error is the standard error of the mean.

Figure 7-1. Mound's Performance in the DOE Quality Assessment Program in 1993

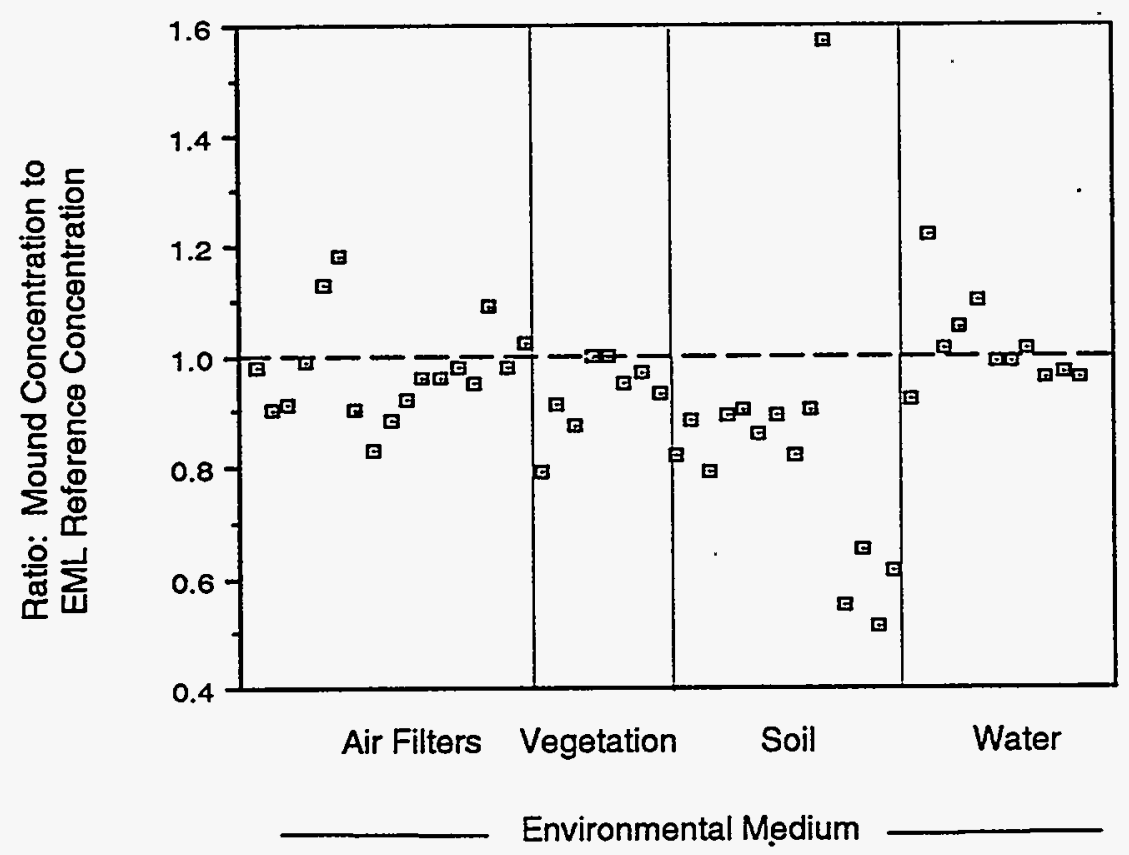


Table 7-2. Mound's Performance in the NPDES Quality Asssurance Program for 1993

\begin{tabular}{|c|c|c|c|c|c|}
\hline Parameters & $\begin{array}{l}\text { Mound } \\
\text { Value }\end{array}$ & $\begin{array}{r}\text { EPA } \\
\text { Value }\end{array}$ & $\begin{array}{l}\text { Acceptance } \\
\text { Limits }\end{array}$ & $\begin{array}{l}\text { Warning } \\
\text { Limits }\end{array}$ & $\begin{array}{l}\text { Mound } \\
\text { Performance } \\
\text { Evaluation }\end{array}$ \\
\hline \multicolumn{6}{|l|}{ Trace Metals, $\mu g \Omega$} \\
\hline Cadmium & 10 & 8.12 & $6.3-10.3$ & $6.8-9.79$ & Check for error \\
\hline Chromium & 70 & 62.0 & $49.2-73.7$ & $52.3-70.6$ & Acceptable \\
\hline Copper & 68 & 62.0 & $53.5-69.8$ & $55.6-67.8$ & Check for error \\
\hline Lead & 83 & 79.2 & $62.7-97.1$ & $67.0-92.8$ & Acceptable \\
\hline Mercury & $1.08^{\mathrm{a}}$ & 0.983 & $0.620-1.42$ & $0.719-1.32$ & Acceptable \\
\hline Nickel & 139 & 130 & $111-150$ & $116-145$ & Acceptable \\
\hline Zinc & 1134 & 1100 & $961-1220$ & $993-1190$ & Acceptable \\
\hline \multicolumn{6}{|l|}{$\begin{array}{l}\text { Miscellaneous } \\
\text { Analytes, mg } L\end{array}$} \\
\hline Total Suspended Solids & 40.3 & 43.2 & $34.7-45.2$ & $36.0-43.9$ & Acceptable \\
\hline Oil \& Grease & 14.2 & 15.0 & $8.13-19.4$ & $9.56-18.0$ & Acceptable \\
\hline Total Cyanide & 0.228 & 0.250 & $0.138-0.341$ & $0.164-0.316$ & Acceptable \\
\hline Total Residual Chlorine & 0.655 & 0.729 & $0.469-0.912$ & $0.528-0.853$ & Acceptable \\
\hline Ammonia as Nitrogen & 5.48 & 5.50 & $4.35-6.65$ & $4.62-6.37$ & Acceptable \\
\hline \multicolumn{6}{|l|}{ Demands, mg/L } \\
\hline$C B O D^{b}$ & 15.0 & 12.0 & $2.81-21.2$ & $5.34-18.7$ & Acceptable \\
\hline $\operatorname{COD}^{\mathrm{C}}$ & 24.0 & 21.8 & $12.6-30.5$ & $14.9-28.2$ & Acceptable \\
\hline pH (standard units) & 8.78 & 8.70 & $8.31-9.05$ & $8.40-8.96$ & Acceptable \\
\hline
\end{tabular}

a Mercury analysis performed for EG\&G Mound by a contract laboratory.

b $\mathrm{CBOD}=$ Carbonaceous biochemical oxygen demand.

c $C O D=$ Chemical oxygen demand. 


\section{Chapter 7}

Table 7-2 (continued)

\begin{tabular}{|c|c|c|c|c|}
\hline Parameters & $\begin{array}{c}\text { Contract } \\
\text { Lab } \\
\text { Valuea }\end{array}$ & $\begin{array}{l}\text { EPA } \\
\text { Value }\end{array}$ & $\begin{array}{l}\text { Acceptance } \\
\text { Limits }\end{array}$ & $\begin{array}{l}\text { Performance } \\
\text { Evaluation }\end{array}$ \\
\hline \multicolumn{5}{|c|}{$\begin{array}{l}\text { Blomonitoring Results, } \\
\% \text { of sample affected }\end{array}$} \\
\hline \multicolumn{5}{|c|}{$\begin{array}{l}\text { Pimephales promelas } \\
\text { (Fathead minnows) }\end{array}$} \\
\hline \multicolumn{5}{|c|}{ Acute Toxicity in MHSFb: } \\
\hline $\mathrm{LC}_{50} \mathrm{c}$ & 32.99 & 36.2 & $2.33-70.0$ & Acceptable \\
\hline \multicolumn{5}{|c|}{ Chronic Toxicity: } \\
\hline \multicolumn{5}{|c|}{ Survival in MHSF } \\
\hline NOEC $d$ & 17.68 & 25.0 & $12.5-50.0$ & Acceptable \\
\hline \multicolumn{5}{|c|}{ Growth effects in MHSF } \\
\hline $1 C^{e}$ & 13.28 & 33.9 & $3.47-64.3$ & Acceptable \\
\hline NOEC & 8.84 & 25.0 & $12.5-50.0$ & Not Acceptable \\
\hline \multicolumn{5}{|c|}{$\begin{array}{l}\text { Ceriodaphnia dubia } \\
\text { (Water fleas) }\end{array}$} \\
\hline \multicolumn{5}{|c|}{ Acute Toxicity in DMWf: } \\
\hline$L_{5} C^{c}$ & 19.61 & 22.6 & $D L 9-45.4$ & Acceptable \\
\hline \multicolumn{5}{|c|}{ Chronic Toxicity: } \\
\hline \multicolumn{5}{|c|}{ Sunival in DMW } \\
\hline NOEC & 17.67 & 50.0 & $25.0-100$ & Not Acceptable \\
\hline \multicolumn{5}{|c|}{ Growth effects in DMW } \\
\hline $1 C^{\theta}$ & 21.76 & 27.9 & DL-56.1 & Acceptable \\
\hline NOEC & 17.67 & 25.0 & $12.5-50.0$ & Acceptable \\
\hline
\end{tabular}

a Biomonitoring studies are performed for EG\&G Mound by a contract laboratory.

b MHSF = moderately hard synthetic freshwater.

$c_{L} C_{50}=$ lethal concentration to $50 \%$ of the population.

$d$ NOEC $=$ no observable effect concentration.

$I C=$ inhibition concentration.

$f_{\mathrm{DMW}}=$ diluted mineral water.

$9 \mathrm{DL}=$ detection limit. 


\section{Quality Assurance Programs for Environmental Data}

Table 7-2 also shows an evaluation of the contract lib used to perform biomonitoring studies for EG\&G Mound. The lab's performance for the 1993 QA exercise resulted in six "acceptable" and two "not acceptable" ratings. As a consequence of the "not acceptable" results, the laboratory was required to submit a letter of explanation to EG\&G Mound; the letter was reviewed and forwarded to the EPA. In the letter, the laboratory outlined the steps taken to minimize the possibility of future "not acceptable" scores.

\section{APG QA Program}

As a companion to the EPA program described above, Mound also participates in another QA exercise for NPDES parameters. In this study, water samples prepared by Analytical Products Group, Inc. (APG) are analyzed in a round-robin fashion by participating labs. The studies are conducted two times per year. For each parameter of interest, APG determines the average value reported by all participants. The figure-of-merit used to evaluate a lab is the standard deviation of a result from the average for that parameter. In this fashion, a lab's performance is rated relative to the performance of all other labs.

Limits of acceptability are associated with the APG studies. There are "warning" and "not acceptable limits" for performance. Thoselimits have been set at 1.96 and 2.58 standard deviations from the average, respectively.

Mound participated in both APG studies for 1993. The results are shown in Figures 7-2a and 7-2b for trace metals and miscellaneous parameters, respectively.
Figure 7-2a demonstrates that Mound's performance for trace metal analysis in 1993 was exceptional. All standard deviations from the averages were small and no performance limits were exceeded. Mound's performance for the miscellaneous analytes, Figure 7-2b, was generally satisfactory. One data point, however, does lie outside the desirable range. The protocol associated with the analyte in question was reviewed; no systematic errors were detected.

\section{Mound Internal QA Program}

In addition to the external programs described above, Mound performs a number of internal QA operations. Blank samples are analyzed to verify the absence of excessive instrument contamination or background. The standard deviation of the blank is then used to calculate the lower limit of detection. A quality-based approach to these data is imperative because many of the environmental samples analyzed at Mound have contaminant concentrations at or below the lower detection limit.

Mound also routinely uses duplicate sample analysis and internal standard techniques to evaluate analytical precision. Deviation from an expected value results in a comprehensive review of the analytical protocol. 
Figure 7-2a. Mound's Performance in the APG Proficiency Environmental Testing Program for 1993: Trace Metal Analysis

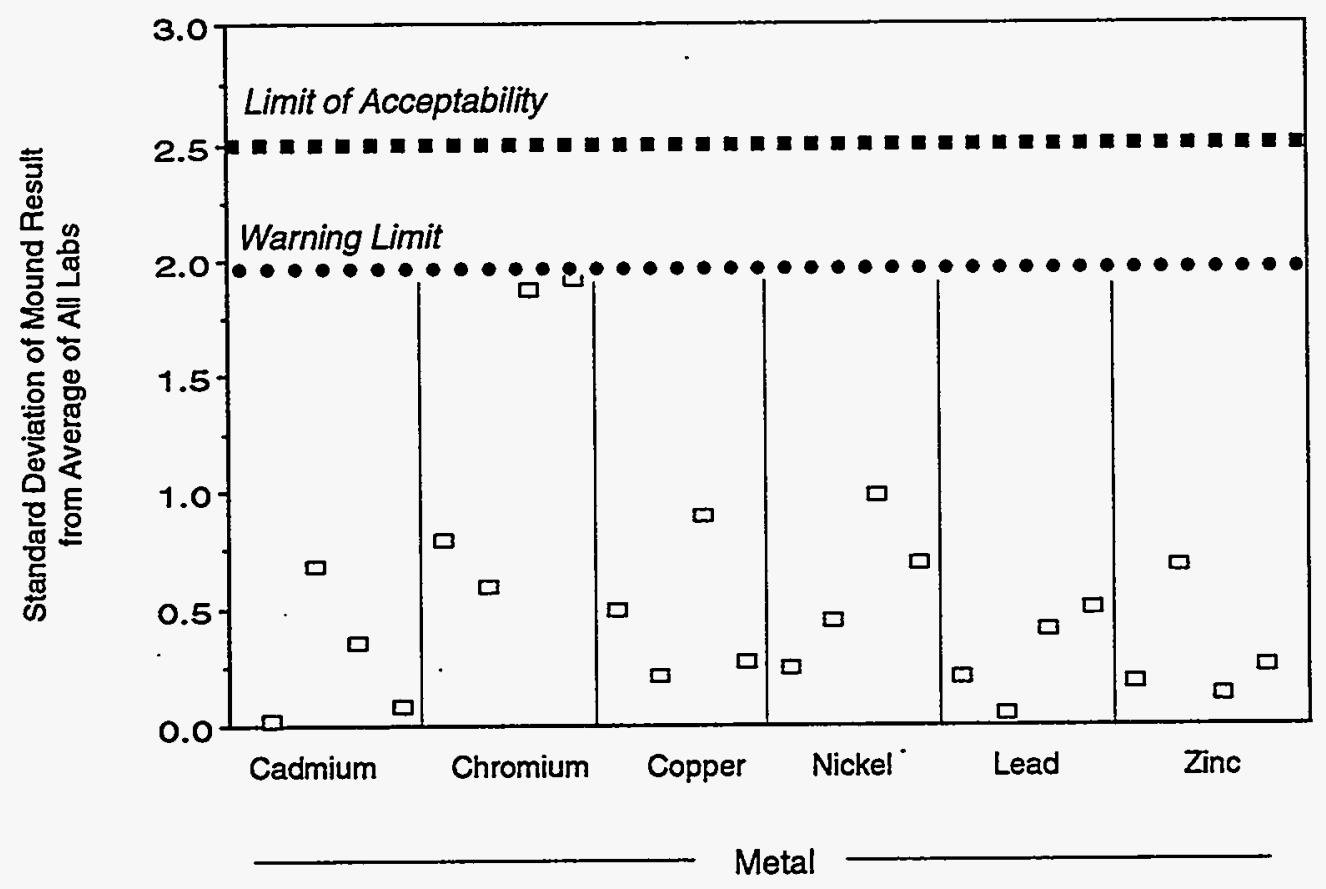


Figure 7-2b. Mound's Performance in the APG Proficiency Environmental Testing Program for 1993: Miscellaneous Parameters

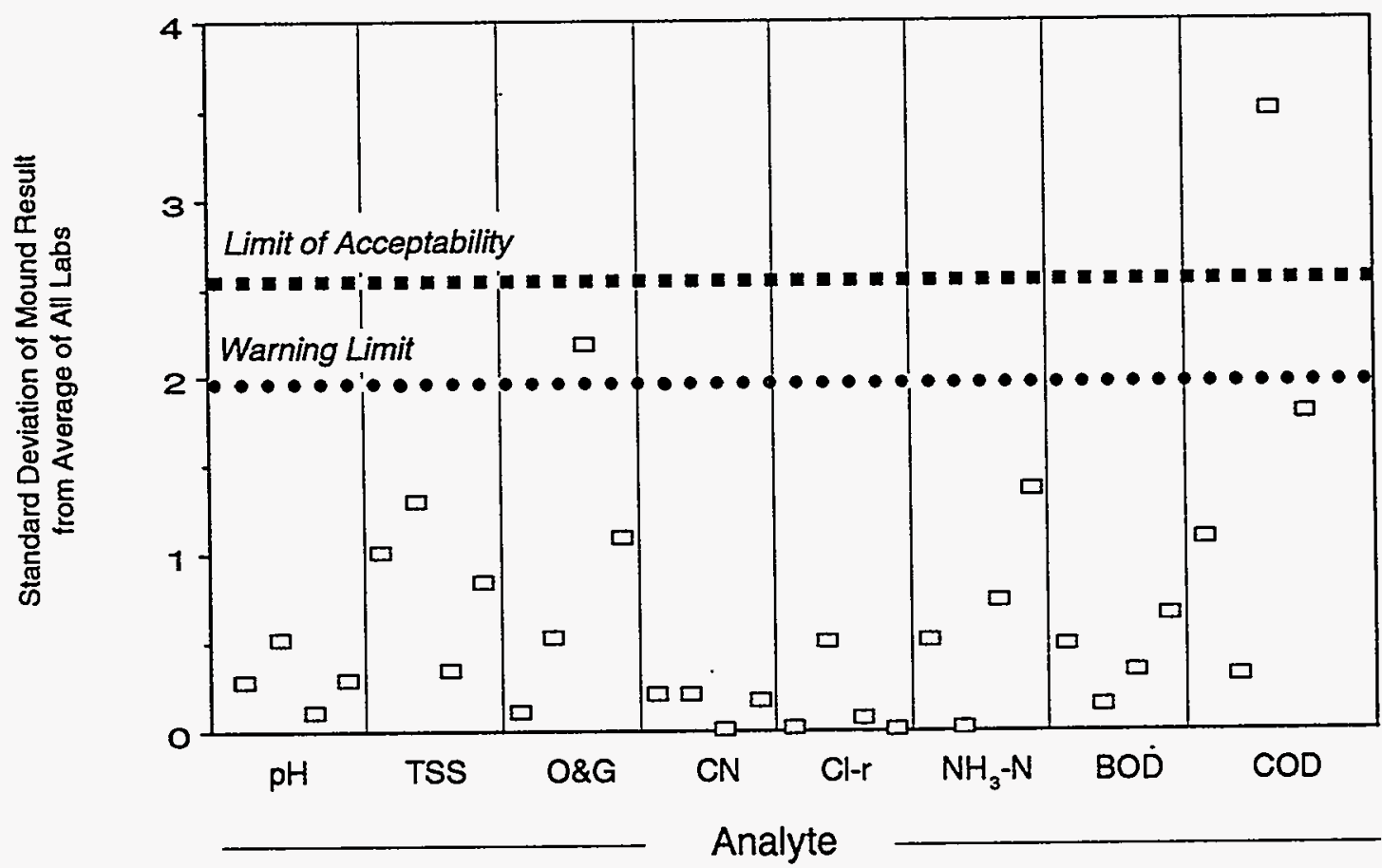

$\therefore$

\begin{tabular}{ll|}
\hline \multicolumn{2}{c}{ LEGEND } \\
\hline TSS = Total Suspended Solids & $\mathrm{NH}_{3}-\mathrm{N}=$ Ammonia as Nitrogen \\
O\&G = Oil and Grease & $\mathrm{BOD}=$ Biological Oxygen Demand \\
$C N=$ Cyanide & $\mathrm{COD}=$ Chemical Oxygen Demand \\
$\mathrm{Cl}-\mathrm{r}=$ Residual Chlorine &
\end{tabular}




\subsection{REFERENCES}

DOE(U.S. Department of Energy) 1987. Mound Installation Generic Monitoring Plant/Site Specific Information, Albuquerque Operations Office, Albuquerque, New Mexico.

DOE(U.S. Department of Energy) 1990. General Environmental Protection Program, DOE Order 5400.1, U.S. Department of Energy, Washington, D.C.

DOE (U.S. Department of Energy) 1991. EnvironmentalRegulatory Guidefor Radiological Effluent Monitoring and Environmental Surveillance, DOE/EH-0173T, U.S. Department of Energy, Washington, D.C.

DOE (U.S. Department of Energy) 1992. DOE Methodsfor Evaluating Environmental and Waste Management Samples, DOE/EM-0089T, U.S. Department of Energy, Washington, D.C.

DOE (U.S. Department of Energy) 1993. Radiation Protection of the Public and the Environment, DOE Order 5400.5, U.S. Department of Energy, Washington, D.C.

DOE (U.S. Department of Energy) 1993a. OU-9 Residential Well/Cistern Survey Task Summary, Mound Plant, Miamisburg, OH.

DOE (U.S. Department of Energy) 1993b. Groundwater Protection Management Program Plan, Mound.Plant, Miamisburg, $\mathrm{OH}$.

DOE (U.S. Department of Energy) 1994. Operable Unit 1 Remedial Investigation Report, Mound Plant, Miamisburg, Ohio, Albuquerque Operations Office and the Environmental Restoration Program, EG\&G Mound Applied Technologies.
EG\&G Mound (EG\&G Mound Applied Technologies) 1991. Hydrogeologic/ Groundwater Contamination, Operable Uint 1 , Area B Technical Memorandum, Mound Plant, Miamisburg, $\mathrm{OH}$.

EG\&G Mound (EG\&G Mound Applied Technologies) 1994. Environmental Monitoring Plan for Mound, Mound Plant, Miamisburg, $\mathrm{OH}$.

EPA (U.S. Environmental Protection Agency) 1985. AP-42: Compilation of Air Pollutant Emission Factors, 4th ed., U.S. Environmental Protection Agency, Research Triangle Park, NC.

ICRP (International Commission on Radiological Protection) 1977. Recommendations of the International Commission on Radiological Protection, ICRP Publication No. 26.

ICRP (International Commission on Radiological Protection) 1979. Limits for Intakes by Workers, ICRP Publication No. 30.

NCRP(National Council on Radiation Protection and Measurements) 1987. Ionizing Radiation Exposure of the Population of the U.S., NCRP Report No. 93, Bethesda, MD.

Sheehan, W.E., Curtis, M.L., and Carter, D.C. 1975. Development of a Low-Cost Versatile Method for Measurement of HTO and HT in Air, Report MLM-2205, Mound Plant, Miamisburg, $\mathrm{OH}$.

10 CFR 1021. Compliance with the National Environmental Policy Act. . 


\subsection{REFERENCES (Continued)}

40 CFR 61, Subpart H. National Emission Standards for Emissions of Radionuclides Other Than Radon From Department of Energy Facilities.

40 CFR 141-143. National Primary Drinking Water Regulations Implementation and National Secondary Drinking Water Regulations.

OAC 3745-17-10. Restrictions on Particulate Emissions from Fuel Burning Equipment.

OAC3745-18-63. Montgomery County Emission Limits.

OAC 3745-95. Backflow Prevention and CrossConnection Control. 


\section{APPENDIX}

\section{A.1 Exposure Routes}

Members of the public receive radiation doses via various exposure pathways. For radionuclides discharged to the atmosphere, a person may inhale or be immersed in airborne radionuclides. Other routes of airborne exposure include ground deposition of radionuclides and consumption of food products that were contaminated by airborne releases. For radionuclides released to water, a person may consume contaminated water or fish. The otherpotential water-based exposure pathways (e.g., swimming and boating) generally do not add significantly to the dose.

\section{A.2 Dose Calculations Based on Measured Data}

For DOE reporting requirements, doses are presented as 50-year committed effective dose equivalents (CEDEs). The CEDE is the total dose equivalent that will be received by an individual over a 50-year time period as a result of one year of exposure to ionizing radiation. The total CEDE reported is the sum of the CEDEs from the air, water, and food-related pathways.

Each year, Mound personnel calculate CEDEs for tritium, plutonium-238, plutonium-239. (Other radionuclides released by Mound were present in concentrations that were below environmental levels or were too small to affect the overall dose.) The CEDEs for tritium and plutonium are evaluated using environmental monitoring data measured on and near the plant site. A CEDE for a given radionuclide is calculated as shown below. Specific input values for 1993 are shown in Table A-1.

$$
\mathrm{CEDE}=\sum_{1}^{\mathrm{p}} \mathrm{C}_{\mathrm{r}} \cdot \mathrm{I}_{\mathrm{a}} \cdot \mathrm{DCF} \cdot \mathrm{CF}
$$

where $\mathrm{CEDE}=$ total committed effective dose equivalent, mrem

$$
\begin{aligned}
\sum_{1}^{\mathrm{p}} & =\text { summation over the exposure pathways } 1 \text { through } \mathrm{p} \\
\mathrm{C}_{\mathrm{r}} & =\text { maximum average concentration of the radionuclide } \\
\mathrm{I}_{\mathrm{a}} & =\text { annual intake of the environmental medium } \\
\mathrm{DCF} & =\text { dose conversion factor for the radionuclide and intake type } \\
\mathrm{CF} & =\text { conversion factor to accommodate dose conversion factor units }
\end{aligned}
$$

The CEDE for all radionuclides are then summed to provide a single value for reporting purposes. 
Table A-1. Factors Used to Calculate 1993 CEDEs

\begin{tabular}{|c|c|c|c|}
\hline Radionuclide & $\begin{array}{l}\text { Maximum Average } \\
\text { Concentration }\end{array}$ & Location & $\begin{array}{l}\text { Dose Conversion } \\
\text { Factor, mrem } / \mu \mathrm{Ci}(\mathrm{a})\end{array}$ \\
\hline $\begin{array}{l}\text { Tritium } \\
\text { Air } \\
\text { Well water } \\
\text { Produce }\end{array}$ & $\begin{array}{c}6.76 \times 10^{-12} \mu \mathrm{Ci} / \mathrm{mL} \\
0.88 \times 10^{-6} \mu \mathrm{Ci} / \mathrm{mL} \\
0.22 \times 10^{-6} \mu \mathrm{Ci} / \mathrm{g}\end{array}$ & $\begin{array}{c}211 \\
0904 \\
\text { Miamisburg }\end{array}$ & $\begin{array}{l}6.3 \times 10^{-8}(b) \\
6.3 \times 10^{-8} \\
6.3 \times 10^{-8}\end{array}$ \\
\hline $\begin{array}{l}\text { Plutonium-238 } \\
\text { Air } \\
\text { Well water } \\
\text { Produce } \\
\text { Fish }\end{array}$ & $\begin{array}{c}41.45 \times 10^{-18} \mu \mathrm{Ci} / \mathrm{mL} \\
\text { environmental level } \\
0.14 \times 10^{-9} \mu \mathrm{Cig} \\
\text { environmental level }\end{array}$ & $\begin{array}{l}\text { 213R } \\
\text { Miamisburg } \\
\text { Miamisburg } \\
\text { Great Miami River }\end{array}$ & $\begin{array}{l}0.38 \\
\text { N/A - no dose } \\
0.0019 \\
\text { N/A - no dose }\end{array}$ \\
\hline $\begin{array}{l}\text { Plutonium-239 } \\
\text { Air } \\
\text { Well water } \\
\text { Produce } \\
\text { Fish }\end{array}$ & $\begin{array}{c}1.33 \times 10^{-18} \mu \mathrm{Ci} / \mathrm{mL} \\
\text { environmental level } \\
0.015 \times 10^{-9} \mu \mathrm{Ci} / \mathrm{g} \\
0.008 \times 10^{-9} \mu \mathrm{Ci} / \mathrm{g}\end{array}$ & $\begin{array}{l}213 R \\
\text { Miamisburg } \\
\text { Miamisburg } \\
\text { Great Miami River }\end{array}$ & $\begin{array}{l}0.42 \\
N / A \text { - no dose } \\
0.0022 \\
0.0022\end{array}$ \\
\hline
\end{tabular}

Annual Intake Values

$\begin{array}{llll}\text { Air } & 8400 \mathrm{~m}^{3} & \text { Produce } & 260 \mathrm{~kg} \\ \text { Well water } & 730 \mathrm{~L} & \text { Fish } & 21 \mathrm{~kg}\end{array}$

(a) Plutonium releases from Mound are believed to be insoluble (Class $Y$ ). However, to provide a reasonable degree of conservatism in the dose estimates, the $\mathrm{Pu}-238$ and $\mathrm{Pu}-239$ doses factors used are averages of Class $W$ and Class $Y$ values.

(b) The dose factor is multiplied by a factor of 1.5 to include absorption of tritium through the skin. 


\section{A-3. Dose Calculations for NESHAPs Compliance}

To demonstrate compliance with the requirements of the National Emission Standards for Hazardous Air Pollutants (NESHAPs, 40 CFR 61, Subpart $\mathrm{H})$, Mound performs additional dose calculations each year for all airborne releases. As preferred by the EPA in 40 CFR 61, Subpart H, Mound uses the computer code CAP- 88 to calculate those doses.
Whenever available, Mound uses site-specific data as input to the code. Meteorological data measured onsite are used to evaluate transport and dispersion. Stack-specific release rates are used in an aggregated form as shown below (Table A-2). This approach makes it possible to combine stacks with similar physical attributes. Table A-2 lists the relevant stack information used for the 1993 CAP-88 runs.

Table A-2. 1993 CAP-88 Input Data

\begin{tabular}{|c|c|c|c|c|c|}
\hline $\begin{array}{l}\text { Stack } \\
\text { IDs }\end{array}$ & $\begin{array}{l}\text { Assumed } \\
\text { Stack } \\
\text { Height } \\
\text { (meters) }\end{array}$ & $\begin{array}{l}\text { Assumed } \\
\text { Stack } \\
\text { Diameter } \\
\text { (meters) }\end{array}$ & $\begin{array}{c}\text { Exit } \\
\text { Velocity } \\
\text { (meters/sec) }\end{array}$ & Radionuclide(s) & $\begin{array}{l}1993 \\
\text { Release } \\
\text { (Ci/yr) }\end{array}$ \\
\hline $\mathrm{HH}$ & 48 & 1.7 & 1.2 & $\mathrm{H}-3$ & $1.64 \times 10^{1}$ \\
\hline $\begin{array}{l}\text { NCPDF/ } \\
\text { SW1C }\end{array}$ & 42 & 0.8 & 15.2 & $\begin{array}{l}H-3 \\
\text { Pu-238 } \\
\text { Pu-239 } \\
\text { U-234 } \\
U-238\end{array}$ & $\begin{array}{l}4.84 \times 10^{-1} \\
3.16 \times 10^{-8} \\
1.42 \times 10^{-9} \\
2.51 \times 10^{-9} \\
3.15 \times 10^{-10}\end{array}$ \\
\hline HEFS & 45 & 2.0 & 12.0 & $\begin{array}{l}\mathrm{H}-3 \\
\text { Pu-238 } \\
\text { Pu-239 }\end{array}$ & $\begin{array}{l}5.80 \times 10^{2} \\
5.61 \times 10^{-8} \\
4.26 \times 10^{-9}\end{array}$ \\
\hline $\begin{array}{l}\text { SMPPI } \\
\text { TWESTI } \\
\text { TEAST }\end{array}$ & 60 & 2.0 & 10.4 & $\begin{array}{l}H-3 \\
\text { Pu-238 } \\
\text { Pu-239 } \\
U-234 \\
U-238\end{array}$ & $\begin{array}{l}1.96 \times 10^{-1} \\
8.86 \times 10^{-6} \\
2.64 \times 10^{-8} \\
6.03 \times 10^{-8} \\
5.63 \times 10^{-8}\end{array}$ \\
\hline $\begin{array}{l}\text { WDALR/ } \\
\text { WDAHR/ } \\
\text { WDSS }\end{array}$ & 16 & 0.6 & 6.8 & $\begin{array}{l}H-3 \\
\text { Pu-238 } \\
\text { Pu-239 }\end{array}$ & $\begin{array}{l}3.00 \times 10^{-2} \\
3.27 \times 10^{-6} \\
8.20 \times 10^{-9}\end{array}$ \\
\hline
\end{tabular}




\section{EXTERNAL}

\section{OSTI}

\section{U.S. Department of Energy}

\section{DOE/Headquarters}

Ralph A. Hagan, Site Action Team Leader, DP-642

Richard D. Hahn, Director, DP-64

Barry Daniel, Director, PA-1

Michael H. Kleinrock, Director, EM-22

Kathleen I. Taimi, Director, EH-22 (5)

Ralph Lightner, Director, EM-45

John P. Sand, EM-453

Rear Admiral Winford G. Ellis, USN, Deputy Assistant Secretary for Military Applications, DP-20

DOE/Albuquerque

Constance L. Soden, Director, EPD (3)

Charles P. Demos, Classification Officer, CIPS

Paul Mann, Mound Installation Manager, ERPO

\section{DQE/Ohio Field Office}

John A. Jones, Deputy Chief Counsel

Susan L. Smiley, Environmental Engineer
DOE/Miamisburg Area Office

Larry D. Kirkman, Director

W.C. Sherard, Jr., Deputy Director

Oba L. Vincent, Associate Director, Environmental Management

Dewain V. Eckman, Associate Director, Safety, Operations, and Technical Support

Michael A. Reker, Environmental Team Leader

Art W. Kleinrath, Project Engineer, Team Leader

James O. Johnson, Environmental Compliance

Debra A. White, Environmental Compliance

Catherine W. Skapik, D\&D Engineer

\section{DOE Contractors}

W.J. Bair, Manager

Life Sciences Center

Battelle Pacific Northwest Lab

Dianna Cirrincione

Environmental Protection \& Waste Reprocessing EG\&G Rocky Flats

Gretchen Gallegos

Lawrence Livermore National Lab

Norbert Golchert

Environment and Waste Management Program ES\&H Department

Argonne National Lab

Ken Hargis, Group Leader

Environmental Surveillance

Los Alamos National Lab 
Eva Eckert Hickey

Battelle Pacific Northwest Lab

Hue-Su A. Hwang

Sandia National Lab

J.R. Naidu, Section Head

Environmental Protection

Brookhaven National Lab

James G. Rogers, Coordinator

Environmental Protection Activities

Martin-Marietta Energy Systems

Rodger Woodruff

Environmental Sciences Department

Batelle Pacific.Northwest Lab

EG\&G, Inc.

W.H. Parker, III, Director

Environmental Programs

\section{State and Federal Officials}

The Honorable John Glenn

U.S. Senator

The Honorable Howard Metzenbaum

U.S. Senator

The Honorable Tony.Hall

U.S. Representative

The Honorable John Boehner

U.S. Representative

The Honorable David Hobson

U.S. Representative

The Honorable Ted Strickland

U.S. Representative

The Honorable Charles Horn

Ohio Senator
The Honorable Donald Mottley

Ohio Representative

The Honorable Rhione McLin

Ohio Representative

The Honorable Tom Roberts

Ohio Representative

The Honorable Jeff Jacobsen

Ohio Representative

The Honorable George Voinovich

Governor

The Honorable Michael DeWine

Lt. Governor

The Honorable Lee Fisher

Attorney General

U.S. Environmental Protection Agency (U.S. EPA)

EPA Region V. Chicago, IL

Jack Barnette, Chief

Radiation and Indoor Air Section

Steven Goranson, Chief

Environmental Monitoring Branch

EPA Eastern District Office

John Gierczak, Environmental Engineer

Agency for Toxic Substances and Disease

Control

Bill Taylor

State of Ohio EPA (OEPA)

QEPA Columbus

Donald Schregardus, Director 
Bob Hodanbosi, Chief

Air Pollution Control

Gary Martin, Acting Chief

Surface Water

John Sadzewicz, Chief

Drinking and Ground Waters

Southwest District Office

Tom Winston, Director

Other State of Ohio Agencies

Kenneth B. Cole, Chief

Technology Branch

Emergency Management Agency

County, City and Township Offices

The Honorable Dick Church, Mayor

City of Miamisburg

John Weithofer, City Manager

City of Miamisburg

Hazel Eisele, Councilwoman

City of Miamisburg

Andy Alford, Councilman

City of Miamisburg

Bill Fuller, Councilman

City of Miamisburg

Paul Gutshall, Councilman

City of Miamisburg

Dan Kirchner, Councilman

City of Miamisburg

Mady Ransdell, Councilwoman

City of Miamisburg

Dave Wood, Councilman

City of Miamisburg
William Forbes, Law Director

City of Miamisburg

Mike Grauwelman, Transition Manager

City of Miamisburg

Shirley Omietanski, Trustee President

Miami Township

Berman Layer, Trustee

Miami Township

Doug Zink, Trustee

Miami Township

James Foster, Zoning Administrator

Miami Township

Donald Vermillion, Administrator

Montgomery County

Charles Curran, Commissioner

Montgomery County

Donald Lucas, Commissioner

Montgomery County

Donna Moon, Commissioner

Montgomery County

Gerald Paprocki

SW Ohio Economic Development

Nora Lake

Miami Valley Regional Planning Commission

Phil Parker, President

Dayton Chamber of Commerce

Carl Berg, Superintendent

Miamisburg City Schools

John Maletta, Member

Miamisburg Board of Education 
Kathleen Bates, Member

Miamisburg Board of Education

Joseph Omietanski, Member

Miamisburg Board of Education

Cindy Treiber, Member

Miamisburg Board of Education

Judith Peterson, Member

Miamisburg Board of Education

Mike McCabe, Business Manager

Miamisburg City Schools

\section{Media}

Lori Wesbter

WKEF-TV

Mark Casey

WHIO-TV

Rob Meenie

WDTN-TV

Darrel Gray

WMMX Radio

Joyce Herring

WDAO Radio

Jim Barrett

WHIO Radio

Kim Faris

WING Radio

Charles Vansant

WLQT Radio

Bob Montgomery

WYMJ Radio
Steve Watson

WONE/WTUE Radio

Bill Nance

WFCJ Radio

Rica Duffuss

WROU Radio

Jim Pickering

Miamisburg News

Jim Hanna

Associated Press

John Brinkman

Dayton Daily News

Tim Gaffney

Dayton Daily News

Greg Stricharchuk

Dayton Daily News

Gene Fox

Dayton Business Reporter

Gabrielle Jacobs

The Business News

Steve Schelb

Small Business News

\section{Stackeholders}

Frank Winslow

Edward Howard \& Co.

Dan Brower

Brower Enterprises Inc.

Velma Shearer

Neighbors in.Need 
James Lucas

Dayton Citizens for Global Security

India Clarke

Sierra Club

Dan Grove

Mound Citizen's Action Group

Sharon Cowdrey

Miamisburg Environment, Safety and Health

Jodi Lally

Boston University School of Public Health

Peter Townsend

Hydro-Log

John Applegate

Fernald Citizen's Task Force

Gary Nolley, President

Oil, Chemical and Atomic Worker's Union

Charles Williams, President

United Plant Guard Workers of America

INTERNAL

EG\&G Mound Applied Technologies

M.L. Alexander

B.D. Barton

: L.R. Bauer (10)

M.C. Becker (50)

R.A. Benson

R.J. Brewer

D.G. Carfagno

J.L. Clark

S.A. Cloud

W.P. Davis

D.G. Draper

B.M. Farmer (50)

C.L. Fellers
P.E. Figgins

R.J. Finney

J.P. Fontaine

C.S. Friedman

T.J. Hamilton

J.R. Hausfeld

L.C. Hopkins

S.L. Howard

M.P. Isper

R.R. Jaeger

V.S. Johnson

K.G. Koehler

G.V. Macievic

P.O. Matthews

P.A. Parker

R.P. Paulick

C.A. Phillips

J.K. Puckett

B.K. Pugh

D.A. Rakel

L.L. Roush

R.S. Tunning

J.H. Walton

S.L. Waskey

M.A. Williams

M.G. Wilson

J.D. Yonko

Publications

Technical Resource Center 